\title{
CRISTIANI BALDO
}

\section{Mecanismos envolvidos na ação hemorrágica de metaloproteinases de venenos de serpentes}

Tese apresentada ao Programa de PósGraduação Interunidades em Biotecnologia USP/Instituto Butantan/ IPT, para obtenção do título de Doutor em Biotecnologia.

São Paulo 


\section{CRISTIANI BALDO}

\section{Mecanismos envolvidos na ação hemorrágica de metaloproteinases de venenos de serpentes}

Tese apresentada ao Programa de Pós Graduação Interunidades em Biotecnologia USP/Instituto Butantan/IPT, para obtenção do título de Doutor em Biotecnologia.

Área de concentração: Biotecnologia

Orientadora: Dra. Ana Maria Moura da Silva

São Paulo

2009 
DADOS DE CATALOGAÇÃO NA PUBLICAÇÃO (CIP)

Serviço de Biblioteca e Informação Biomédica do Instituto de Ciências Biomédicas da Universidade de São Paulo

(C) reprodução total

Baldo, Cristiani.

Mecanismos envolvidos na ação hemorrágica de metaloproteinases de venenos de serpentes / Cristiani Baldo. -- São Paulo, 2009.

Orientador: Ana Maria Moura da Silva.

Tese (Doutorado) - Universidade de São Paulo. Instituto de Ciências Biomédicas. Programa de Pós-Graduação Interunidades em

Biotecnologia USP/IPT/Instituto Butantan. Área de concentração:

Biotecnologia. Linha de pesquisa: Farmacologia Bioquímica e Molecular.

Versão do título para o inglês: Mechanisms involved in the hemorrhage induced by snake venom metalloproteinases .

Descritores: 1. Veneno de serpentes 2. Metaloproteinases 3. Jararagina 4. Hemorragia 5. Colágeno I. Silva, Ana Maria Moura da II. Universidade de São Paulo. Instituto de Ciências Biomédicas.

Programa de Pós-Graduação em Biotecnologia III. Título. 


\section{UNIVERSIDADE DE SÃO PAULO \\ Programa de Pós-Graduação Interunidades em Biotecnologia}

Universidade de São Paulo, Instituto Butantan, Instituto de Pesquisas Tecnológicas

Canditado (a): $\quad$ Cristiani Baldo.

Título da Tese: $\quad$ Mecanismos envolvidos na ação hemorrágica de metaloproteinases de venenos de serpentes.

Orientador (a): $\quad$ Ana Maria Moura da Silva.

A comissão Julgadora dos trabalhos de Defesa da Tese de Doutorado, em sessão pública realizada a ......... ................, considerou

( )Aprovado (a) ( ) Reprovado (a)

Examinador (a): Assinatura:

Nome:

Instituição:

Examinador (a): Assinatura:

Nome:

Instituição:

Examinador (a): Assinatura:

Nome:

Instituição:

Examinador (a): Assinatura:

Nome:

Instituição:

Presidente: Assinatura:

Nome:

Instituição: 


\section{CERTIFICADO}

Certificamos que o Protocolo para uso de animais em experimentação $n^{\circ}$ 191/04, sobre o projeto intitulado "Distribuição tecidual e ação local em tecido endotelial e muscular da jararagina e neuwiedase, representantes das SVMPs classes PI e PIII", sob a responsabilidade de Ana Maria Moura da Silva está de acordo com os Princípios Éticos na Experimentação Animal adotado pelo Colégio Brasileiro (COBEA) e foi aprovado pela COMISSÃO DE ÉTICA NO USO DE ANIMAIS DO INSTITUTO BUTANTAN (CEUAIB) em reunião de 15/02/2005.

São Paulo, 28 de fevereiro de 2005.

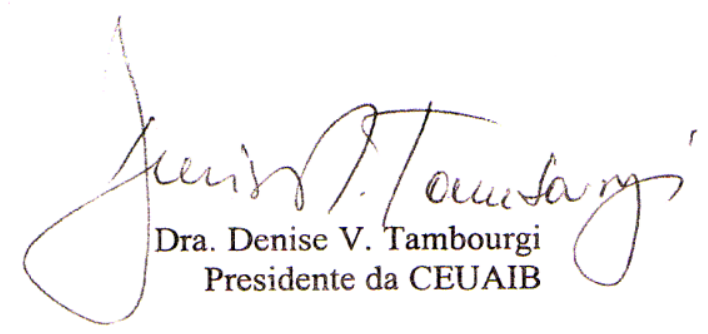


Dedico este trabalho às pessoas mais importantes da minha vida:

Ao meu amor, Sérgio, que coloriu minha vida tornando todos os meus sonhos realidade. Lindo, obrigada pelo amor, carinho, cumplicidade, confiança e por estar sempre ao meu lado em todos os momentos. P.S: I Love You

Aos meus pais, Luzia e Delci, exemplos de dignidade e coragem. Obrigada pelo apoio incondicional e por estarem sempre presentes durante todos os momentos da minha vida. Amo vocês!

Às minhas queridas irmãs Alininha e Eliane, pelo carinho, cumplicidade e amizade, e pelo apoio incondicional em todos os momentos. Amo vocês! 


\section{AGRADECIMENTOS}

À Dra. Ana Moura, minha querida orientadora, exemplo de profissional durante toda minha formação acadêmica. Agradeço pela orientação, confiança e apoio presentes em todas as etapas deste trabalho, especialmente durante os momentos mais difíceis. Obrigada pelo carinho, amizade e compreensão que te tornam muito mais do que uma grande pesquisadora, mas uma pessoa muito especial.

Ao Dr. Colin Jamora, da University of California- San Diego, e todo seu grupo de pesquisa, pela oportunidade de crescimento inigualável e por ter me ensinado os primeiros passos do mundo maravilhoso da imunofluorescência.

À querida Dra. Telma Zorn e todos os alunos do Laboratório de Biologia da Matriz Extracelular, do ICB/USP, por me acolher em seu laboratório com muito carinho e atenção e tornar possível a realização de experimentos fundamentais para a conclusão deste trabalho.

Ao Dr. Gustavo Amarantes Mendes e ao Dr. Ricardo Weinlich do Laboratório de Biologia Celular e Molecular do ICB/USP, pelo auxílio nos ensaios de citometria de fluxo.

Ao Dr. Richard H. Valente, do Laboratório de Toxinologia-FIOCRUZ, pela realização dos experimentos de espectrometria de massas.

À Dra. Isabel Batista e ao Dr. Ivo Lebrun do Laboratório de Bioquímica e Biofísica do Instituto Butantan, pelo auxílio nos experimentos de caracterização estrutural das tox isoladas.

À Dra. Norma Yamanouye do Laboratório de Farmacologia do Instituto Butantan, pelas valiosas discussões e passeios inesquecíveis por San Diego.

À Dra. Isabelle Tanjoni, pela grande ajuda no início do meu doutorado. 
À Dra. Patrícia Bianca Clissa, do Laboratório de Imunopatologia do Instituto Butantan, minha primeira colaboradora no Butantan. Paty obrigada pelo carinho e atenção, pelas HUVECs e por solucionar (quase) todos os problemas do laboratório!

À Dra. Maísa Esplendore Della-Casa do Laboratório de Imunopatologia do Instituto Butantan, pelas valiosas discussões e auxílio durante esse longo período. Querida Má, obrigada pelo amor, carinho, respeito e companheirismo que sempre estiveram presentes desde nosso primeiro encontro.

À Dra. Veridiana Rodrigues de Melo da Universidade Federal de Uberlândia, minha orientadora no mestrado, pela amizade, carinho e apoio incondicional.

À Dra. Eliana Faquim do Laboratório de Imunopatologia do Instituto Butantan, não apenas pela leitura crítica desde trabalho, mas por seu carinho e atenção durante todo meu doutorado.

À todos os pesquisadores e alunos do laboratório de Imunopatologia, Geraldo, Irene, Kátia, Marisa, Amanda, Juliana, Sandriana, Isa, Iara, Renata, Bruna, Priscila, Tiago, Juninho, Caio, Gabriela, Podé, Louise, Bianca, Miguel, Tamires por toda ajuda e agradável convivência.

À Cleusa M. Raspantini Pellegrini, técnica do Departamento de Biologia Celular e do Desenvolvimento/ICB-USP, pela grande ajuda nos cortes histológicos e por sua disposição em ajudar sempre.

Ao Alexsander Seixas de Souza, técnico do Microscópio Confocal do Instituto Butantan, pela ajuda na captura das imagens e pelos momentos de descontração durante as longas horas de análise.

À todos os funcionários do Laboratório de Imunopatologia por sempre estarem dispostos em ajudar.

Às minhas queridas amigas Daiana e Stella. Meninas, obrigada por me agüentarem em jornada dupla (casa e lab). Agradeço muito pelo amor, carinho, cumplicidade, festinhas, 
comidinhas (muitas!!), comprinhas, paciência e compreensão. Agradeço também a Ariane, que chegou faz pouco tempo, mas é como se sempre estivesse presente.

À minha querida amiga Carla, pela cumplicidade e amor que nos mantém sempre unidas.

Aos meus queridos amigos de Araguari, Cleber, Flavinha, Ana Paula, Victor, Renata, Luciano, Miro e Cíntia, que mesmo de longe sempre estiveram presente nesta longa caminhada. Em especial, a nossa querida amiga Rosana, que foi exemplo de determinação e dignidade.

À FAPESP e CNPq pelo apoio financeiro. 
"It's the possibility of having a dream come true that makes life interesting.

The Alchemist- Paulo Coelho 
Este projeto foi realizado no Laboratório de Imunopatologia do Instituto Butantan, com auxílio financeiro da Fundação de Amparo à Pesquisa do Estado de São Paulo-FAPESP Processo n: 04/13672-8. 


\section{RESUMO}

BALDO, C. Mecanismos envolvidos na ação hemorrágica de metaloproteinases de venenos de serpentes. 2009. 150 f. Tese (Doutorado em Biotecnologia)- Programa de PósGraduação Interunidades em Biotecnologia USP/Instituto Butantan/IPT, São Paulo, 2009.

A ação hemorrágica decorrente do envenenamento botrópico está associada à ação das metaloproteinases de veneno de serpentes (SVMPs) no endotélio vascular. Esse efeito é atribuído à ação catalítica das SVMPs, uma vez que agentes quelantes inibem completamente essa atividade. Contudo, a hemorragia é potencializada nas SVMPs da classe P-III, que contêm adicionalmente os domínios tipo-disintegrina e rico em cisteínas, sugerindo a participação de propriedades não catalíticas na expressão da atividade hemorrágica. Neste sentido, o objetivo desse trabalho foi comparar a ação da jararagina, toxina hemorrágica da classe P-III isolada do veneno de B. jararaca, e da BnP1, SVMP da classe P-I fracamente hemorrágica isolada do veneno de $B$. neuwiedi, quanto a degradação e afinidade à proteínas plasmáticas e de matriz extracelular e ação em células endoteliais, em modelos in vitro, e, em modelos ex vivo, a biodistribuição da toxina e subseqüentes alterações na matriz extracelular e endotélio, utilizando a pele de camundongos como modelo experimental. Inicialmente a BnP1 foi isolada do veneno de B. neuwiedi e caracterizada como uma nova toxina da classe P-I das SVMPs. A BnP1 e a jararagina hidrolisaram de forma semelhante as proteínas de matriz extracelular e a jararagina mostrou maior eficiência na degradação da fibrina e do fibrinogênio. Nos experimentos de ligação em fase sólida, a jararagina e a BnP1 comportaram-se de maneira semelhante frente ao fibrinogênio e laminina, mas apenas a jararagina e a jarararagina-C (domínios tipo disintegrina e rico em cisteínas) se ligaram com alta afinidade ao colágeno tipo I e IV. Em HUVECs, a jararagina e BnP1 induziram a redução da viabilidade celular, principalmente por apoptose, com profundas alterações no citoesqueleto de actina, de maneira dependente da atividade catalítica. Entretanto, em modelo de pele, a comparação entre jararagina e $\mathrm{BnP} 1$ revelou diferenças significativas: em doses equimolares, apenas a jararagina induziu intensa hemorragia, acompanhada de degradação do colágeno fibrilar na região da hipoderme e do colágeno IV presente na membrana basal dos vasos sangüíneos. A jararagina e jararagina-C localizaram-se na parede dos vasos sangüíneos havendo co-localização da jararagina com o colágeno IV presente na membrana basal de 
capilares e vênulas. Os resultados obtidos neste trabalho nos permitiram concluir que a ligação ao colágeno está envolvida na atividade hemorrágica das SVMPs. Esta ligação ocorre através do domínio tipo-disintegrina e promove o acúmulo das toxinas nas proximidades dos vasos sanguíneos, tornando assim a catálise dos componentes da membrana basal mais eficiente. Diferentemente do que ocorre com as SVMPs da classe P-I, a localização tecidual das SVMPs da classe P-III contribuiria para a atividade hemorrágica observada nessas toxinas. Conjuntamente, esses dados revelam um novo mecanismo de ação de SVMPs hemorrágicas, ainda não descrito na literatura, que explica as diferenças na ação hemorrágica das SVMPs das classes P-I e P-III.

Palavras-chave: Veneno de serpentes. Metaloproteinases. Jararagina. Hemorragia. Colágeno. 


\begin{abstract}
BALDO, C. Mechanisms involved in the hemorrhage induced by snake venom metalloproteinases. 2009. $150 \mathrm{f}$. PhD thesis (Biotechnology)- Programa de Pós-Graduação Interunidades em Biotecnologia USP/Instituto Butantan/IPT, São Paulo, 2009.
\end{abstract}

The hemorrhage observed after bites by Bothrops snakes is related to the action of the snake venom metalloproteinases (SVMPs) in the vascular endothelium. This effect is due to their catalytic activity, since it is completely inhibited by quelant agents. Nevertheless, hemorrhagic activity is higher in SVMPs from P-III class which contains additionally the disintegrin-like and cysteine-rich domains, suggesting a role of non-catalytic domains in the expression of hemorrhagic activity. In this way, the aim of this work was to compare the action of jararhagin, a highly hemorrhagic P-III SVMP isolated from $B$. jararaca venom, and BnP1, a weakly hemorrhagic P-I SVMP isolated from B. neuwiedi venom in in vivo assays as degradation and affinity to plasmatic and extracellular matrix proteins and action on endothelial cells, or ex vivo experiments as toxin distribution in tissues and subsequent alterations in extracellular matrix and endothelium, using mouse skin as experimental model. Initially, BnP1 was isolated from the B. neuwiedi venom and characterized as a new P-I SVMP. BnP1 and jararhagin equally affected extracellular matrix proteins but jararhagin was more efficient to degrade fibrin and fibrinogen. In solid phase assay, jararhagin and BnP1 did not bind to fibrinogen and laminin. Only jararhagin and jararhagin- $\mathrm{C}$ (disintegrin-like and cysteine-rich domains) bond with high affinity to collagen I and IV. In HUVECs, jararhagin and $\mathrm{BnP} 1$ induced the reduction of the cell viability by apoptosis, with marked alterations in F-actin cytoskeleton. These effects were dependent on their catalytic activity. However, in skin model the comparison between jararhagin and BnP1 showed significant differences: using the same molar doses, only jararhagin induced intense hemorrhage with degradation of the fibrillar collagen in hypodermis region and collagen IV from basement membrane; jararhagin and jararhagin-C concentrated in blood vessels walls, such as capillaries and venules and jararhagin co-localized with blood vessel basement membrane collagen IV. The results obtained in this work suggest that the collagen binding is related to the hemorrhagic activity of SVMPs. This binding occurs by the disintegrin-like domain and promotes the accumulation of the toxin near to the blood vessels, making the catalysis of the basement 
membrane components more efficient, and resulting in the strong hemorrhagic activity of PIII SVMPs. This study shows a new mechanism of hemorrhagic action of SVMPs that, for the first time, explains the differences between P-I and P-III SVMPs.

Key words: Snake venom. Metalloproteinases. Jararhagin. Hemorrhage. Collagen. 


\section{LISTA DE ILUSTRAÇOES}

Figura 1. Representação esquemática da estrutura do sítio ativo das metaloproteinases da família das metzincinas 29

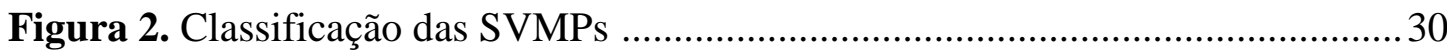

Figura 3. Representação esquemática da pele e de seus anexos ...............................40

Figura 4. Representação esquemática da formação das membranas basais ...............43

Figura 5. Purificação da jararagina e jararagina-C em sistema FPLC.........................66

Figura 6. Purificação da BnP1 e BnP2 em sistema FPLC ..........................................69

Figura 7. Alinhamento das seqüências da BnP1 e BnP2 com outras SVMPs...........70

Figura 8. Comparação da atividade hemorrágica da jararagina e $\mathrm{BnP} 1$......................72

Figura 9. Atividade miotóxica da jararagina e BnP1 ................................................. 73

Figura 10. Efeitos da jararagina e BnP1 na viabilidade e adesão de HUVECs e $\mathrm{C} 2 \mathrm{C} 12$

Figura 11. Apoptose e citotoxicidade induzidas pela jararagina e BnP1 em cultura

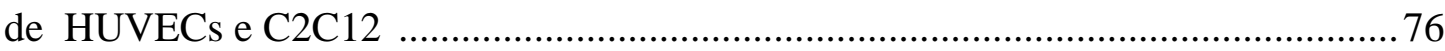

Figura 12. Efeito da jararagina e BnP1 no citoesqueleto de HUVECs ..................... 78

Figura 13. Ação da jararagina e BnP1, cataliticamente inativadas, no citoesqueleto de HUVECs

Figura 14. Comparação da atividade fibrinolítica da jararagina e BnP1 em placa de fibrina-agarose

Figura 15. Perfil de degradação do fibrinogênio humano pela jararagina

e BnP1 81

Figura 16. Perfil de degradação da laminina pela jararagina e BnP1 82

Figura 17. Interação das SVMPs à componentes plasmáticos e de matriz extracelular .83

Figura 18. Região estrutural envolvida na ligação da jararagina ao colágeno ............ 84

Figura 19. Interação da jararagina com o colágeno I desnaturado ............................. 85

Figura 20. Atividade hemorrágica da jararagina complexada ao colágeno................. 86

Figura 21. Atividade fibrinolítica da jararagina complexada ao colágeno .................8 87

Figura 22. Ação da jararagina e BnP1 na pele do dorso de camundongos..................89 
Figura 23. Análise histológica de cortes de $5 \mu \mathrm{m}$ da pele do dorso de camundongos BALB/c após 15 minutos da injeção intradérmica de jararagina $(10 \mu \mathrm{g})$ e $\mathrm{BnP} 1(5 \mu \mathrm{g}$ e $50 \mu \mathrm{g})$

Figura 24. Biodistribuição das SVMPs conjugadas com Alexa488 na pele de camundongos

Figura 25. Biodistribuição das SVMPs conjugadas com Alexa488 no tecido muscular 93

Figura 26. Cinética da distribuição da jararagina conjugada com Alexa488 na pele de camundongos

Figura 27. Cinética da distribuição da jararagina conjugada com Alexa488 no tecido muscular 95

Figura 28. Co-localização da jararagina com o colágeno IV ...................................96

Figura 29. Ação da jararagina e $\mathrm{BnP} 1$ na matriz de colágeno fibrilar .........................99

Figura 30. Efeitos da jararagina e BnP1 na distribuição do colágeno IV ................. 100

Figura 31. Efeitos da jararagina e BnP1 na distribuição da laminina ..................... 101

Figura 32. Mecanismo de indução da atividade hemorrágica pelas SVMPs da classe P-III 


\section{LISTA DE TABELAS}

Tabela 1. Atividade fibrinolítica das frações do veneno de B. neuwiedi obtidas da cromatografia em gel filtração 68 


\section{LISTA DE ABREVIATURAS E SIGLAS}

ADAMs (A Disintegrin and Metalloproteinase)- Disintegrina/Metaloproteinase ADP- Adenosina Difosfato

BCIP- (5-Bromo-4-Chloro-3'-Indolyphosphate p-Toluidine Salt)

bFGF (basic Fibroblast Growth Factor) -Fator de crescimento de fibroblastos básico

BnP1-Alexa88- BnP1 conjugada com Alexa488

BSA (Bovine Serum Albumin)- Soro Albumina Bovina

cDNA (complementary Deoxyribonucleic Acid)- Ácido desoxirribonucléico complementar CK - creatina quinase

COBEA- Colégio Brasileiro de Experimentação animal

CXCL1 (Chemokine-C-X-C-motif-ligand 1)- CXC quimiocina ligante 1

CXCL2 (Chemokine-C-X-C-motif-ligand 2) - CXC quimiocina ligante 2

CXCL8 (Chemokine-C-X-C-motif-ligand 8)- CXC quimiocina ligante 8

DAPI (4',6-amino-2phenuylindole, dihydrochloride)

DMSO- Dimetilsulfóxido

DNA (Deoxyribonucleic Acid)- Ácido desoxirribonucléico

EDTA- Ácido etilenodiamino tetracético

EGF (endothelial growth factor)- Fator de crescimento endotelial

ELISA (Enzyme-linked immunosorbent assay)- Ensaio de imuno-absorção por ligação enzimática

F-actina- Fibras de actina

FAK (Focal Adhesion Kinase)- Quinase de adesão focal

FPLC (Fast protein liquid chromatography)- Cromatografia líquida de alta resolução

GP Ib-IX-V- Glicoproteína Ib-IX-V

GPIb- glicoproteína Ib

* No texto as siglas estão representadas pela combinação das letras iniciais das sequiências de palavras que constitui um nome referente a língua inglesa. Desta forma, a sigla DNA (inglês) foi mantida ao invés da sigla ADA (português). Para facilitar a leitura do texto, as palavras constituintes das siglas foram citadas em inglês e somente nesta listas as palavras relacionadas às siglas foram traduzidas para o português. 
HEPES- (N-2-hydroxyethylpiperzine-N1-2-ethanesulfonic acid)

HF3 (Hemorrhagic Factor 3)- Fator hemorrágico 3

HU-USP- Hospital Universitário da Universidade de São Paulo

HUVECs (Human Umbilical Vein Endothelial Cells)- Cultura primária de células endoteliais de cordões umbilicais humanos

IgG- Imunoglobulina $\mathrm{G}$

IL-1 $\beta$ - Interleucina $-1 \beta$

IL6- Interleucina-6

IL-8- Interleucina-8

Jar- Jararagina

Jar-Alexa88- Jararagina conjugada com Alexa488

JarC- Jararagina C

JarC-Alexa88- Jararagina C conjugada com Alexa488

LDH- Lactato desidrogenase

MB- Membranas Basais

MEC- Matriz Extracelular

MMP-9 (matrix metalloproteinase 9)- Metaloproteinase de matriz extracelular 9

MMPs (matrix metalloproteinases)- Metaloproteinases de matriz extracelular

MTT- (3-(4,5-dimethylthiazol-2-yl)-2,5 diphenyl tetrazolium bromide)

NBT-Nitro-Blue Tetrazolium Chloride

OCT -Optimal cutting temperature

OPD- o-Fenilenodiamina

PBS (Phosphate Buffered Saline)- Salina tamponada com fosfato

PRP- Plasma rico em plaquetas

RNA (Ribonucleic Acid)- Ácido ribonucléico

SDS (Sodium Dodecyl Sulfate)- Dodecil Sulfato de Sódio

SDS-PAGE- Eletroforese em gel de poliacrilamida na presença de SDS

SVMPs (Snake Venom Metalloproteinases) - Metaloproteinases de venenos de serpentes

TACE (TNF- $\alpha$ converting enzyme )- Enzima conversora de TNF- $\alpha$

TNFR1 (Tumor Necrosis Factor- $\alpha$ Receptor 1)- Receptor do TNF- $\alpha 1$

TNFR2 (Tumor Necrosis Factor- $\alpha$ Receptor 2)- Receptor do TNF- $\alpha 2$

TNF- $\alpha$ (Tumor Necrosis Factor- $\alpha$ )- Fator de necrose tumoral alfa

Tris- hidroximetil-aminometano 
TRITC- (Tetramethyl Rhodamine Isothiocyanate)

VEGF (Vascular Endothelial Growth Factor)- Fator de crescimento endotelial vascular VWF (Von Willenbrand Factor)- Fator de Von Willenbrand

NC Non Collagenous domains- Domínios não colágenos 


\section{LISTA DE SÍMBOLOS}

\section{Aminoácidos}

$\begin{array}{lll}\text { A } & \text { Ala } & \text { Alanina } \\ \text { C } & \text { Cys } & \text { Cisteína } \\ \text { D } & \text { Asp } & \text { Ácido Aspártico } \\ \text { E } & \text { Glu } & \text { Ácido Glutâmico } \\ \text { F } & \text { Phe } & \text { Fenilalanina } \\ \text { G } & \text { Gly } & \text { Glicina } \\ \text { H } & \text { Hys } & \text { Histidina } \\ \text { I } & \text { Ile } & \text { Isoleucina } \\ \text { K } & \text { Lys } & \text { Lisina } \\ \text { L } & \text { Leu } & \text { Leucina } \\ \text { M } & \text { Met } & \text { Metionina } \\ \text { N } & \text { Asn } & \text { Asparagina } \\ \text { P } & \text { Pro } & \text { Prolina } \\ \text { Q } & \text { Gln } & \text { Glutamina } \\ \text { R } & \text { Arg } & \text { Arginina } \\ \text { S } & \text { Ser } & \text { Serina } \\ \text { T } & \text { Thr } & \text { Treonina } \\ \text { V } & \text { Val } & \text { Valina } \\ \text { W } & \text { Trp } & \text { Triptofano } \\ \text { Y } & \text { Try } & \text { Tirosina } \\ & & \end{array}$




\section{SUMÁRIO}

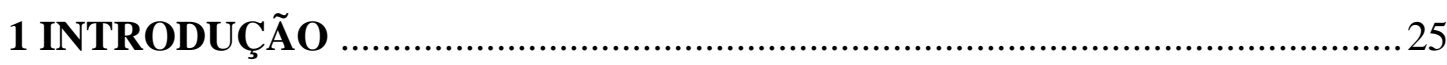

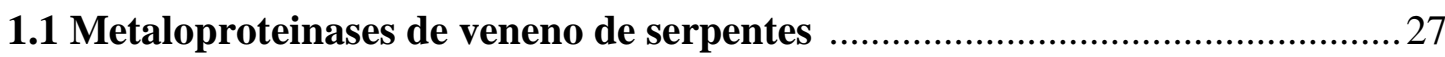

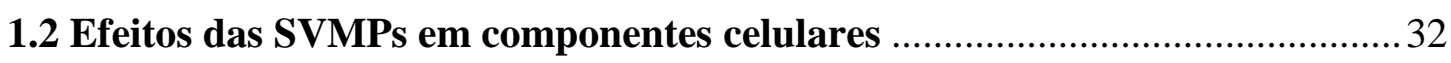

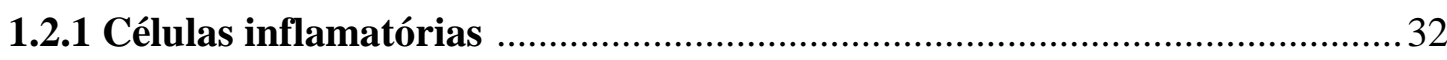

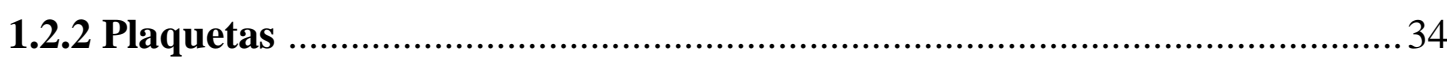

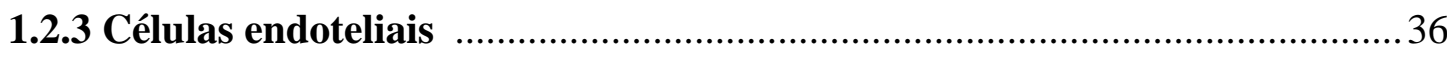

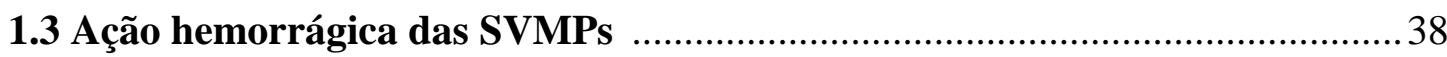

1.3.1 Modelo ex vivo para estudo da hemorragia induzida pelas SVMPs ............39

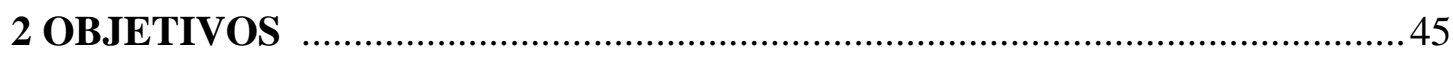

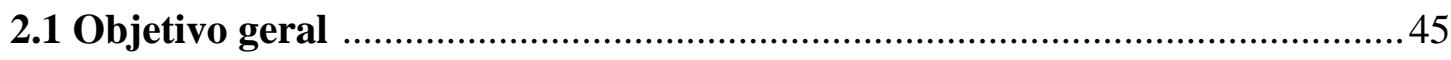

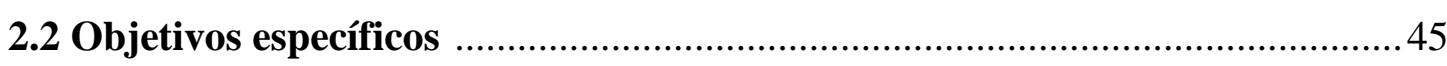

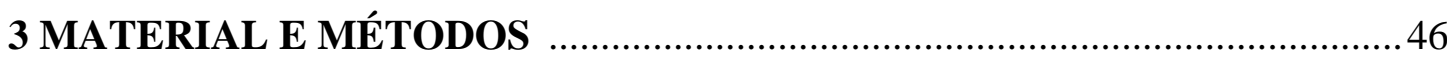

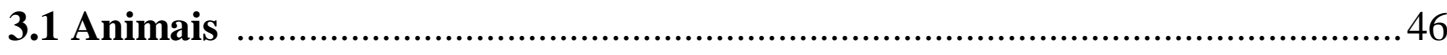

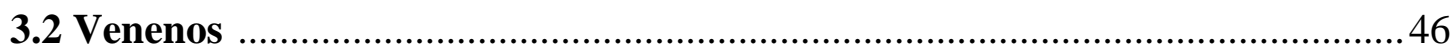

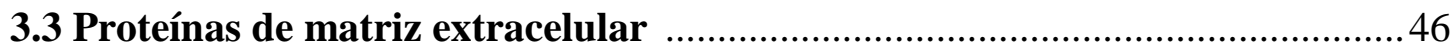

3.4 Anticorpos e sondas para imunofluorescência .................................................47

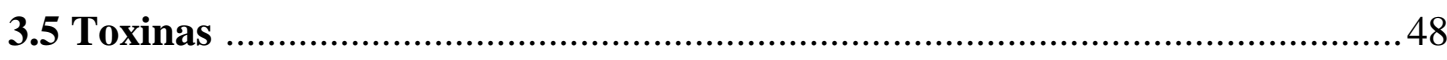

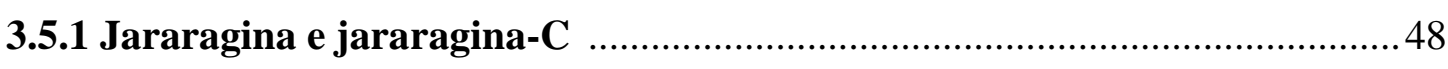

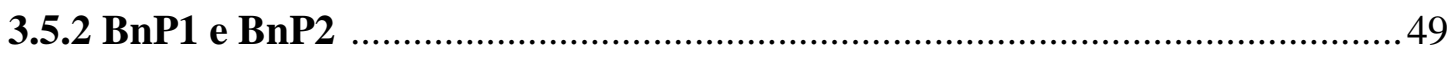

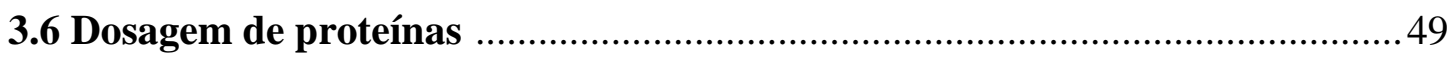

3.7 Eletroforese em gel de poliacrilamida em condições desnaturantes

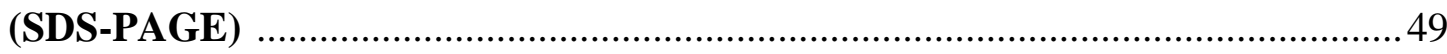

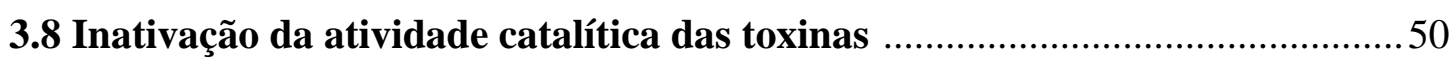

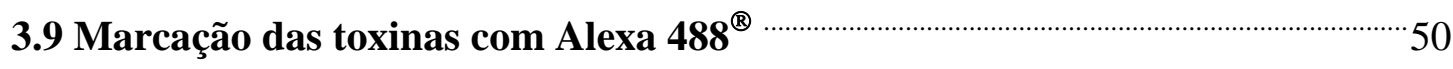

3.10 Seqüenciamento das proteínas isoladas ...................................................51

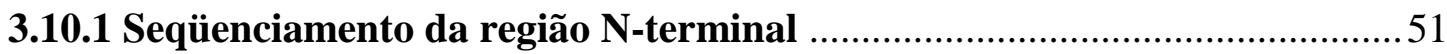

3.10.2 Análise por espectrometria de massas .................................................... 51

3.11 Inibição da agregação plaquetária ........................................................52

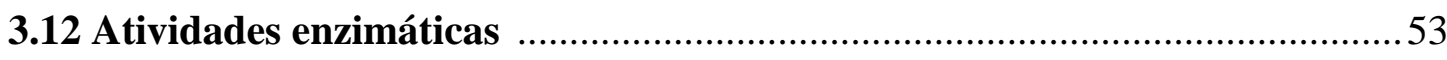


3.12.1 Atividade proteolítica em placa de fibrina-agarose .53

3.12.2 Atividade proteolítica em substratos solúveis ............................................5

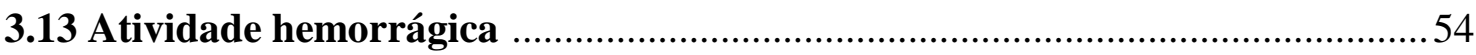

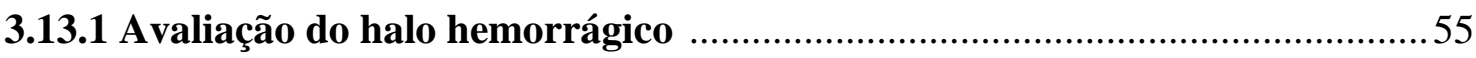

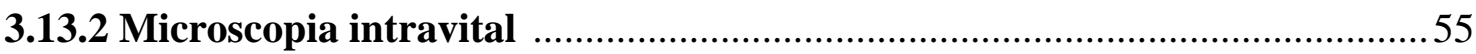

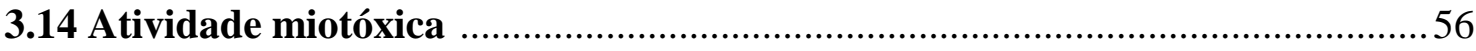

3.15 Ação em cultura de células endoteliais e musculares ....................................56

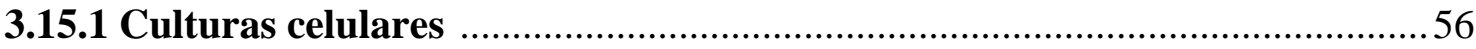

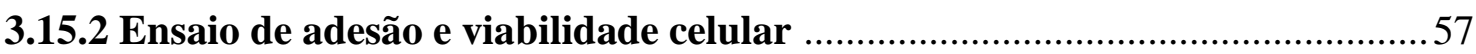

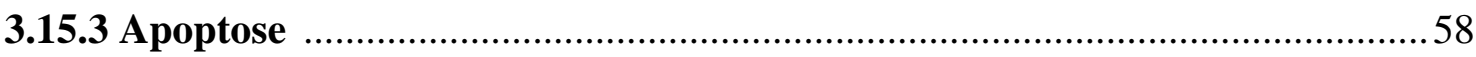

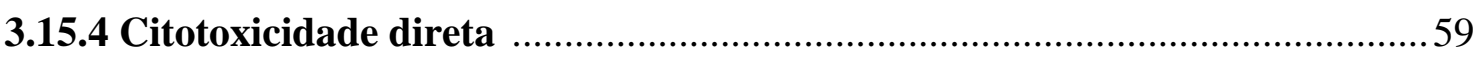

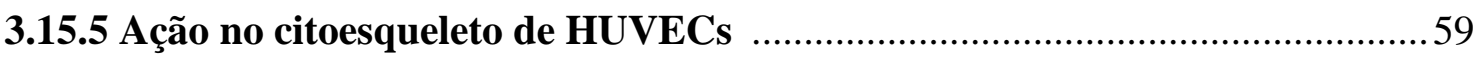

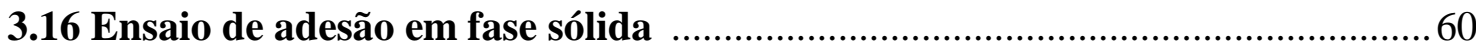

3.17 Atividades biológicas da jararagina complexada com o colágeno ..................61

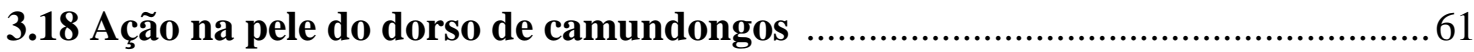

3.18.1 Coleta e processamento do material para microscopia de luz .....................62 62

3.18.2 Histoquímica para detecção de colágenos fibrilares ....................................62

3.18.3 Biodistribuição das SVMPs e co-localização com o colágeno IV .................6 63

3.18.4 Detecção dos componentes da membrana basal ..........................................63

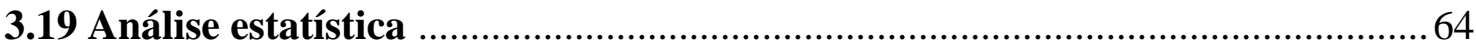

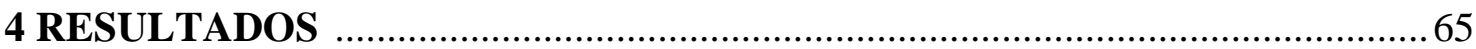

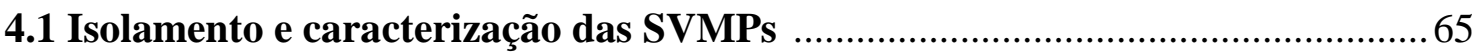

4.1.1 Isolamento da jararagina, uma SVMP da classe P-III, do veneno de

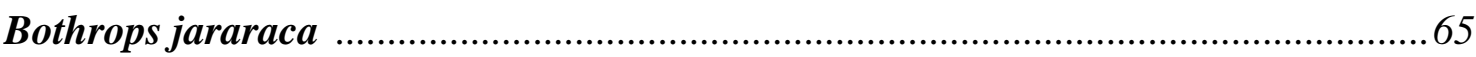

4.1.2 Isolamento de uma SVMP da classe P-I do veneno de Bothrops neuwiedi ....67

4.2 Caracterização das atividades hemorrágica e miotóxica .................................. 71

4.3 Ação da jararagina e BnP-1 em cultura de células endoteliais ……................. 73

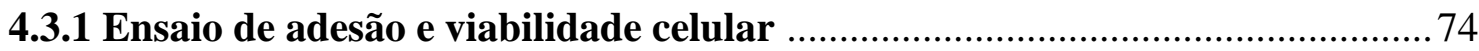

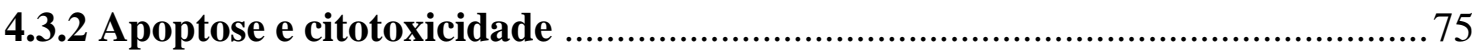

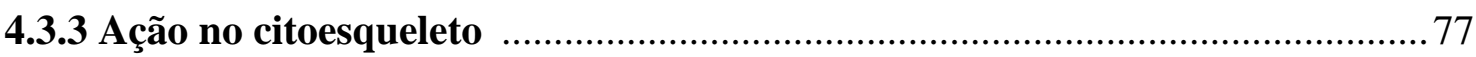

4.4 Ação das SVMPs em proteínas plasmáticas e de matriz extracelular .............. 80

4.4.1 Hidrólise dos componentes plasmáticos e de matriz extracelular ..................80 
4.4.2 Capacidade de ligação das SVMPs à proteínas plasmáticas e de

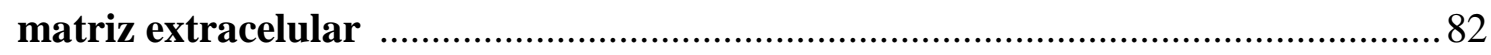

4.4.3 Região estrutural envolvida na ligação da jararagina ao colágeno …............ 84

4.4.4 Atividades biológicas da jararagina complexada com o colágeno ..................85

4.5 Ação da BnP1 e jararagina na pele do dorso de camundongos ….................... 87

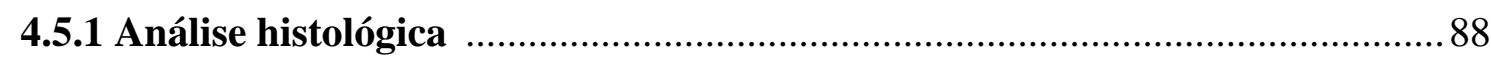

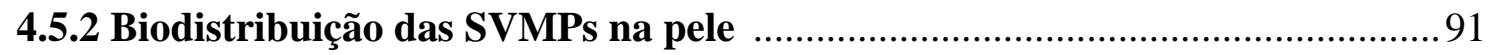

4.5.3 Degradação dos componentes de matriz extracelular .................................97

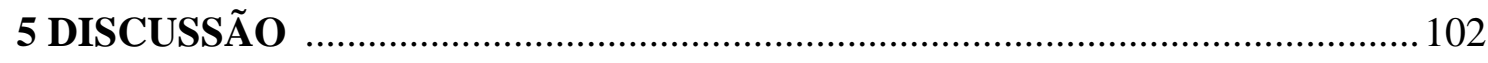

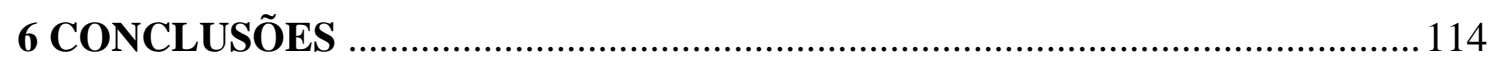

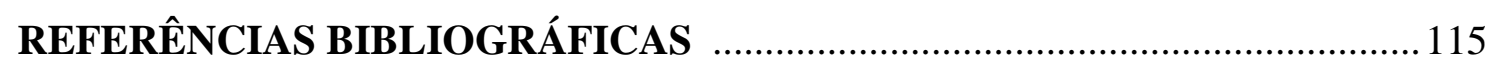




\section{INTRODUÇÃO}

Os acidentes ofídicos constituem um importante problema de saúde pública, principalmente nas regiões tropicais e subtropicais do mundo. No Brasil, as serpentes do gênero Bothrops são encontradas em todo território nacional, e são responsáveis por aproximadamente $90 \%$ dos acidentes ofídicos que ocorrem no país. Algumas espécies apresentam maior importância epidemiológica devido sua extensa distribuição geográfica como, por exemplo, Bothrops atrox na Amazônia, B. erythromelas no Nordeste, B. jararaca nas regiões Sul, Sudeste e Centro-Oeste e B. neuwiedi nas regiões Sudeste e Centro-Oeste. Baseado em dados do Ministério da Saúde são relatados, anualmente, cerca de 18.000 acidentes ocasionados por serpentes do gênero Bothrops (FRANÇA; MÁLAQUE, 2003). Apesar do baixo índice de letalidade, esses acidentes têm grande importância médica uma vez que podem resultar em seqüelas permanentes como perda da função ou amputação do membro afetado (GUTIERREZ et al., 2007).

Os venenos são constituídos por moléculas selecionadas durante o processo evolutivo das serpentes que possuem alta afinidade a importantes componentes fisiológicos relacionados à neurotransmissão, hemostasia e integridade tecidual (MOURA-DA-SILVA; BUTERA; TANJONI, 2007). Dentre as diversas classes de toxinas encontradas nesses venenos podemos citar as metaloproteinases, serinoproteinases, fosfolipases $\mathrm{A}_{2}$, peptídeos potencializadores de bradicinina, miotoxinas, disintegrinas, L-amino oxidases e lectinas tipo C, entre outras de composição minoritária (BJARNASON; FOX, 1994; KAMIGUTI et al., 1996a; MATSUI; FUJIMURA; TITANI, 2000; LU et al., 2005). Em geral, muitas dessas moléculas possuem múltiplos alvos de ação e agem de maneira sinérgica, exacerbando assim sua toxicidade. Nos venenos botrópicos, os principais alvos de ação estão relacionados ao controle da hemostasia e a componentes teciduais no local da picada. As serinoproteinases, metaloproteinases e lectina tipo $\mathrm{C}$ atuam em fatores da cascata de coagulação sangüínea, incluindo fibrinogênio, pró-trombina, fator $\mathrm{V}$, fator $\mathrm{X}$ e trombina, resultando em alterações no sistema hemostático (WHITE, 2005; LU et al., 2005). As disintegrinas, fosfolipases $\mathrm{A}_{2}$, metaloproteinases e lectinas do tipo $\mathrm{C}$ podem agir sobre plaquetas, induzindo a inibição ou a ativação da agregação plaquetária (HUANG et al., 1987; KAMIGUTI; HAY; ZUZEL, 1996b; LU et al., 2005). Algumas toxinas, tais como as metaloproteinases e fosfolipases $A_{2}$ ainda 
podem atuar em células inflamatórias promovendo a liberação de citocinas e outros mediadores inflamatórios (MOURA-DA-SILVA et al., 1996a; CLISSA et al., 2001; TEIXEIRA et al., 2003). Além disso, as metaloproteinases também agem sobre as células endoteliais promovendo a liberação de mediadores endógenos e a ruptura da adesão da célula à matriz extracelular, induzindo apoptose (GUTIERREZ et al., 2005; MOURA-DA-SILVA; BUTERA;TANJONI, 2007).

O resultado desses múltiplos efeitos pode ser visualizado, nas vítimas do envenenamento por serpentes do gênero Bothrops, em um quadro clínico caracterizado por efeitos locais e sistêmicos. Os efeitos locais freqüentemente incluem dor, edema, mionecrose e inflamação. Efeitos sistêmicos resultam em alterações na coagulação sangüínea, alterações cardiovasculares, choque hipovolêmico e alterações renais (WARREL, 1995; WARREL, 1996). A hemorragia, um dos efeitos mais graves do envenenamento botrópico, ocorre principalmente no local da picada e contribui para o efeito isquêmico e regeneração tecidual incompleta, mas também pode ocorrer de maneira sistêmica afetando diversos órgãos resultando em sérias complicações tais como choque cardiovascular, hemorragia pulmonar e hemorragia cerebral, que são sintomas associados à letalidade desses venenos (CARDOSO et al., 1993; WARREL, 1996, OTERO et al., 2002).

É importante ressaltar que a magnitude desses efeitos depende do tempo decorrido entre o acidente e a administração da soroterapia, da quantidade de veneno injetado e do local afetado (RIBEIRO; JORGE, 1997). Além disso, a composição do veneno pode apresentar heterogeneidade inter e intraespecífica relacionadas à idade, dieta e distribuição geográfica das serpentes, podendo resultar em diferentes sintomas clínicos (CHIPPAUX; WILLIAMS; WHITE, 1991).

As metaloproteinases são muito abundantes nos venenos botrópicos e desempenham papel importante no desencadeamento da maioria dos efeitos locais e sistêmicos observados após o envenenamento, tais como incoagulabilidade sangüínea, hemorragia, edema, hipotensão, inflamação e mionecrose (GUTIERREZ; RUCAVADO, 2002). Por isso, essas toxinas se tornaram importantes alvos de pesquisas nos últimos anos.

\subsection{Metaloproteinases de veneno de serpentes}

As metaloproteinases de veneno de serpentes (SVMPs-Snake Venom Metalloproteinases) compreendem uma série de enzimas com diferentes massas moleculares, 
encontradas em grande quantidade nos venenos das serpentes da família Viperidae, e também em algumas espécies das famílias Elapidae and Colubridae (JUNQUEIRA-DE-AZEVEDO; HO, 2002; GUO et al, 2007; CHING et al., 2006).

As SVMPs, juntamente com as ADAMs (A Disintegrin And Metalloproteinase) e as ADAMTs (A Disintegrin And Metalloproteinase with Thrombospondin motifs) compõem a subfamília M12B das metaloproteinases, também conhecidas como reprolisinas. Essas enzimas apresentam grande homologia no domínio metaloproteinase e em alguns casos, nos domínios localizados na porção carboxi-terminal subseqüente (FOX; SERRANO, 2008). As reprolisinas fazem parte de uma superfamília de metaloproteinases, conhecida como metzincinas, que também incluem as astacinas, MMPs (Matrix Metalloproteinases) e serralisinas. As metzincinas são caracterizadas por sua dependência catalítica por íons metálicos, especialmente o zinco e são amplamente expressas em eucariotos e procariotos (BODE; GOMIS-RUTH; STOCKER; 1993; HOOPER, 1994).

As SVMPs são sintetizadas como precursores latentes multimodulares que sofrem processamento proteolítico e resultam em moléculas cataliticamente ativas ou em domínios não catalíticos livres, conhecidos como disintegrinas. As análises dos cDNAs (Complementary Deoxyribonucleic Acid) e das seqüências protéicas das SVMPs demonstraram que este grupo de enzimas está relacionado com as MMPs e ADAMs, originando-se a partir de um gene ancestral comum. A divergência das MMPs originou o precursor das SVMPs e ADAMs. Esse evento foi acompanhado pela conservação das estruturas relacionadas à catálise, como o pró-domínio e o domínio metaloproteinase presentes nas MMPs, e também pela adição de novos domínios (disintegrina, tipodisintegrina, rico em cisteínas) na mesma posição do domínio hemopexina presente nas MMPs (MOURA-DA-SILVA; THEAKSTON; CRAMPTON, 1996b). Dessa forma, as SVMPs reúnem propriedades catalíticas das MMPs e propriedades adesivas das ADAMs, constituindo-se uma versátil classe de toxinas capaz de interferir no equilíbrio celular de diferentes maneiras.

As SVMPs possuem massa molecular variando entre 20 a $110 \mathrm{kDa}$ e são divididas em classes e subclasses de acordo com a distribuição de seus domínios estruturais. Essas enzimas são sintetizadas em diferentes combinações dos seguintes domínios: peptídeo sinal, pródomínio, metaloproteinase, disintegrina ou tipo-disintegrina, rico em cisteínas e tipo lectina. A presença desses domínios varia de acordo com a classe ou com o processamento proteolítico necessário para a maturação dessas enzimas (FOX; SERRANO, 2008). 
O peptídeo sinal ou pré-domínio é composto por aproximadamente 18 aminoácidos e é responsável pelo direcionamento da proteína nascente para o interior do retículo endoplasmático para processamento e secreção. O pró-domínio, constituído em média por 200 aminoácidos, está aparentemente envolvido na inativação da enzima no interior da glândula de veneno. Essa estrutura apresenta uma seqüência conservada, PKMCGV, também presente no pró-domínio das MMPs, que está relacionado com o mecanismo cystein-switch, responsável pelo controle do estado de ativação das MMPs através do bloqueio do sítio catalítico (estado inativado) e processamento proteolítico do pró-domínio (estado ativo) (BODE; GOMIS-RUTH; STOCKER; 1993; STOCKER; BODE, 1995).

O domínio metaloproteinase das SVMPs conserva as principais estruturas funcionais das MMPs: a sequência relacionada ao sítio de ligação do átomo de zinco HEXXHXXGXXH, e um resíduo de metionina na porção carboxi terminal na volta abaixo do sítio ligante de zinco (met-turn), que estabiliza os três resíduos de histidina envolvidos na catálise (BODE; GOMIS-RUTH; STOCKER; 1993; STOCKER; BODE, 1995). A representação esquemática do sítio catalítico das SVMPs e de outros membros da família das metzincinas está mostrada na Figura 1. Apesar de muitas proteínas da família das ADAMs possuírem atividade enzimática, em alguns membros a região que codifica a seqüência de ligação com o zinco apresenta mutações com a substituição de histidinas essenciais, resultando em moléculas enzimaticamente inativas (MOURA-DA-SILVA; THEAKSTON; CRAMPTON, 1996b).

O domínio disintegrina pode ser encontrado na forma livre nos venenos viperídeos, e são conhecidos como as disintegrinas clássicas. Estas moléculas são capazes de interagir com integrinas plaquetárias com alta afinidade através da seqüência RGD (HUANG et al., 1987). No entanto, substituições no tripeptídeo RGD tais como MLD e KTS também foram descritas (CALVETE et al., 2005). O domínio rico em cisteínas, assim como o domínio disintegrina possui alta densidade de resíduos de cisteínas e está relacionado com propriedades adesivas a componentes plasmáticos e de matriz extracelular (SERRANO et al., 2006). 


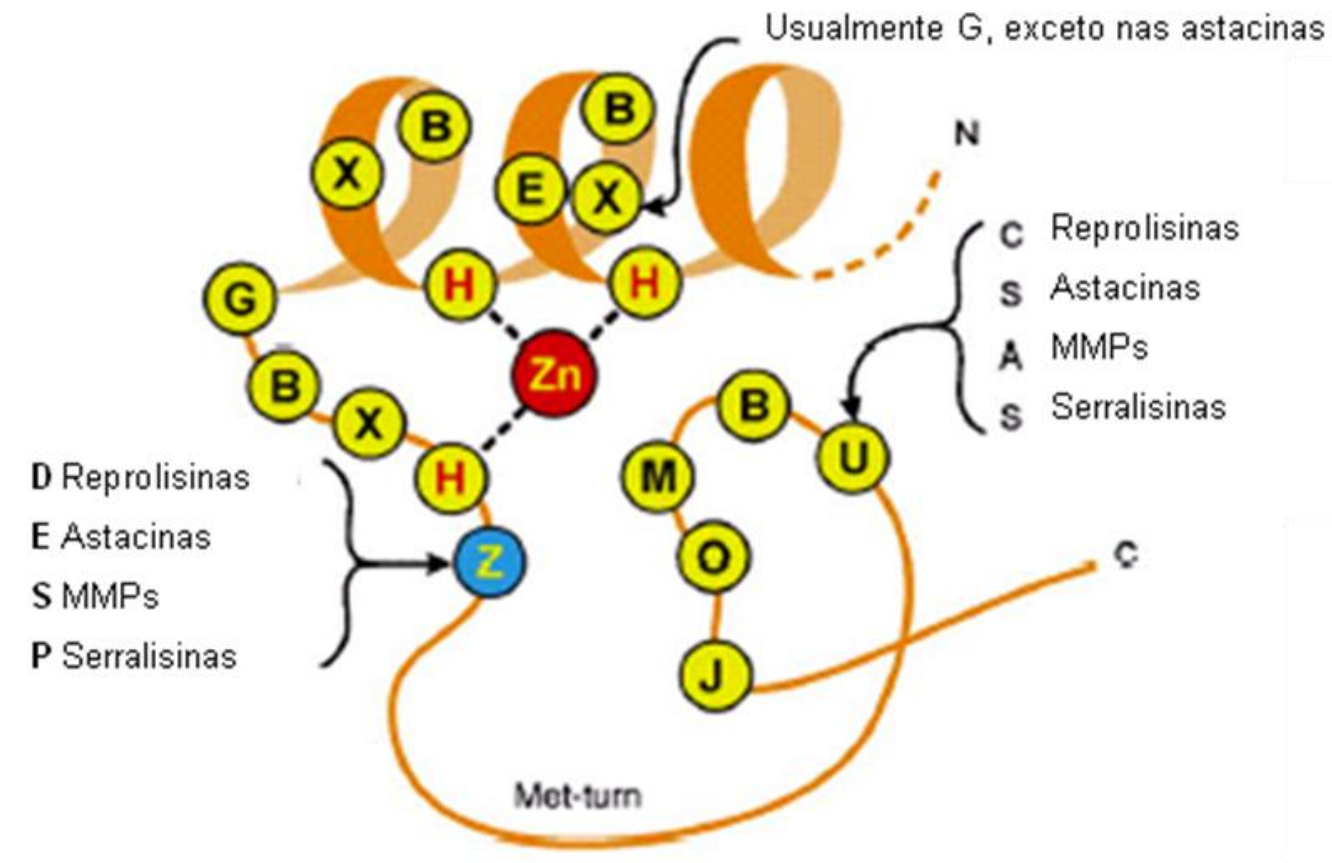

Figura 1- Representação esquemática da estrutura do sítio ativo das metaloproteinases da família das metzincinas (Adaptada de FOWLKES; WINKLER, 2002).

Recentemente, Fox e Serrano (2008), propuseram uma classificação onde 11 classes e subclasses de SVMPs foram identificadas: P-Ia, P-IIa, P-IIb, P-IIc, P-IId, P-IIe, D-I, P-IIIa, PIIIb, P-IIIc e P-IIId (Figura 2). O critério utilizado para classificar as SVMPs foi essencialmente baseado na presença ou ausência dos domínios não catalíticos que são observados via transcriptoma ou proteínas isoladas do veneno. 


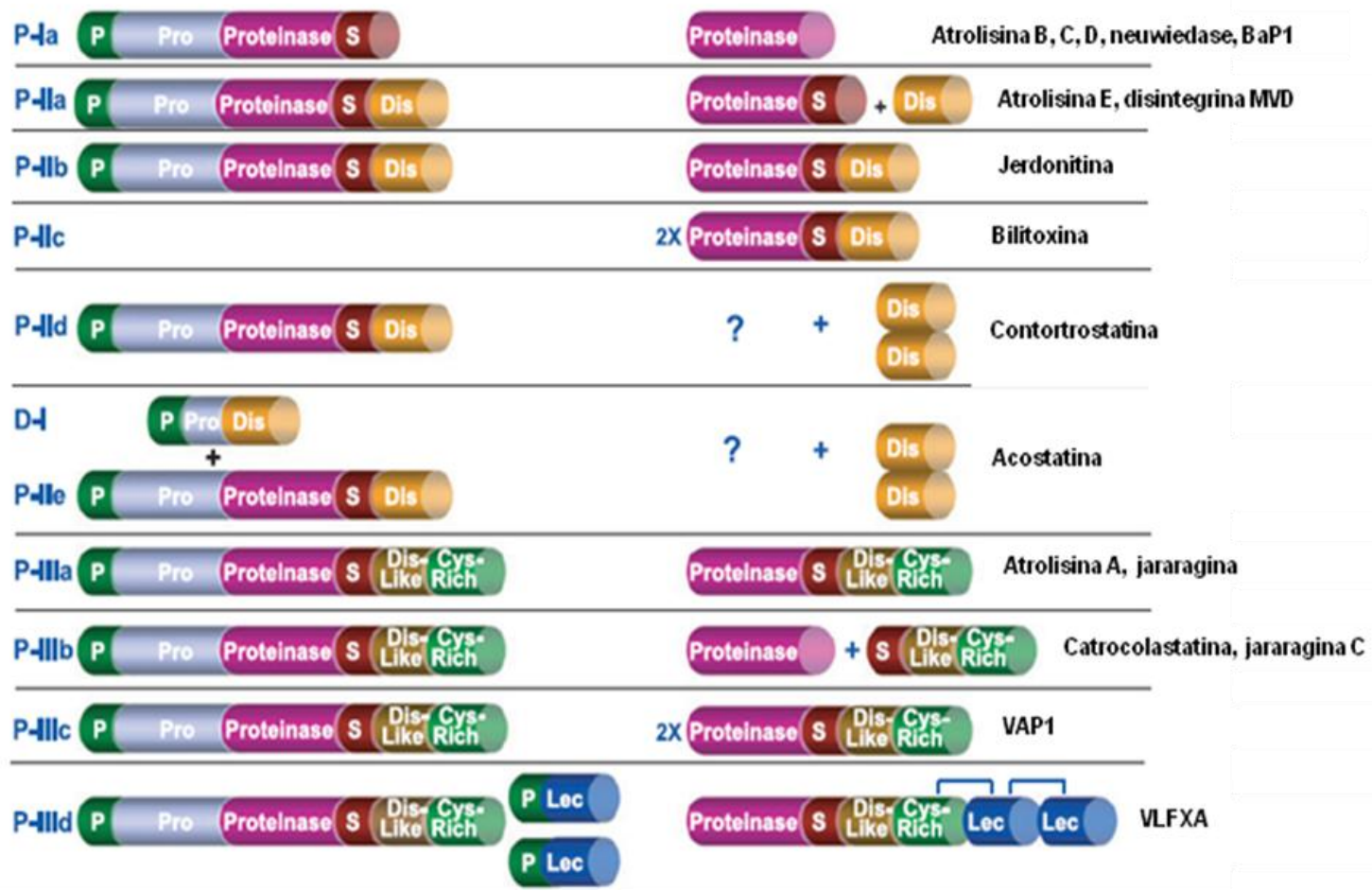

Figura 2- Classificação das SVMPs. As SVMPs são sintetizadas na forma latente como precursores multimodulares que sofrem diferentes estágios de processamento. P: prédomínio, Pro: pró-domínio, Proteinase: domínio metaloproteinase. S: sequiência de aminoácidos entre o domínio catalítico e disintegrina ou tipo-disintegrina, Dis: disintegrina, Dis-Like: domínio tipo-disintegrina, Cys-Rich: domínio rico em cisteínas, Lec: domínio ligante de lectina (Adaptado de FOX; SERRANO, 2008).

$\mathrm{Na}$ classe P-Ia encontram-se as metaloproteinases de massa molecular entre 20 a 30 $\mathrm{kDa}$, com ação hemorrágica baixa ou ausente. A classe P-Ia origina-se de precursores contendo os domínios pré, pró e catalítico. Em sua forma madura possui apenas o domínio catalítico, que é composto de aproximadamente 200 resíduos de aminoácidos no qual está a seqüência ligante de zinco. Em geral, as SVMPs da classe P-Ia são enzimas fibrinogenolíticas e podem apresentar atividades mionecrótica e pró-inflamatória (GUTIERREZ; RUCAVADO, 2000).

A classe P-II origina-se de precursores contendo os domínios pré, pró, catalítico e disintegrina. A classe PIIa inclui metaloproteinases de baixa massa molecular semelhantes às toxinas da classe P-I e também as disintegrinas. As disintegrinas possuem de 50 a 60 resíduos de aminoácidos incluindo em sua maioria uma seqüência RGD que compete com o 
fibrinogênio plasmático pela integrina $\alpha_{\mathrm{IIb}} \beta_{3}$ presente na superfície de plaquetas, inibindo assim a agregação plaquetária (CALVETE et al., 2005). Alternativamente, as toxinas da classe P-II podem ser encontradas com o domínio catalítico e disintegrina não processados (PIIb), na forma de disintegrinas diméricas com a presença do domínio catalítico (P-IIc), disintegrinas homodiméricas (P-IId) ou heterodímericas (P-IIe).

A classe P-III é representada por toxinas altamente hemorrágicas, com massa molecular entre 60 a $110 \mathrm{kDa}$. A classe P-III origina-se de precursores contendo os domínios pré, pró, catalítico, tipo-disintegrina e rico em cisteínas. O domínio tipo-disintegrina é semelhante aos peptídeos disintegrinas encontrados nas SVMPs do tipo PII. No entanto, esse domínio exibe substituições funcionais na seqüência RGD, tais como ECD e DCD, e é expresso sempre em adição com um domínio carboxi terminal rico em resíduos de cisteínas que também promove a inibição da agregação plaquetária (KAMIGUTI et al., 1997; KAMIGUTI et al., 2003). De acordo com diferenças no processamento proteolítico, as toxinas da classe P-III também podem ser encontradas nos venenos em formas alternativas. Em sua maioria, são expressas com os domínios metaloproteinases, tipo disintegrina e rico em cisteínas (P-IIa). Entretanto, algumas toxinas sofrem processamento proteolítico no domínio catalítico, resultando em uma molécula composta pelos domínios tipo disintegrina e rico em cisteínas (P-IIIb). Além disso, podem ser encontradas na forma dimérica, constituindo a subclasse P-IIIc. A subclasse P-IIId, classe P-IV de acordo com a antiga classificação (BJARNASON; FOX, 1994), é caracterizada pela adição de dois domínios tipo lectina na porção carboxi-terminal da molécula.

A diversidade estrutural das SVMPs confere às mesmas a capacidade de interferir em diversos sistemas celulares, afetando a hemostasia de diferentes maneiras. De modo geral, o mecanismo de ação das SVMPs está relacionado à proteólise de componentes da matriz extracelular (GUTIERREZ et al., 2005), proteínas plasmáticas (KAMIGUTI et al., 1994a; SILVA et al., 2003; WANG; SHIH; HUANG, 2004), proteínas de membrana celular (KAMIGUTI; HAY; ZUZEL 1996b; WU; HUANG, 2003) e à interação com receptores específicos, como integrinas de superfície de plaquetas (DE LUCA et al., 1995; YOU et al., 2006), células endoteliais (SOUZA et al., 2000; COMINNETTI et al., 2004; SELISTRE-DEARAUJO et al., 2005; SCHATTNER et al., 2005) e fibroblastos (ZIGRINO et al., 2002), ativando ou inibindo a resposta celular. Estes efeitos podem resultar em várias alterações fisiopatológicas tais como inflamação, inibição da agregação plaquetária, apoptose e hemorragia (GUTIERREZ et al., 2005). 


\subsection{Efeitos das SVMPs em componentes celulares}

\subsubsection{Células inflamatórias}

As SVMPs desempenham papel importante na resposta inflamatória induzida por serpentes botrópicas (MOURA-DA-SILVA et al., 1996a; CLISSA et al., 2001; COSTA et al., 2002; RUCAVADO et al., 2002; LAING et al., 2003; GALLAGHER et al., 2005; FERNANDES et al., 2006; DE MORAES; SELISTRE-DE-ARAÚJO, 2006; LOPES et al., 2009). A primeira evidência de que componentes de venenos ativam mediadores inflamatórios endógenos foi demonstrado por nosso grupo. Moura-da-Silva et al. (1996a) verificaram que a jararagina, SVMP da classe P-III isolada de B. jararaca, é capaz de processar a forma precursora do TNF- $\alpha$ (Tumor Necrosis Factor- $\alpha$ ), na mesma posição que a TACE (TNF $\alpha$ converting enzyme /ADAM17), liberando o TNF- $\alpha$ em sua forma biologicamente ativa. Estudos posteriores indicaram que a jararagina também induz a expressão de TNF- $\alpha$, IL6 (Interleucina-6) e IL-1 $\beta$ (Interleucina -1 $\beta$ ) em cultura de macrófagos (CLISSA et al., 2001), e que a necrose induzida por esta toxina foi completamente inibida em camundongos knock-out deficientes em TNFR1 (Tumor Necrosis Factor- $\alpha$ Receptor 1) e TNFR2 (Tumor Necrosis Factor- $\alpha$ Receptor 2), e parcialmente inibida em animais deficientes em IL-6 (LAING et al., 2003). Em outro estudo, Gallagher et al. (2005) investigaram o efeito da jararagina no perfil da expressão gênica de fibroblastos humanos in vitro e em tecido murino in vivo e verificaram um significativo aumento na expressão gênica de IL-1 $\beta$, IL-6, TNF- $\alpha$, CXCL1 (Chemokine-C-X-C-motif-ligand 1), CXCL2 (Chemokine-C-X-C-motif-ligand 2) e CXCL8 (Chemokine-C-X-C-motif-ligand 8). Conseqüentemente, a jararagina induz migração leucocitária em camundongos, de forma dependente de macrófagos (COSTA et al., 2002), e induz hiperalgesia e edema (DALE et al., 2004). A HF3 (Hemorrhagic Factor 3), outra SVMP da classe P-III isolada de B. jararaca, também é capaz de promover a ativação de macrófagos acentuando a fagocitose de partículas opsonizadas por essas células (SILVA et al., 2004).

As toxinas da classe P-I também possuem ação pró-inflamatória. A BaP1, SVMP da classe P-I isolada do veneno de $B$. asper, induz a migração de leucócitos e aumenta os níveis locais de IL-1 $\beta$, IL-6 e de algumas MMPs, tais como a MMP-9 (RUCAVADO et al., 2002). 
Além disso, aumento dos níveis de IL-1 $\beta$ também foi detectado no exsudato peritoneal de camundongos injetados com essa toxina (FERNANDES et al., 2006). A neuwiedase, SVMP da classe P-I isolada do veneno $B$. neuwiedi, também possui ação pró-inflamatória caracterizada pela indução de edema e infiltrado leucocitário (RODRIGUES et al., 2001). A reação inflamatória induzida pela neuwiedase foi melhor estudada num recente trabalho (LOPES et al., 2009), onde os autores verificaram a presença de evidente infiltrado inflamatório e aumento de MMP-9 (matrix metalloproteinase 9), IL-8 (Interleucina-8), IL-1 $\beta$ e IL-6, nas primeiras horas após a injeção da toxina no músculo gastrocnêmio. Usando cultura de macrófagos peritoneais, foram observadas a liberação de IL-1 $\beta$ e IL-6. Em cultura de células musculares, foi observado um aumento significante da quimiocina IL-8, sugerindo a participação dessas células na liberação de quimiocinas que intensificam o acúmulo de células inflamatórias no local da injúria.

O papel dos domínios estruturais das SVMPs na atividade pró-inflamatória ainda não está totalmente esclarecido. Algumas ações do domínio catalítico, tais como a proteólise de componentes da matriz extracelular (BARRAMOVA et al.,1989), ativação de MMPs (RUCAVADO; NÚNEZ; GUTIÉRREZ, 1998; RUCAVADO et al., 2002; LOPES et al., 2009), processamento do pró-TNF (MOURA-DA-SILVA et al., 1996a) e de integrinas de superfície celular (KAMIGUTI; HAY; ZUZEL, 1996), podem contribuir para a resposta inflamatória induzida pelas SVMPs. No entanto, a inativação da atividade catalítica da jararagina, por exemplo, não é suficiente para inibir completamente o recrutamento de leucócitos (COSTA et al., 2002) e a síntese de citocinas pró-inflamatórias (CLISSA et al., 2001), sugerindo uma ação direta da toxina nos receptores celulares. O papel dos domínios não catalíticos na atividade pró-inflamatória induzida pela jararagina foi investigado num trabalho realizado por Clissa et al. (2006). Utilizando a jararagina-C, que possui somente os domínios tipo-disintegrina e rico em cisteínas da jararagina, esses autores verificaram que esta toxina induziu a liberação de citocinas pró-inflamatórias tais como o TNF- $\alpha$, IL-1 $\beta$ e IL-6 e aumentou o rolamento de leucócitos nas paredes de vênulas pós-capilares. Além disso, os domínios recombinantes tipo disintegrina e rico em cisteínas da HF3 também foram capazes de promover a ativação de macrófagos via integrina $\alpha_{M} \beta_{2}$ (SILVA et al., 2004). Esses dados indicam que os domínios não catalíticos também participam da ação pró-inflamatória induzida pela SVMPs. 


\subsubsection{Plaquetas}

As plaquetas são importantes alvos das SVMPs, cuja ação pode promover a ativação ou inibição da agregação plaquetária através de diferentes mecanismos (KAMIGUTI, 2005). Algumas SVMPs inibem a agregação plaquetária pelo bloqueio de receptores da superfície de plaquetas tais como $\alpha_{2} \beta_{1}, \alpha_{\mathrm{IIb}} \beta_{3}$ (DE LUCA et al., 1995; SOUZA et al., 2000; YOU et al., 2006). Outras SVMPs inibem a agregação plaquetária pela ligação ao colágeno (ZHOU; DANGELMAIER; SMITH, 1996; LIU; HUANG, 1997) ou pela ação proteolítica sobre integrinas plaquetárias e no VWF (Von Willenbrand Factor) (KAMIGUTI; HAY; ZUZEL, 1996b; WANG; SHIH; HUANG, 2004). A inibição da agregação plaquetária via ADP (Adenosina Difosfato) por SVMPs também foi descrita (COMINETTI et al., 2003; CHEN et al., 2003). Além disso, as SVMPs também podem induzir a agregação plaquetária (WIJEYEWICKREMA; BERNDT; ANDREWS, 2005).

Os principais membros das SVMPs que atuam em plaquetas são as disintegrinas clássicas. A inibição da agregação plaquetária induzida pelas disintegrinas é atribuída a presença do tripeptídeo RGD (ADLER et al., 1991; SAUDEK; ATKINSON; PELTON, 1991) capaz de se ligar a integrina $\alpha_{\mathrm{IIb}} \beta_{3}$ presente na superfície de plaquetas, bloqueando a ligação do fibrinogênio a este receptor (HUANG et al., 1987; NIEWIAROWSKI et al., 1994). Uma vez que esse é o passo final da agregação plaquetária, as disintegrinas são capazes de inibir a agregação plaquetária induzida por diferentes agonistas.

Além das disintegrinas, as SVMPs da classe P-I e P-III também podem interferir na agregação plaquetária. No entanto, como elas não possuem o tripeptídeo RGD, essas proteínas não bloqueiam a interação entre a integrina $\alpha_{\mathrm{IIb}} \beta_{3}$ e o fibrinogênio, mas atuam via colágeno ou VWF. O efeito das SVMPs sobre a ativação de plaquetas via VWF pode ser atribuída tanto ao efeito da toxina no VWF quanto a ação em seu receptor GP Ib-IX-V (Glicoproteína Ib-IX-V). A hidrólise do VWF resulta na inibição da agregação plaquetária, como descrito para algumas toxinas da classe P-I, como a proteinase-I (MASCELLI; KIRBY, 1988) e a crotalina (WU; PENG; HUANG, 2001) assim como para toxinas da classe P-III, como a kaouthiagin (HAMAKO et al., 1998), acurrhagin (WANG; HUANG, 2002) e a jararagina (KAMIGUTI et al., 1996a). Os efeitos das SVMPs sobre o receptor do VWF envolve, na maioria das vezes, a clivagem da GPIb (glicoproteína Ib), como descrito para a mocarhagin 
(WARD et al., 1996) e para SVMPs da classe P-I como a crotalina (WU; PENG; HUANG, 2001) e a kistomin (HUANG; CHANG; TENG, 1993), resultando na inibição da agregação plaquetária.

A ação das SVMPs na agregação plaquetária induzida pelo colágeno é descrita para as toxinas da classe P-III, que contêm os domínios tipo disintegrina e rico em cisteínas. Essas toxinas são capazes de bloquear a ligação do colágeno a integrina $\alpha_{2} \beta_{1}$, inibindo a agregação plaquetária. A jararagina inibe a agregação plaquetária induzida pelo colágeno através do bloqueio do receptor $\alpha_{2} \beta_{1}$ (DE LUCA et al., 1995) ou pela clivagem proteolítica da subunidade $\beta_{1}$ deste mesmo receptor (KAMIGUTI; HAY; ZUZEL, 1996b). Algumas SVMPs da classe P-III também podem interferir no mecanismo de agregação plaquetária através da ligação ao colágeno. Como demonstrado anteriormente, a crovidisina (LIU; HUANG, 1997) e a catrocollastatina (ZHOU; DANGELMAIER; SMITH, 1996) são capazes de se ligar a fibras de colágeno bloqueando sua interação com as plaquetas, inibindo assim a função plaquetária.

Os efeitos das SVMPs da classe P-III na inibição da agregação plaquetária induzida pelo colágeno está aparentemente relacionada à ação dos domínios tipo disintegrina e rico em cisteínas (ZHOU; DANGELMAIER; SMITH, 1996; JIA et al., 1997; MOURA-DA-SILVA et al., 1999; ASSAKURA et al., 2003; KAMIGUTI et al., 2003). No entanto, alguns trabalhos relatam que o domínio catalítico também pode estar envolvido com a inibição da agregação plaquetária. Ivaska et al. (1999) mostraram que o peptídeo cíclico RKKH, derivado do domínio catalítico da jararagina, também inibiu a agregação plaquetária induzida pelo colágeno. Estudos realizados com a halysase, uma SVMP-III isolada do veneno de Gloydius halys (YOU et al., 2006), mostrou que a inibição da agregação plaquetária via colágeno pode ser resultante de uma cooperação entre o domínio tipo disintegrina e metaloproteinase, uma vez que o tratamento da toxina com EDTA reduziu significativamente a inibição da agregação plaquetária. Portanto, a inibição da agregação plaquetária induzida pela SVMPs da classe PIII pode ser resultado da interação de diferentes domínios. 


\subsubsection{Células endoteliais}

A adesão célula-matriz é essencial para os processos de migração, organização tecidual e diferenciação e desempenha papel central durante a embriogênese, remodelamento e homeostasia dos tecidos. Além disso, a matriz extracelular regula processos biológicos tais como sobrevivência e proliferação celular, cicatrização e tumorogênese (ZAMIR; GEIGER, 2001). A transdução de sinal entre a matriz extracelular e as células é dependente da sinalização mediada por integrinas e a interação entre a matriz, integrinas e o citoesqueleto celular ocorre através de sítios denominados adesões focais (BERRIER; YAMADA, 2007). Portanto, a interferência na adesão focal ou em componentes da matriz extracelular, efeitos relacionados à ação das SVMPs, podem resultar numa variedade de respostas celulares influenciando o destino celular.

As SVMPs da classe P-III, assim como as disintegrinas clássicas, podem agir como ligantes solúveis. A jararagina, por exemplo, é capaz de inibir de maneira específica, a ligação da integrina $\alpha_{2} \beta_{1}$ ao colágeno (DE LUCA et al.,1995; MOURA-DA-SILVA, et al., 2001). Além disso, SVMPs da classe P-I e P-III hidrolisam componentes de matriz extracelular (GUTIERREZ et al., 2005) e integrinas envolvidas na adesão e ativação celular (KAMIGUTI et al., 1994). Portanto, a ação das SVMPs em células endoteliais envolve propriedades proteolíticas e anti-adesivas, que conjuntamente resulta na perda da interação célula-matriz, induzindo a morte celular via apoptose.

A literatura descreve um grande número de SVMPs da classe P-I e P-III capazes de induzir apoptose em células endoteliais. A apoptose induzida pela HVI, uma metaloproteinase homodimérica da classe P-III isolada de Trimeresurus flavoviridis (MASUDA et al., 2001), é dependente da ação proteolítica. A VLAIP, uma P-III isolada do veneno de Vipera libetina, induz apoptose através da inibição da adesão das células endoteliais a proteínas da matriz extracelular (TRUMMAL et al., 2005). A apoptose induzida pela halyase, outra P-III isolada de Cloydius halys (YOU et al., 2003) e pela BaP1, uma P-I isolada do veneno de B. asper é decorrente da perda de adesão da célula à matriz, processo conhecido como anoikis (DÍAZ et al., 2005). Por outro lado, estudos realizados com a graminelisina, outra P-I isolada do veneno de Trimeresurus gramineus, relataram que a apoptose foi decorrente da degradação dos componentes da matriz e clivagem das junções aderentes, induzindo apoptose através de um efeito direto (WU; HUANG, 2003). 
Entretanto, as SVMPs também podem ativar as células endoteliais. A jararagina e berythractivase, SVMP da classe P-III isolada de B. erythromelas, ativam a produção de óxido nítrico, prostaciclina e IL-8 em células endoteliais humanas (SCHATTNER et al., 2005). Em paralelo, a alternagina-C, composta pelos domínios tipo disintegina e rico em cisteínas bastante similares aos da jararagina (SOUZA et al., 2000), induz a proliferação das células endoteliais in vitro (COMINNETTI et al., 2004) e aumento da expressão de VEGF (Vascular Endothelial Growth Factor) por um mecanismo aparentemente dependente de ligação à integrina $\alpha 2 \beta 1$ (SELISTRE-DE-ARAUJO et al., 2005). Em cultura de fibroblastos, a jararagina pode ativar a resposta celular, mimetizando um ligante endógeno. Zigrino et al. (2002) mostraram que a ligação da jararagina à integrina $\alpha_{2} \beta_{1}$ da superfície de fibroblastos mimetiza a sinalização induzida pelo colágeno, estimulando a produção de MMPs.

Em resumo, a ação das SVMPs em células endoteliais pode ser atribuída à ruptura da adesão focal por mecanismos dependentes ou não do domínio catalítico, clivagem de junções aderentes, ativação das células endoteliais e processamento de componentes endógenos. Em conjunto, esses efeitos podem resultar em drásticas alterações na hemostasia induzindo o estabelecimento de lesões hemorrágicas, características dos envenenamentos botrópicos.

\subsection{Ação hemorrágica das SVMPs}

A ação hemorrágica induzida pelas SVMPs é uma das mais graves consequiências do envenenamento botrópico. Um evidente quadro hemorrágico está relacionado com a ação destas toxinas sobre capilares sangüíneos resultando em hemorragia interna. Em acidentes leves, a ação hemorrágica é limitada ao sítio da picada. Contudo, em casos severos a hemorragia se espalha, afetando tecidos circunvizinhos ou até órgãos distantes tais como coração, pulmões, rins, intestino e cérebro (HATI et al., 1999). Uma conseqüência indireta da hemorragia é a necrose das fibras musculares, provocada pela interrupção do fluxo sangüíneo para o local danificado (GUTIERREZ; RUCAVADO, 2000). O quadro hemorrágico é comumente agravado por alterações no sistema hemostático como, por exemplo, a inibição da agregação plaquetária (DE LUCA et al., 1995; KAMIGUTI; HAY; 
ZUZEL, 1996b) e o consumo dos fatores da coagulação sangüínea, tais como o fibrinogênio (WILLIS e TU, 1988).

Apesar do mecanismo de ação das toxinas hemorrágicas ainda não estar totalmente esclarecido, são postulados dois modelos para o desencadeamento deste efeito. O primeiro, descrito para a maioria das toxinas hemorrágicas, é denominado hemorragia per rhexis. Neste modelo, as células endoteliais são rapidamente afetadas devido à ação proteolítica sobre componentes da membrana basal vascular, tais como o colágeno tipo IV, fibronectina e laminina. Conseqüentemente, a integridade celular é comprometida ocorrendo o desenvolvimento de espaços através dos quais os componentes do sangue extravasam e atingem o espaço intersticial. Nenhuma alteração nas junções intercelulares foi observada (MCKY et al., 1970; OWNBY; BJARNASON; TU, 1978). Um segundo mecanismo denominado hemorragia per diapedesis também já foi descrito para algumas toxinas hemorrágicas. Neste modelo o extravasamento de sangue ocorre exclusivamente através das junções endoteliais e a viabilidade celular não é afetada (OSAKA et al., 1971; OSAKA, JUST, HABERMANN, 1973). No entanto, esta aparente discrepância quanto ao mecanismo de ação hemorrágica pode ser devido simplesmente a diferenças entre o tempo, dose e via de administração da toxina e das metodologias empregadas (HATI et al., 1999).

\subsubsection{Modelo ex vivo para estudo da hemorragia induzida pelas SVMPs}

Estudos in vitro mostrando a ação de SVMPs em componentes da matriz extracelular ou ainda em culturas de células endoteliais são de grande valia para entender o mecanismo de ação hemorrágica dessas toxinas. Entretanto, a análise isolada de componentes do endotélio não substitui os ensaios in vivo, onde a ação hemorrágica das SVMPs pode ser visualizada em decorrência da ação combinada dessas toxinas nos diferentes componentes do endotélio vascular.

Um aspecto intrigante, ainda não elucidado, é a grande diferença da atividade hemorrágica exibida por diferentes SVMPs. Sabe-se que todas são capazes de degradar componentes da membrana basal in vitro, passo determinante para a hemorragia. Entretanto, a maioria das SVMPs da classe P-I não induzem hemorragia ou são fracamente hemorrágicas. 
Por outro lado, a maioria das toxinas da classe P-III são altamente hemorrágicas, mas alguns membros dessa classe não são capazes de induzir hemorragia e agem com potentes fatores pró-coagulantes. Grande parte das diferenças funcionais observadas entre as SVMPs das classes P-I e P-III têm sido atribuídas à presença dos domínios não catalíticos, tipodisintegrina e rico em cisteínas. De um modo geral, o domínio catalítico é relacionado à proteólise de componentes plasmáticos e da matriz extracelular e os domínios não catalíticos associados à interação com receptores de plaquetas e células endoteliais. No entanto, uma única atividade biológica pode ser resultante da ação sinérgica de vários domínios estruturais. Um bom exemplo é a atividade hemorrágica induzida por metaloproteinases da classe PIII, correlacionada com a ação do domínio catalítico sobre componentes da MB vascular. Contudo, a maioria das SVMPs da classe P-I também degrada componentes da MB, mas não induzem hemorragia, sugerindo que propriedades adesivas dos domínios não catalíticos, presentes nas toxinas da classe PIII, são fundamentais para a expressão desta atividade. Diante do exposto, estudos comparativos entre toxinas da classe P-I e P-III são necessários para esclarecer a diferença funcional dessas toxinas, estabelecendo os requisitos estruturais necessários para a expressão da atividade hemorrágica.

Neste trabalho, optamos por realizar um estudo comparativo entre SVMPs da classe PI e P-III com o objetivo de investigar a diferença de potencial hemorrágico entre as SVMPs. Para tanto, a jararagina, protótipo de SVMP da classe P-III isolada do veneno de Bothrops jararaca (PAINE et al., 1992), foi escolhida como modelo de SVMP da classe P-III. Como modelo de SVMP da classe P-I, escolhemos a neuwiedase, isolada do veneno de Bothrops neuwiedi (RODRIGUES et al., 2000). A avaliação experimental do potencial hemorrágico das SVMPs é comumente realizada após a injeção intradérmica na pele do dorso de camundongos. A pele é um órgão muito vascularizado e rico em matriz extracelular e, portanto constitui-se num bom modelo para o estudo do mecanismo de indução da hemorragia. A Figura 3 mostra a representação esquemática da pele e de seus anexos. 


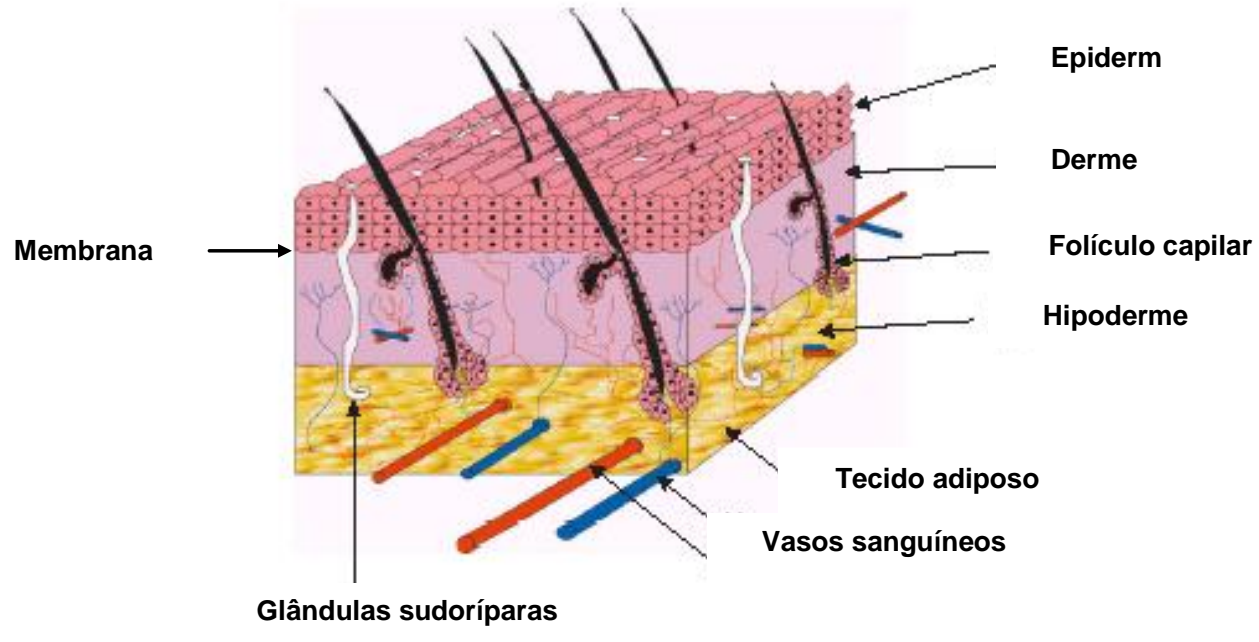

Figura 3- Representação esquemática da pele e de seus anexos. A pele de um mamífero adulto é dividida em epiderme e derme. A epiderme, camada mais superficial, é um epitélio pavimentoso estratificado, composto principalmente de queratinócitos, e contendo um pequeno número de células de Langerhans, melanócitos, células de Merkel e linfócitos migratórios. A derme, maior componente da pele, é composta por tecido conjuntivo, folículos capilares, glândulas sebáceas e sudoríparas e os vasos sangüíneos (Adaptado de METCALFE et al., 2007).

A derme, maior componente da pele, é composta por tecido conjuntivo, folículos capilares, glândulas sebáceas e sudoríparas e os vasos sangüíneos. O colágeno é o principal componente da derme e cerca de $80 \%$ do colágeno dérmico compõe se de fibras do tipo I, a maior parte do colágeno restante é formado por fibras do tipo III. Fibras elásticas, glicosaminoglicanos e proteoglicanos são encontradas no interstício de fibras de colágeno, proporcionando elasticidade e substratos importantes para a migração e fixação das células (BRESSLER; BRESSLER, 1989). A derme organiza-se em duas zonas: a derme papilar e a derme reticular. A região papilar é imediatamente adjacente à epiderme, e acompanha seu contorno, inclusive em torno dos órgãos anexos, como os folículos capilares e glândulas sudoríparas, sendo formada principalmente por colágeno tipo III. A derme reticular é mais espessa e seu principal componente é o colágeno tipo I. A hipoderme, ou camada subcutânea da pele é a porção mais profunda da derme, formada por tecido conjuntivo frouxo, composto por colágeno, fibras elásticas e uma grande quantidade de células adiposas (BRESSLER; BRESSLER, 1989). A derme contém diversos tipos celulares como os fibroblastos, macrófagos, miócitos e mastócitos. Os fibroblastos, entremeados entre feixes de colágenos, 
são os principais responsáveis pela síntese do colágeno, elastina e de outros componentes da matriz extracelular (HOHENESTER; ENGEL, 2002).

A matriz extracelular (MEC) é constituída por um complexo, em proporções variáveis, de diversas proteínas e polissacarídeos que se organizam formando uma rede, em parte responsável pela diversidade morfológica e funcional dos tecidos. De maneira geral, a MEC é formada por diferentes combinações de vários tipos de colágenos, fibras elásticas, fibronectina, laminina, proteoglicanos e glicosaminoglicanos, que se organizam formando substrato apropriado para a adesão dos diferentes tipos celulares (BERRIER; YAMADA, 2007).

As células estão em contato direto com a MEC através de receptores de superfície celular, dentre os quais as integrinas ocupam papel proeminente. As integrinas são receptores heterodiméricos que apresentam subunidades $\alpha$ e $\beta$ associadas não covalentemente. Atualmente, são descritas 18 subunidades $\alpha$ e 8 subunidades $\beta$, e a combinação entre elas resulta nos 24 diferentes tipos conhecidos de integrinas, capazes de se ligar a vários componentes da MEC com diferente afinidade (LUO; CARMAN; SPRINGER, 2007). Esta variedade de subunidades contribui para a diversidade no reconhecimento de ligantes, na ligação aos componentes da matriz e na ativação de diferentes vias de sinalização (HUMPHRIES; BYRON; HUMPHRIES, 2006).

A MEC pode organizar-se em estruturas especiais chamadas membranas basais (MB). As MB estão sempre presentes em tecidos epiteliais, separando-os do tecido conjuntivo adjacente, e em torno de vasos sangüíneos, células musculares, adipócitos, nervos periféricos e células de Schwann. Essas estruturas são responsáveis pela compartimentalização, organização e suporte estrutural dos tecidos, e influenciam na sobrevivência, proliferação, diferenciação e migração celular (LEBLEU; MACDONALD; KALLURI, 2007).

O colágeno tipo IV, laminina, entactina/nidogênio e perlecan são os principais componentes das MB. Além disso, outros componentes, tais como colágenos tipo XV e XVIII, agrina, SPARC/osteonectina/BM40 e fibulinas, são encontrados em menor proporção (KALLURI, 2003; LEBLEU; MACDONALD; KALLURI, 2007).

Uma característica interessante das MB é a capacidade de seus componentes de se organizarem em estruturas semelhantes a folhas. A formação dessas estruturas inicia-se com interações intermoleculares entre moléculas de colágeno IV e de laminina formando estruturas independentes (KALLURI, 2003). A formação da rede de colágeno IV é iniciada no Complexo de Golgi, onde a interação de três cadeias $\alpha$, resulta na formação de um protômero, 
que se unem formando uma estrutura em forma de rede. A rede de moléculas de laminina é iniciada, também no Complexo de Golgi, pela interação entre as cadeias $\alpha, \beta$ e $\gamma$ formando estruturas em forma de cruz que interagem entre si assumindo formas oligoméricas. $\mathrm{O}$ nidôgenio e o perlecan não formam interações intermoleculares, mas são secretadas como moléculas individuais, que se ligam aos polímeros de colágeno IV e laminina, unindo essas duas redes, formando uma estrutura estável e uniforme (LEBLEU; MACDONALD; KALLURI, 2007). A representação esquemática da formação das MB está ilustrada na figura 4. 

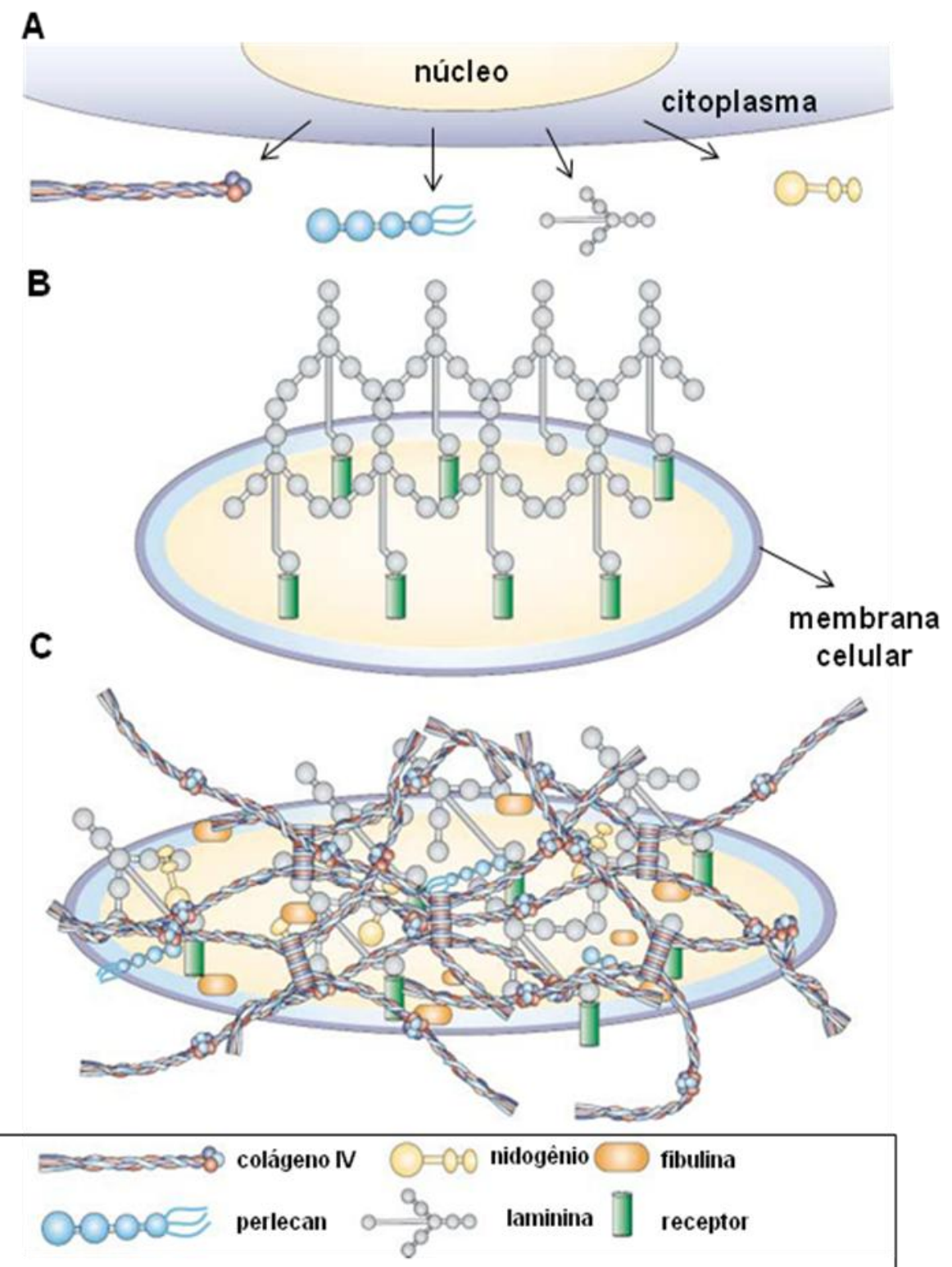

Figura 4- Representação esquemática da formação das membranas basais. A maioria das células, exceto as células imunes, produz componentes de membranas basais (MB). A) Primeiramente, as células reúnem e secretam os componentes das MB em unidades funcionais (tripla hélice de colágeno IV, trímeros de laminina, nidôgenio e perlecan). B) A polimerização de laminina é a base para a formação do esqueleto da $\mathrm{MB}$ e ocorre na superfície basolateral das células. O polímero de laminina ancora-se em receptores protéicos tais como com integrinas e distroglicanos. C) Polímeros de laminina associam-se com a rede de colágeno IV. O nidogênio forma pontes entre o polímero de laminina e a rede de colágeno IV. Outros componentes da MB interagem com a laminina e colágeno IV formando uma estrutura estável e uniforme (Adaptado de KALLURI, 2003). 
Neste trabalho, utilizamos várias abordagens que permitissem avaliar a ação de SVMPs da classe P-I e P-III em proteínas plasmáticas, matriz extracelular e células endoteliais, visando elucidar os mecanismos envolvidos no desencadeamento da hemorragia pelas SVMPs. Utilizamos ainda, um modelo de pele para estudar a distribuição tecidual das toxinas no sítio de injeção, assim como sua co-localização com componentes da membrana basal e microvasculatura. Os resultados descritos abaixo sugerem novos mecanismos envolvidos na hemorragia induzida pelas SVMPs e podem ainda explicar, pela primeira vez na literatura, as diferenças no potencial hemorrágico de SVMPs da classe P-I e P-III. 


\section{OBJETIVOS}

\subsection{Objetivo geral}

Identificar os mecanismos responsáveis pela diferença de potencial hemorrágico de SVMPs da classe P-I e P-III, comparando-as quanto à ação em células endoteliais e componentes de matriz extracelular, em modelos in vitro e ex vivo.

\subsection{Objetivos específicos}

Isolar e caracterizar uma metaloproteinase da classe P-I do veneno de Bothrops neuwiedi (BnP1) e analisá-la comparativamente com a jararagina, representante da classe P-III, avaliando os seguintes parâmetros:

- Ação em cultura de células endoteliais (HUVECs) através de ensaios de viabilidade e adesão celular, apoptose, citotoxicidade e alterações no citoesqueleto.

- Hidrólise e afinidade à proteínas plasmáticas e de matriz extracelular através de ensaios in vitro e ensaios de ligação em fase sólida.

- Co-localização, distribuição e alterações na matriz extracelular, após injeção intradérmica das toxinas na pele do dorso de animais experimentais, utilizando ensaios de histoquímica e imunofluorescência. 


\section{MATERIAL E MÉTODOS}

\subsection{Animais}

Os experimentos envolvendo animais foram realizados utilizando-se camundongos machos da linhagem BALB/c, pesando entre 18-22 g, provenientes do Biotério Central do Instituto Butantan. Os animais foram mantidos com ração e água filtrada fornecidos ad libitum, à temperatura ambiente e as condições de utilização foram reguladas pela Comissão de Ética Animal do Instituto Butantan (121/04) de acordo com as recomendações do Colégio Brasileiro de Experimentação animal (COBEA).

\subsection{Venenos}

Os venenos de Bothrops jararaca e de Bothrops neuwiedi foram obtidos do pool de venenos extraído de serpentes mantidas em cativeiro no Biotério Central do Laboratório de Herpetologia do Instituto Butantan, São Paulo-SP. As amostras de veneno foram liofilizadas e mantidas a $-20{ }^{\circ} \mathrm{C}$ até o momento do uso.

\subsection{Proteínas de matriz extracelular}

O colágeno tipo I e IV e laminina foram adquiridos comercialmente (BD Biosciences). A geração e a caracterização dos fragmentos recombinantes de colágeno tipo I foram realizadas conforme metodologia descrita anteriormente (FRANK et al., 2001). A molécula básica para a construção dos fragmentos recombinantes (FC0) consistiu de 10 repetições da região contendo a seqüência de aminoácidos GPP, responsável pela formação da tripla hélice da molécula de colágeno I. O fragmento denominado FC3 foi construído a partir do FC0, por 
meio da inserção da seqüência de aminoácidos GFPGER, sítio de ligação da integrina $\alpha_{2} \beta_{1}$. Os fragmentos FCO e FC3 foram expressos em Escherichia coli em fusão com a fibritina T4 de bacteriófagos que serviu como um domínio de enovelamento em tripla hélice. As moléculas continham uma cauda de histidina que possibilitou o isolamento em uma coluna de níquel (NiNTA-column) de acordo com metodologia previamente estabelecida. Esses processos foram realizados no laboratório do Prof. Johannes Eble, Frankfurt Universtiy Hospital, Alemanha.

\subsection{Anticorpos e sondas para imunofluorescência}

O citoesqueleto de actina foi corado com rodamina conjugada com faloidina (Molecular Probes). Como marcador nuclear, utilizamos o DAPI (4',6-amino-2phenuylindole, dihydrochloride, Molecular Probes). Os anticorpos policlonais de coelho anti-colágeno I, anticolágeno IV e anti-laminina foram obtidos comercialmente (Chemicon). Para a marcação dos vasos sangüíneos utilizou-se o anticorpo policlonal de rato anti-CD31 (BD Bioscience). Para a marcação fluorescente das toxinas, utilizou-se o fluoróforo Alexa $488^{\circledR}$ (succinimidil-ésterMolecular Probes). O anticorpo policlonal de coelho anti-jararagina foi produzido em nosso laboratório de acordo com metodologia previamente descrita (MOURA-DA-SILVA et al., 1999). O anticorpo policlonal anti-neuwiedase produzido em coelho foi gentilmente cedido pela Dra. Veridiana Rodrigues de Melo da Universidade Federal de Uberlândia. O anticorpo policlonal de camundongo anti-tubulina foi produzido no laboratório do Dr. Colin Jamora da University of California-San Diego e gentilmente cedido. Os anticorpos secundários específicos conjugados com Alexa 488 (Invitrogen) ou rodamina (Jackson ImmunoResearch) foram obtidos comercialmente. 


\subsection{Toxinas}

\subsubsection{Jararagina e jararagina-C}

A jararagina e a jararagina-C foram purificadas conforme metodologia descrita por Moura-da-Silva et al. (2003) em sistema AKTA/FPLC (Fast protein liquid chromatography, GE HealthCare). Aproximadamente $25 \mathrm{mg}$ do veneno de Bothrops jararaca foram dissolvidos em $2 \mathrm{~mL}$ de tampão Tris (hidroximetil-aminometano)-HCl 20 mM, pH 8,0 contendo $1 \mathrm{mM}$ de $\mathrm{CaCl}_{2}$ e 1,2 $\mathrm{M}$ de sulfato de amônio, pH 7,4. Em seguida, a mistura foi centrifugada a 13.000 g por 10 minutos, e o sobrenadante foi filtrado em membrana de 0,22 $\mu \mathrm{m}$ (Costar). A mistura foi aplicada a uma coluna de interação hidrofóbica Phenyl FF Hytrap (GE HealthCare), previamente equilibrada com o mesmo tampão. A fase eluente da cromatografia foi realizada num gradiente de $100 \mathrm{~mL}$ entre as concentrações de 1,2 a 0,0 M de sulfato de amônio, em Tris $20 \mathrm{mM}$ contendo $\mathrm{CaCl}_{2} 1 \mathrm{mM}$, pH 7,4. A fração III, que continha a jararagina, foi dialisada contra tampão Tris- $\mathrm{HCl} 20 \mathrm{mM}$ contendo $1 \mathrm{mM}$ de $\mathrm{CaCl}_{2}$, pH 6.8 e submetida a uma cromatografia de troca-iônica em coluna Mono-Q HR 5/5 (GE HealthCare), previamente equilibrada com tampão Tris-HCL $20 \mathrm{mM}$ contendo $1 \mathrm{mM}$ de $\mathrm{CaCl}_{2}, \mathrm{pH}$ 6.8. A fase eluente da cromatografia foi realizada num gradiente de $50 \mathrm{~mL}$ entre as concentração de 0 a $0,3 \mathrm{M}$ de $\mathrm{NaCl}$, no tampão de equilíbrio. A jararagina-C e a jararagina foram eluídas nas frações II e III, respectivamente. Frações de 0,5 mL foram coletadas num fluxo constante de $1 \mathrm{~mL} /$ minuto. As cromatografias foram monitoradas pela leitura da absorbância a $280 \mathrm{~nm}$. Para avaliar a preservação da atividade biológica da jararagina e jararagina-C foram utilizados dois parâmetros: a indução da hemorragia (3.13.1) e a inibição da agregação plaquetária (3.11), respectivamente. A pureza das proteínas isoladas foi avaliada por eletroforese em gel de poliacrilamida conforme descrito no item 3.7. 


\subsubsection{BnP1 e BnP2}

Aproximadamente $13 \mathrm{mg}$ do veneno de B. neuwiedi foram dissolvidos em $\quad 100 \mu \mathrm{L}$ de tampão Tris- $\mathrm{HCl} 20 \mathrm{mM}$, pH 8,0 contendo $1 \mathrm{mM}$ de $\mathrm{CaCl}_{2}$, centrifugados a $13000 \mathrm{~g}$ por 10 minutos e o sobrenadante aplicado a uma coluna Superdex 75 HR 10/30 (GE HealthCare), equilibrada com o mesmo tampão, acoplada a um sistema FPLC (GE HealthCare). A presença de metaloproteinases foi monitorada através da atividade fibrinolítica, conforme descrito no item 3.12.1. A fração III, que continha atividade fibrinolítica, foi submetida a uma cromatografia de troca iônica em coluna Mono-Q HR 5/5 (GE HealthCare) equilibrada com tampão Tris/ $\mathrm{HCl} 20 \mathrm{mM}$, pH 8,0 na presença de $\mathrm{CaCl}_{2} 1 \mathrm{mM}$. O primeiro pico (não retido) foi eluido em tampão de equilíbrio e a fase eluente da cromatografia foi realizada num gradiente linear de $30 \mathrm{~mL}$ entre as concentrações de 0 a $1 \mathrm{M}$ de $\mathrm{NaCl}$, no mesmo tampão. As cromatografias foram realizadas a um fluxo constante de $0,5 \mathrm{~mL} /$ minuto e frações de $0,5 \mathrm{~mL}$ foram coletadas. As cromatografias foram monitoradas pela leitura da absorbância a $280 \mathrm{~nm}$.

\subsection{Dosagem de proteínas}

A concentração protéica das amostras provenientes das cromatografias foi estimada pela leitura da densidade óptica em $280 \mathrm{~nm}$ e $260 \mathrm{~nm}$, de acordo com metodologia descrita por LAYNE (1957), utilizando-se a seguinte fórmula:

$(\mathrm{A} 280 \mathrm{~nm} \times 1,55)-(\mathrm{A} 260 \mathrm{~nm}$ $x 0,76)=m g / m L)$.

\subsection{Eletroforese em gel de poliacrilamida em condições desnaturantes (SDS-PAGE)}

O grau de pureza das toxinas foi avaliado em eletroforese em gel de poliacrilamida 12,5\%, na presença de SDS (Sodium Dodecyl Sulfate) e $\beta$-mercaptoetanol, segundo Laemmli (1970). Amostras contendo $5 \mu \mathrm{g}$ de proteína foram dissolvidas em tampão Tris- $\mathrm{HCl} 125 \mathrm{mM}$, $\mathrm{pH} 6,8$ contendo glicerol a 10\%, $\beta$-mercaptoetanol 5\%, $2 \%$ de SDS e 0,001\% de azul de 
bromofenol como marcador da corrida. Em seguida, as amostras foram fervidas por 5 minutos e aplicadas ao gel. Os padrões de peso molecular utilizados foram: $\beta$-galactosidase-116 kDa, Soroalbumina-66 kDa, Ovoalbumina-45 kDa, Lactato desidrogenase-35 kDa, endonuclease de restrição Bsp981-25 kDa, $\beta$-lactoalbumina-18.4 kDa, lisozima-14.4 kDa. O tampão de corrida foi constituído por Tris-HCl $25 \mu \mathrm{M}$, glicina $190 \mu \mathrm{M}$ e SDS a 0,1\%,pH 8,3. A eletroforese foi realizada com uma corrente de $20 \mathrm{~mA}$ até o indicador azul de bromofenol alcançar o final do gel. As proteínas foram fixadas com metanol 50\% e ácido acético $10 \%$ durante 15 a 20 minutos e corados por 1 hora com uma solução de 0,2 \% de Coomassie Blue R-250 em água e metanol na proporção de 1:1. O gel foi descorado numa solução contendo $30 \%$ de etanol e 10\% de ácido acético em água destilada.

\subsection{Inativação da atividade catalítica das toxinas}

A atividade proteolítica da jararagina e BnP1 foi inativada pelo EDTA (ácido etilenodiamino tetracético). Para tanto, $50 \mu \mathrm{L}$ de uma solução de EDTA $10 \mathrm{mM}$ foram incubados com $450 \mu \mathrm{L}$ de jararagina ou $\mathrm{BnP} 1(0,5 \mathrm{mg} / \mathrm{mL})$ por 30 minutos a $37{ }^{\circ} \mathrm{C}$.

\subsection{Marcação das toxinas com Alexa $488^{\circledR}$}

A jararagina, jararagina-C e BnP1 foram conjugadas com Alexa $488^{\circledR}$ de acordo com instruções do fabricante (Molecular Probes). Resumidamente, as toxinas foram dialisadas contra o tampão bicarbonato de sódio $0,1 \mathrm{M}$ pH 8,3, na concentração de $10 \mathrm{mg} / \mathrm{mL}$. Em seguida, $100 \mu \mathrm{L}$ de cada toxina foram adicionados à $10 \mu \mathrm{L}$ de Alexa $488^{\circledR}(10 \mathrm{mg} / \mathrm{mL}$ em DMSO- dimetilsulfóxido) e incubados por 1 hora, a temperatura ambiente, protegidas da luz. A reação foi interrompida com a adição de $50 \mu \mathrm{L}$ de cloreto de amônio $50 \mathrm{mM}$ à cada tubo. A separação das proteínas conjugadas foi realizada em coluna de gel filtração Sephadex G-25 em tampão fosfato, $\mathrm{pH}$ 8,0. A eficiência da marcação foi verificada pela leitura da absorbância a $280 \mathrm{~nm}$ e $495 \mathrm{~nm}$, de acordo com as instruções do fabricante. BSA (Bovine 
Serum Albumin) também foi conjugada ao Alexa $488^{\circledR}$, nas mesmas condições, e foi utilizada como controle negativo. A preservação da atividade biológica da jararagina, jararagina-C e BnP1 foi avaliada através da atividade hemorrágica, inibição da agregação plaquetária e atividade fibrinolítica, respectivamente.

\subsection{Seqüenciamento das proteínas isoladas}

A estrutura primária das toxinas isoladas foi parcialmente caracterizada pelo sequienciamento da região N-terminal por degradação de Edman e pela caracterização dos peptídeos internos por espectrometria de massas.

\subsubsection{Seqüenciamento da região $\mathbf{N}$-terminal}

A seqüência N-terminal da $\mathrm{BnP1}$ foi determinada por degradação de Edman, de acordo com Edman e Begg et al. (1967), usando o seqüenciador Shimadzu Protein Sequencer (PPSQ-21). Este experimento foi realizado pela Dra. Isabel Correia Batista do Laboratório de Bioquímica do Instituto Butantan.

\subsubsection{Análise por espectrometria de massas}

A digestão das amostras para análise no espectrômetro de massas foi realizada de acordo com Shevchenko et al. (1996) com modificações. Primeiramente, $5 \mu \mathrm{g}$ de BnP1 e BnP2 foram submetidas à SDS-PAGE. Após os processos de coloração e descoloração do gel, as bandas protéicas foram recortadas e transferidas para um tubo de 0,5 mL, onde foram cortadas em fragmentos menores. Em seguida, foram adicionados $400 \mu \mathrm{L}$ de uma solução de

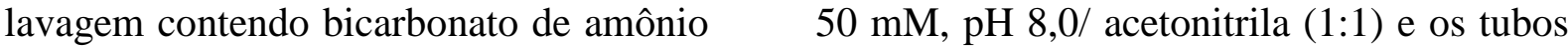
foram agitados por 15 minutos. A solução foi descartada e o processo foi repetido até a 
descoloração completa das bandas. O gel foi rehidratado com a adição de $200 \mu \mathrm{L}$ de acetonitrila por 5 minutos. As amostras foram totalmente secas por centrifugação à vácuo, reduzidas com $100 \mu \mathrm{L}$ de dithiothreitol $50 \mathrm{mM}$, por 30 minutos a $37^{\circ} \mathrm{C}$, e incubadas com 100 $\mu \mathrm{L}$ de iodoacetamida $10 \mathrm{mM}$. Em seguida, foi realizada a digestão com tripsina $(20 \mathrm{ng} / \mu \mathrm{L} \mathrm{em}$ bicarbonato de amônio $50 \mathrm{mM} \mathrm{pH} \mathrm{8.0)} \mathrm{por} 16 \mathrm{~h}$ a $37{ }^{\circ} \mathrm{C}$. As amostras foram transferidas para novos tubos e os peptídeos extraídos pela adição de $30 \mu \mathrm{L}$ de uma solução contendo ácido fórmico $10 \%$ em água/acetonitrila 1:1 seguida de agitação vigorosa em vórtex por 30 minutos. Este processo foi repetido novamente, e $80 \mu \mathrm{L}$ de amostra contendo os peptídeos foram concentrados por centrifugação a vácuo e estocados à $\quad-20{ }^{\circ} \mathrm{C}$ até análise no espectrômetro de massas.

Para a leitura das massas dos peptídeos as amostras digeridas foram submetidas a uma coluna ProteCol C18 $15 \mathrm{~cm}$ x $300 \mu \mathrm{m}$ (SGE) e os peptídeos eluídos foram submetidos a "electrospray"em um espectrômetro de massa LCQ Deca XP Plus ion trap (Thermo Finnigan). Os dados adquiridos foram manualmente interpretados e as seqüências obtidas foram submetidas ao banco de dados não redundante do NCBI usando o software Blastp de acordo com Altschul et al., 1997. Estes experimentos foram realizados pelo Dr. Richard Hemmi Valente do Departamento de Fisiologia e Farmacodinâmica, IOC-FIOCRUZ.

\subsection{Inibição da agregação plaquetária}

Amostras de sangue foram coletadas de adultos voluntários saudáveis, conforme procedimentos aprovados pelo Comitê de Ética em Pesquisa do Instituto de Saúde, SES-SP, protocolo 019/2008-SES/IS/CEPIS. Estes experimentos foram realizados em colaboração com a Dr. Maísa Esplendore Della Casa, do Laboratório de Imunopatologia do Instituto Butantan. O sangue $(9 \mathrm{~mL})$ foi coletado em tubo plástico contendo $1 \mathrm{~mL}$ de citrato de sódio $3,8 \%$, e centrifugadas a 300 g por 15 minutos a $25{ }^{\circ} \mathrm{C}$ para obtenção do plasma rico em plaquetas (PRP). Para obtenção das plaquetas lavadas, o PRP, correspondente ao sobrenadante, foi cuidadosamente coletado do tubo, diluído em EDTA 0,1\% e centrifugado por 30 minutos a $850 \mathrm{~g}$. Os pellets contendo as plaquetas foram lavados duas vezes com solução de lavagem $\left(\mathrm{NaCl} 140 \mathrm{mM}, \mathrm{NaHCO}_{3} 1 \mathrm{mM}, \mathrm{KCl} 2,5 \mathrm{mM}, \mathrm{Na} 2 \mathrm{HPO}_{4}\right.$ 0,9 mM, MgCl 2 
$32 \mathrm{mM}$, citrato trissódico 2-hidratado $22 \mathrm{mM}$, glicose 0,01 \%, BSA 0,35 \% pH 6,5), e ressuspenso na mesma solução. A concentração das plaquetas lavadas foi ajustada para 2-4 x $10^{8}$ plaquetas $/ \mathrm{mL}$. As plaquetas lavadas foram incubadas, por 5 minutos a $37{ }^{\circ} \mathrm{C}$ e sob agitação, com diferentes concentrações de jararagina e jararagina-C, e posteriormente desafiadas com as concentrações finais de $2 \mu \mathrm{g} / \mathrm{mL}$ de colágeno. A extensão da inibição da agregação foi estimada como a diminuição da porcentagem de transmissão de luz, tomando-se como $100 \%$ o valor obtido com a incubação das plaquetas lavadas com PBS (Phosphate Buffered Saline), e desafiadas com o colágeno. A transmissão de luz foi monitorada através do agregômetro (CHRONO-LOG), calibrado para 100\% da transmitância com a solução de lavagem e para $0 \%$ de transmitância com as plaquetas lavadas.

\subsection{Atividades enzimáticas}

A ação proteolítica da jararagina e $\mathrm{BnP} 1$ em componentes plasmáticos e de matriz extracelular foi testada utilizando o fibrinogênio, fibrina e laminina como substratos.

\subsubsection{Atividade proteolítica em placa de fibrina-agarose}

A atividade fibrinolítica da jararagina e BnP1 foi testada em placas de fibrinaagarose de acordo com Jespersen e Astrup (1993) com algumas modificações. Aproximadamente $10 \mathrm{mg}$ de fibrinogênio humano (Calbiochem) $(1 \mathrm{mg} / \mathrm{mL}$ de proteína coagulável) foram diluídos em $10 \mathrm{~mL}$ de tampão Tris- $\mathrm{HCl}$ 0,05 M, pH 7,3 contendo $\quad$ 0,2 M de $\mathrm{NaCl}$ e $0,05 \mathrm{M}_{\text {de }} \mathrm{CaCl}_{2}$. À esta solução foram adicionados trombina bovina (Sigma) na concentração final de $2 \mathrm{U} / \mathrm{mL}$ e $10 \mathrm{~mL}$ de uma solução de agarose low melting 2\% (Amresco) diluída no mesmo tampão. Rapidamente a mistura foi depositada em placa de petri 9,0 × 15 $\mathrm{cm}$ lisa permanecendo em temperatura ambiente sobre uma superfície previamente nivelada até a formação da rede de fibrina. Em seguida, a jararagina e $\mathrm{BnP} 1$ em concentrações entre 0,48 a $20 \mu \mathrm{M}$, foram aplicadas em orifícios previamente inseridos às placas. Após a 
incubação de 18 horas a $37{ }^{\circ} \mathrm{C}$, os halos de lise foram medidos e expressos em $\mathrm{mm}^{2}$. A atividade fibrinolítica foi medida considerando o produto dos diâmetros da área de lise $\left(\mathrm{mm}^{2}\right)$.

\subsubsection{Atividade proteolítica em substratos solúveis}

A jararagina e BnP1 foram incubadas com fibrinogênio humano em tampão Tris-HCl $20 \mathrm{mM}$ contendo $\mathrm{NaCl} 150 \mathrm{mM}$ e $\mathrm{CaCl}_{2} 1 \mathrm{mM}, \mathrm{pH}$ 8,0, na proporção de 1:10 (proteínasubstrato) por 15, 30, $60 \mathrm{~min}, 3$ e 6 horas a $37{ }^{\circ} \mathrm{C}$. Após a incubação, as toxinas foram inativadas pela adição do tampão de amostra e submetidas à eletroforese em gel de poliacrilamida $12,5 \%$ de acordo com metodologia descrita no item 3.7. As toxinas inativadas com EDTA também foram incubadas com o fibrinogênio nas mesmas condições, por 6 horas. O perfil eletroforético de degradação do fibrinogênio foi revelado por coloração do gel com Coomassie Blue R-250 e a degradação do fibrinogênio avaliada pela comparação com uma amostra de fibrinogênio incubada sem toxina por 6 horas a $37{ }^{\circ} \mathrm{C}$. A degradação da laminina foi testada nas mesmas condições descritas para o fibrinogênio, exceto pela proporção de 1:10 (proteína-substrato), tempo de incubação (30 minutos, 1, 3 e 6 horas) e a utilização de SDSPAGE $7,5 \%$.

\subsection{Atividade hemorrágica}

A atividade hemorrágica foi estimada visualmente na pele do dorso de camundongos e confirmada por microscopia intravital no músculo cremaster desses animais.

\subsubsection{Avaliação do halo hemorrágico}

A atividade hemorrágica foi determinada de acordo com Kondo et al. (1960) com algumas modificações. Amostras contendo 2,5 $\mu \mathrm{g}$ e $10 \mu \mathrm{g}$ de jararagina ou $10 \mu \mathrm{g}$ e $50 \mu \mathrm{g}$ de BnP1 foram diluídas em $50 \mu \mathrm{L}$ de PBS e injetadas intradermicamente no dorso de camundongos divididos em grupos de três animais. Animais injetados com $50 \mu \mathrm{L}$ de PBS 
foram usados como controle negativo. Após três horas, os animais foram eutanaziados em câmara de $\mathrm{CO}_{2}$ e a pele do dorso retirada para a avaliação da área hemorrágica. A atividade hemorrágica foi estimada considerando o produto entre o maior e o menor diâmetro da área da lesão $\left(\mathrm{mm}^{2}\right)$.

\subsubsection{Microscopia intravital}

Esse experimento foi realizado de acordo com Lomonte et al. (1994) com algumas modificações. Para realização do teste, camundongos divididos em grupos de três animais foram anestesiados com Hidrato de Cloral $2 \%$ (50 mg/Kg) e após a manipulação cirúrgica na bolsa escrotal para exposição do músculo cremaster, foram colocados sobre uma placa de área transparente, sobre a qual o tecido foi fixado. A placa foi montada sobre o charriot do microscópio de luz e $1 \mu \mathrm{g}$ de jararagina ou $50 \mu \mathrm{g}$ de BnP1, diluídos em $20 \mu \mathrm{L}$ de PBS, foram aplicadas topicamente sobre o músculo cremaster. As alterações foram observadas por um período de 10 minutos. O estudo do sistema microvascular do tecido transiluminado foi realizado utilizando-se um microscópio de luz (Axioskope, Carl-Zeiss), utilizando-se a objetiva de 10X/0,25Ph1. Este experimento foi realizado em colaboração com a Dra Mônica Lopes Ferreira do Laboratório Especial de Toxinologia do Instituto Butantan.

\subsection{Atividade miotóxica}

Aproximadamente $50 \mu \mathrm{g}$ da jararagina e $\mathrm{BnP} 1$ ou $10 \mu \mathrm{g}$ do veneno de Bothrops neuwiedi foram inoculados no músculo gastrocnêmio direito de camundongos divididos em grupos de cinco animais. Após 3 horas, os animais foram sacrificados e o sangue colhido pelo plexo axilar e imediatamente centrifugado a $5.000 \mathrm{~g}$, por $5 \mathrm{~min}$ a $4{ }^{\circ} \mathrm{C}$. Os animais controle receberam somente PBS no mesmo volume que as toxinas. A atividade da enzima creatina quinase foi determinada no soro dos camundongos utilizando-se o kit CK-UV cinético (Bioclin), de acordo com as instruções do fabricante. 


\subsection{Ação em cultura de células endoteliais e musculares}

A ação da jararagina e BnP1 foi comparada quanto à viabilidade e adesão celular, apoptose e citotoxicidade em cultura primária de células endoteliais de cordões umbilicais humanos (HUVECs) e em cultura de mioblastos de camundongos da linhagem C2C12.

\subsubsection{Culturas celulares}

As HUVECs foram colhidas de cordões umbilicais obtidas de parturientes atendidas pela Equipe Obstétrica do Hospital Universitário da Universidade de São Paulo (HU-USP), sob a supervisão do Dr. Carlos Alberto Maganha (Registro no Conselho de Ensino e Pesquisa do HU: 526/04), e em colaboração com a Dra. Patrícia Bianca Clissa, do Laboratório de Imunopatologia do Instituto Butantan. Após a obtenção dos cordões, as células endoteliais foram retiradas por tratamento com colagenase tipo IV (Worthington), na concentração de 1 $\mathrm{mg} / \mathrm{mL}$ em meio RPMI. Estas células foram lavadas e cultivadas em meio RPMI suplementado com $2 \mathrm{mM}$ de L-glutamina (Gibco), $100 \mathrm{UI} / \mathrm{mL}$ de penicilina (Bio-Whittaker), $100 \mu \mathrm{g} / \mathrm{mL}$ de estreptomicina (Bio-Whittaker), $1 \mathrm{mM}$ de piruvato de sódio (Gibco), contendo $10 \%$ de soro fetal bovino, acrescido de $20 \mathrm{ng}$ de bFGF (basic Fibroblast Growth Factor, Invitrogen) e $1 \mathrm{ng}$ de EGF (Endothelial Growth Factor, Invitrogen). Estas células foram cultivadas em frascos previamente revestidos com gelatina $1 \%$ e utilizadas somente até a $4^{\mathrm{a}}$ passagem, por perderem, após esse período, suas características básicas de aderência. Para a realização dos testes, $0,5 \times 10^{5}$ células/poço foram distribuídas em placas de 24 poços previamente revestidos com gelatina $1 \%$, e após 24 horas de cultura foram utilizadas nos experimentos de viabilidade, adesão celular, apoptose e citotoxicidade.

As células $\mathrm{C} 2 \mathrm{C} 12$ foram descongeladas e cultivadas em meio RPMI 1640 (Gibco) suplementado com $10 \%$ de soro fetal bovino e com $2 \mathrm{mM}$ de L-glutamina (Gibco), $2 \mathrm{mM}$ de piruvato de sódio (Gibco), $1 \mathrm{mM}$ de aminoácidos não essenciais (Gibco) e $60 \mu \mathrm{g} / \mathrm{mL}$ de gentamicina (Gibco). O cultivo foi realizado em frascos de $75 \mathrm{~mL}$, a $37{ }^{\circ} \mathrm{C}$, em atmosfera úmida com $5 \%$ de $\mathrm{CO}_{2}$. Para a diferenciação celular, $2 \times 10^{3}$ células/poço foram plaqueadas em placas de 24 poços no mesmo meio de cultura. Após atingirem condições de sub- 
confluência, usualmente entre 24 a 48 horas, o meio de cultura foi substituído pelo meio de diferenciação, o qual consistia no mesmo meio de cultura, entretanto, suplementado com apenas $1 \%$ de soro fetal bovino. Após seis dias adicionais de cultura, onde observou-se uma vasta proporção de miotúbulos alongados e multinucleados, as células foram utilizadas nos experimentos de viabilidade, adesão celular, apoptose e citotoxicidade.

\subsubsection{Ensaio de adesão e viabilidade celular}

A viabilidade e adesão celular das culturas de HUVECs e C2C12 diferenciadas tratadas com a jararagina e BnP1 foram quantificadas pela atividade da succinil desidrogenase, uma enzima mitocondrial presente somente em células vivas, cujo substrato é o MTT (3-(4,5-dimethylthiazol-2-yl)-2,5 diphenyl tetrazolium bromide). A viabilidade e adesão celular foram avaliadas após o tratamento das culturas com $800 \mathrm{nM}$ de jararagina ou BnP1 em tempos crescentes de 6, 24 e 48 horas. As culturas tratadas apenas com PBS foram utilizadas como controle negativo. Para determinar a viabilidade celular, $80 \mu \mathrm{L}$ de MTT (5mg/mL diluídos em PBS) foram adicionados à cada poço e as placas incubadas por 3 horas a $37{ }^{\circ} \mathrm{C}$ na estufa de $\mathrm{CO}_{2}$, seguida da adição de $400 \mu \mathrm{L}$ de SDS $10 \%$ em PBS 0,01 N. Após 12 horas de incubação a $37{ }^{\circ} \mathrm{C}$, a intensidade da reação foi determinada pela leitura da densidade óptica a $570 \mathrm{~nm}$ em um leitor de ELISA (Enzyme-linked immunosorbent assay-Multiskan EX, Labsystems). Para avaliar a adesão celular, os poços foram lavados por duas vezes com PBS antes do estabelecimento do mesmo protocolo descrito para a determinação da viabilidade celular. Os experimentos foram feitos em triplicata e repetidos três vezes.

\subsubsection{Apoptose}

A apoptose foi avaliada através da análise do conteúdo de DNA (Deoxyribonucleic Acid) das células por citometria de fluxo como descrito por Nicoletti et al. (1991). As culturas celulares foram tratadas com $800 \mathrm{nM}$ de jararagina e BnP1 em tempos crescentes de 6, $24 \mathrm{e}$ 48 horas. Neste ensaio, foram utilizadas as células descoladas presentes no sobrenadante e 
aquelas que ainda permaneciam aderidas a placa. Inicialmente, os sobrenadantes foram coletados e em seguida os poços foram tripsinados com uma solução de tripsina/EDTA (Gibco), para o descolamento das células aderidas. Em seguida, as amostras foram centrifugadas a 240 x g por 5 minutos a $4{ }^{\circ} \mathrm{C}$ e incubadas por 1 hora com uma solução hipotônica contendo $0,1 \%$ de citrato de sódio, $0,1 \%$ de triton-X 100 e $50 \mu \mathrm{g} / \mathrm{mL}$ de iodeto de propídio. As amostras foram analisadas por citometria de fluxo (FacsCalibur- Becton \& Dickison) e os resultados foram representados pela porcentagem de células correspondentes à fase sub-G1, isto é, a porcentagem de células que apresentam o conteúdo de DNA fragmentado. Foram realizados três experimentos independentes em triplicata, sendo que a média e o desvio padrão da porcentagem das células presentes da fase sub-G1 foram representados nos gráficos. A análise de citometria de fluxo foi realizada no laboratório do Dr. Gustavo Amarante Mendes do Departamento de Imunologia-ICB/USP.

\subsubsection{Citotoxicidade direta}

As culturas celulares foram tratadas com $800 \mathrm{nM}$ de jararagina e BnP1 em tempos crescentes de 6, 24 e 48 horas. Após os tempos de tratamento, as placas foram centrifugadas a $240 \mathrm{x}$ g por 10 minutos a $4{ }^{\circ} \mathrm{C}$. A citotoxicidade foi avaliada pela atividade da enzima lactato desidrogenase $(\mathrm{LDH})$ liberada no sobrenadante das culturas celulares após a centrifugação das placas, usando o kit LDH-FS (DiaSys-Diagnostic Systems International) de acordo com as instruções do fabricante.

\subsubsection{Ação no citoesqueleto de HUVECs}

Para a avaliação do citoesqueleto, $10^{4}$ células HUVECs foram cultivadas em chamber slides system (NUNC) previamente revestidas com $30 \mu \mathrm{g} / \mathrm{mL}$ de fibronectina humana (Invitrogen). Após 24 horas de adesão, as células foram tratadas com $800 \mathrm{nM}$ de jararagina ou BnP1 por 10 minutos a $37{ }^{\circ} \mathrm{C}$ na estufa de $\mathrm{CO}_{2}$. Células tratadas com PBS foram utilizadas 
com controle negativo. Alternativamente, as células foram tratadas com as toxinas com atividade catalítica inibida por EDTA. Para a marcação do citoesqueleto de actina, as células foram lavadas com tampão contendo $50 \mathrm{mM}$ de HEPES (N-2-hydroxyethylpiperzine-N1-2ethanesulfonic acid) e $150 \mathrm{mM} \mathrm{NaCl}, \mathrm{pH}$ 7,4, fixadas em formaldeído 3,7\% por 10 minutos a temperatura ambiente, lavadas sucessivamente em PBS e bloqueadas por 1 hora em solução de bloqueio (triton X-100 1\%, soro normal de coelho 5\%, BSA 0,5\%, glicina 0,5\%, gelatina de pele de peixe $0,5 \%$ ). Em seguida, as células foram incubadas com rodamina-faloidina (1:100-Invitrogen) por 2 horas à temperatura ambiente. A coloração do núcleo foi realizada com DAPI (1:1000). Para marcação dos microtúbulos, as células foram lavadas com tampão HEPES, fixadas em metanol $100 \%$ por 10 minutos a $-20{ }^{\circ} \mathrm{C}$, lavadas sucessivamente em PBS e bloqueadas por 1 hora em solução de bloqueio. Em seguida, as células foram incubadas com anticorpo anti-tubulina $(1: 100)$, por 24 horas à $4^{\circ} \mathrm{C}$, com posterior incubação com o anticorpo secundário específico conjugado com Alexa 488. As lâminas foram montadas com anti-fading (Invitrogen) e analisadas em microscópio confocal (LSM-510-Meta, Zeiss) do Instituto Butantan.

\subsection{Ensaio de adesão em fase sólida}

A avaliação da interação das SVMPs ao fibrinogênio, colágeno I, IV e laminina foi realizada de acordo com metodologia descrita por Tanjoni et al. (2003) com algumas modificações. Placas de microtitulação de 96 orifícios (NUNC) foram sensibilizadas por 18 horas, a $4{ }^{\circ} \mathrm{C}$ em câmara úmida, com $100 \mu \mathrm{L}$ por poço das seguintes soluções: fibrinogênio humano e laminina na concentração de $10 \mu \mathrm{g} / \mathrm{mL}$ diluídos em tampão fosfato, pH 7,4, colágeno tipo I e IV, na concentração de $10 \mu \mathrm{g} / \mathrm{mL}$ em ácido acético 0,02 N e $\mathrm{HCl}$ 0,05N, respectivamente, fragmentos recombinantes do colágeno I (FCO e FC3) na concentração de 8 $\mu \mathrm{g} / \mathrm{mL}$ em tampão em Tris-salina, pH 7.4. Após este período, as placas foram lavadas com Tris-salina (0,1 M de Tris em 0,15 M de NaCl, pH 7,5) e, em seguida, bloqueadas por 2 horas a $37{ }^{\circ} \mathrm{C}$ com uma solução de Tris-salina contendo $2 \%$ de leite desnatado (200 $\mu$ l por poço). Em seguida, toxinas diluídas em Tris-Salina contendo $2 \%$ de leite desnatado (100 $\mu \mathrm{L} /$ poço) foram adicionadas às placas e incubadas por 1 hora a $37{ }^{\circ} \mathrm{C}$ em câmara úmida. As placas 
então foram lavadas com Tris-salina e em seguida, incubadas por 1 hora a $37{ }^{\circ} \mathrm{C}$ com anticorpo policlonal de coelho anti-jararagina (para a jararagina, jararagina-C) ou policlonal de coelho anti-neuwiedase (para a BnP1) diluídos 1:100 na solução em Tris-Salina contendo $2 \%$ de leite desnatado (100 $\mu \mathrm{L} /$ poço). Após mais um ciclo de lavagens, as placas foram incubadas com anticorpos de ovelha anti-IgG de coelho, marcados com peroxidase (Sigma), diluídos 1:2000 em Tris-salina/2\% de Leite desnatado (100 $\mu \mathrm{L} /$ poço). Após um novo ciclo de lavagens, a reação foi revelada, adicionando-se $100 \mu \mathrm{l}$ por poço do substrato da enzima $(0,7$ $\mathrm{mg}$ de OPD - o-Fenilenodiamina/mL em tampão citrato 0,2 $\mathrm{M}, \mathrm{pH} 5,0$, e 0,06\% $\mathrm{H}_{2} \mathrm{O}_{2}$ ). A reação foi interrompida pela adição de $\mathrm{H}_{2} \mathrm{SO}_{4}$ a $30 \%$

(50 $\mu \mathrm{l} /$ poço). A intensidade da reação foi determinada pela leitura da densidade óptica a $492 \mathrm{~nm}$ em um leitor de ELISA (Multiskan EX, Labsystems). Nos experimentos das figuras 18 e 19, a jararagina ligada às placas sensibilizadas com o colágeno foi fixada com glutaraldeído $2.5 \%$ em Tris-salina tamponada com HEPES e o complexo antígeno/anticorpo foi revelado com anticorpos antiIgG de coelho conjugado com fosfatase alcalina utilizando-se uma solução de NBT (NitroBlue Tetrazolium Chloride) na concentração de $50 \mathrm{mg} / \mathrm{mL}$ em $70 \%$ de dimetilformamida e BCIP (5-Bromo-4-Chloro-3'-Indolyphosphate p-Toluidine Salt) na concentração de $50 \mathrm{mg} / \mathrm{mL}$ em $100 \%$ de formamida, substratos da enzima fosfatase alcalina (Sigma). A leitura foi feita em $405 \mathrm{~nm}$ em um leitor de ELISA (Multiskan EX, Labsystems). Alternativamente, as placas foram revestidas com o colágeno desnaturado por aquecimento e carboximetilação e o mesmo protocolo descrito acima foi realizado.

\subsection{Atividades biológicas da jararagina complexada ao colágeno}

A atividade catalítica da jararagina complexada com o colágeno foi avaliada através da atividade fibrinolítica. Para tanto, $10 \mu \mathrm{g}$ de jararagina foram incubados com o colágeno tipo I na proporção de 1:1, 1:3 e 1:5 (proteína-substrato), por 30 minutos a $37^{\circ} \mathrm{C}$. Em seguida, as amostras foram testadas quanto a atividade fibrinolítica utilizando-se placas de fibrinaagarose conforme descrito no item 3.12.1. Para a atividade hemorrágica, $1 \mu \mathrm{g}$ de jararagina foi incubado com colágeno I ou colágeno IV na proporção de 1:10 e 1:20 (proteína-substrato), nas mesmas condições citadas acima. A ação hemorrágica foi avaliada após 15 minutos da 
injeção intradérmica das amostras na pele do dorso de camundongos, conforme descrito no item 3.13.1. Animais injetados apenas com $1 \mu \mathrm{g}$ de jararagina e com $20 \mu \mathrm{g}$ de colágeno I/IV foram usados como controle positivo e negativo, respectivamente.

\subsection{Ação na pele do dorso de camundongos}

A ação da jararagina e BnP1 na pele de camundongos foi comparada, em experimentos ex vivo, utilizando-se a análise histológica, ensaios de imunofluorescência e experimentos de co-localização das toxinas com componentes de matriz extracelular.

\subsubsection{Coleta e processamento do material para microscopia de Luz}

Grupos de três animais foram depilados no dorso para a injeção intradérmica de $10 \mu \mathrm{g}$ de jararagina e duas doses de BnP1 $(5 \mu \mathrm{g}$ e $50 \mu \mathrm{g})$, diluídos em $20 \mu \mathrm{L}$ de PBS. Animais controle receberam somente $20 \mu \mathrm{L}$ de PBS. Após 15 minutos e 1 hora, os animais foram sacrificados e a pele cuidadosamente retirada e fixada em metacan (10\% de ácido acético, $60 \%$ de álcool metilíco, $30 \%$ de clorofórmio) por 3 horas a temperatura ambiente. Em seguida, os tecidos foram desidratados em álcool etílico $100 \%$ por 30 minutos, 4 vezes seguidas. Os tecidos foram mergulhados em xilol por 20 minutos, 3 vezes seguidas e as amostras foram incluídas em resina Paraplast-Histosec (Merck). Cortes com $5 \mu \mathrm{m}$ de espessura foram aderidos à lâminas de vidro previamente revestidas por poli- L- Lisina e posteriormente utilizados para procedimentos de histoquímica e imunofluorescência. Para o processo de desparafinização, as lâminas foram mergulhadas em xilol por 30 minutos, duas vezes seguidas, e em seguida foram hidratadas em concentrações decrescentes de álcool etílico. Algumas amostras foram lavadas em água destilada por 10 minutos e coradas com uma solução de hematoxilina e eosina para os estudos morfológicos dos tecidos. Outras amostras foram submetidas à reação histoquímica para detecção de colágenos e ensaios de imunofluorescência. 


\subsubsection{Histoquímica para detecção de colágenos fibrilares}

A reação histoquímica pelo picrossirius embora não seja capaz de distinguir os diferentes tipos genéticos de colágeno permite a identificação específica dos colágenos fibrilares como um todo. As moléculas do corante interagem estequiometricamente com moléculas de colágeno nas fibrilas colágenas, dando a elas uma coloração vermelha característica (MONTES; JUNQUEIRA, 1991). Para tanto, os cortes foram hidratados em álcoois de graduação decrescente até a água e permaneceram na solução de picrossirius por 20 minutos e em seguida em água corrente por 10 minutos. Após esse processo, as lâminas foram contra coradas pela hematoxilina por 3 minutos, seguida pela lavagem em água corrente por 10 minutos. Procedeu-se então a desidratação dos cortes em série alcoólica de graduação crescente, diafanização e montagem.

\subsubsection{Biodistribuição das SVMPs e co-localização com o colágeno IV}

A biodistribuição das toxinas foi avaliada na pele de camundongos após a injeção intradérmica de $10 \mu \mathrm{g}$ de jararagina conjugada com Alexa 488 (jar-Alexa488), 5 ug de jararagina-C conjugada com Alexa 488 (jarC-Alexa488) e $5 \mu \mathrm{g}$ e $50 \mu \mathrm{g}$ de BnP1 conjugada com Alexa488 (BnP1-Alexa488), diluídas em $20 \mu \mathrm{L}$ de PBS. Animais controle receberam somente $10 \mu \mathrm{g}$ de BSA conjugada com Alexa488 (BSA-Alexa488). Após 15 minutos, os animais foram sacrificados, e o local correspondente à injeção foi cuidadosamente retirado e incluído em OCT (Optimal cutting temperature), para obtenção de cortes congelados com 5 $\mu \mathrm{m}$ de espessura que foram armazenados a $-4{ }^{\circ} \mathrm{C}$. Para realização dos ensaios de imunofluorescência, as lâminas foram fixadas em formaldeído 3,7\% por 10 minutos, e após sucessivas lavagens em PBS, foram bloqueadas (triton X-100 1\%, soro normal de coelho 5\%, BSA $0,5 \%$, glicina $0,5 \%, 0,5 \%$ gelatina de pele de peixe) e incubadas por 12 horas à $4{ }^{\circ} \mathrm{C}$ com o anticorpo anti-CD31 (1:40), um marcador seletivo de vasos sanguíneos ou anticolágeno IV (1:40), marcador da membrana basal. Em seguida, as lâminas foram lavadas e incubadas por duas horas à temperatura ambiente com o anti-IgG de rato conjugado com 
TRITC (Tetramethyl Rhodamine Isothiocyanate,1:500) ou anti-IgG de coelho conjugado com TRITC (1:100). As lâminas foram montadas com anti-fading (Invitrogen) e analisadas em microscopio confocal (LSM-510-Meta, Zeiss). Os experimentos foram realizados 3 vezes, utilizando-se diferentes animais e as lâminas avaliadas em 10 campos diferentes.

\subsubsection{Detecção dos componentes da membrana basal}

Para a imunodetecção dos componentes de matriz extracelular, as lâminas processadas conforme descrito no item 3.18.1, foram imersas em xilol e reidratadas com concentrações decrescentes de etanol. Os sítios imunogênicos foram expostos pelo tratamento enzimático das amostras de pele com pepsina de porco (Sigma) na concentração de $4 \mathrm{mg} / \mathrm{mL}$ em ácido acético 0,5 N. Para a marcação do colágeno I, as lâminas foram incubadas por 30 minutos, a $37{ }^{\circ} \mathrm{C}$. Para o colágeno IV e laminina, o material foi incubado por 10 minutos, a temperatura ambiente. Após sucessivas lavagens em PBS, as lâminas foram bloqueadas com uma solução contendo BSA $10 \%$ em PBS e soro normal de cabra, na proporção de 1:1, por 1 hora, a temperatura ambiente. O material foi, então, incubado com os anticorpos anti-colágeno IV (1:40) ou anti-laminina (1:40), por 18 horas, a $4{ }^{\circ} \mathrm{C}$. Após esse período, as lâminas foram novamente lavadas em PBS e incubadas com anti-IgG de coelho conjugado com Alexa 488 (1:1000), por 90 minutos, a temperatura ambiente. A coloração do núcleo foi realizada com DAPI (1:1000). As lâminas foram montadas com anti-fading (Invitrogen) e analisadas em microscópio confocal (LSM-510-Meta, Zeiss).

\subsection{Análise estatística}

Os resultados obtidos foram expressos como média \pm desvio padrão e avaliados estatisticamente pela análise paramétrica através do teste t-Student. Em todos os cálculos foi fixado o nível de significância de $0,5 \%(\mathrm{p}<0,05)$. 


\section{RESULTADOS}

\subsection{Isolamento e caracterização das SVMPs}

A primeira etapa deste trabalho consistiu no isolamento da jararagina, utilizada como modelo de SVMP da classe P-III, e da BnP1, escolhida como modelo de SVMP da classe P-I. $\mathrm{O}$ isolamento da jararagina seguiu os métodos já padronizados em nosso laboratório (MOURA-DA-SILVA et al., 2003). A BnP1 consiste em uma nova SVMP da classe P-I, isolada e caracterizada neste trabalho.

\subsubsection{Isolamento da jararagina, uma SVMP da classe P-III, do veneno de Bothrops jararaca}

O fracionamento do veneno de B. jararaca em coluna de interação hidrofóbica Phenyl FF Hytrap, resultou em 3 frações principais denominadas de I a III (Figura 5A). A fração III, que continha uma banda principal em torno de $52 \mathrm{kDa}$ (Fig. 5B), foi submetida a uma nova cromatografia em coluna de troca iônica Mono-Q HR 5/5. Esse procedimento resultou em 3 picos principais (Figura 5C). Os picos 2 e 3 mostraram perfil eletroforético com uma única banda protéica em torno de $28 \mathrm{kDa}$ e $52 \mathrm{kDa}$, massas moleculares referentes à jararagina-C e jararagina, respectivamente (Figura 5D). O rendimento total ao final do processo cromatográfico foi de $1 \%$ para a jararagina-C e de $4 \%$ para a jararagina.

A preservação da atividade biológica das toxinas foi avaliada pela atividade hemorrágica e a inibição da agregação plaquetária. A injeção de $10 \mu \mathrm{g}$ da jararagina no dorso de camundongos resultou em uma área hemorrágica de $26 \mathrm{~mm}^{2}$ e a concentração de $200 \mathrm{nM}$ foi capaz de abolir totalmente a agregação plaquetária induzida pelo colágeno. A jararagina-C inibiu totalmente a agregação plaquetária induzida pelo colágeno na concentração de $450 \mathrm{nM}$. 
A
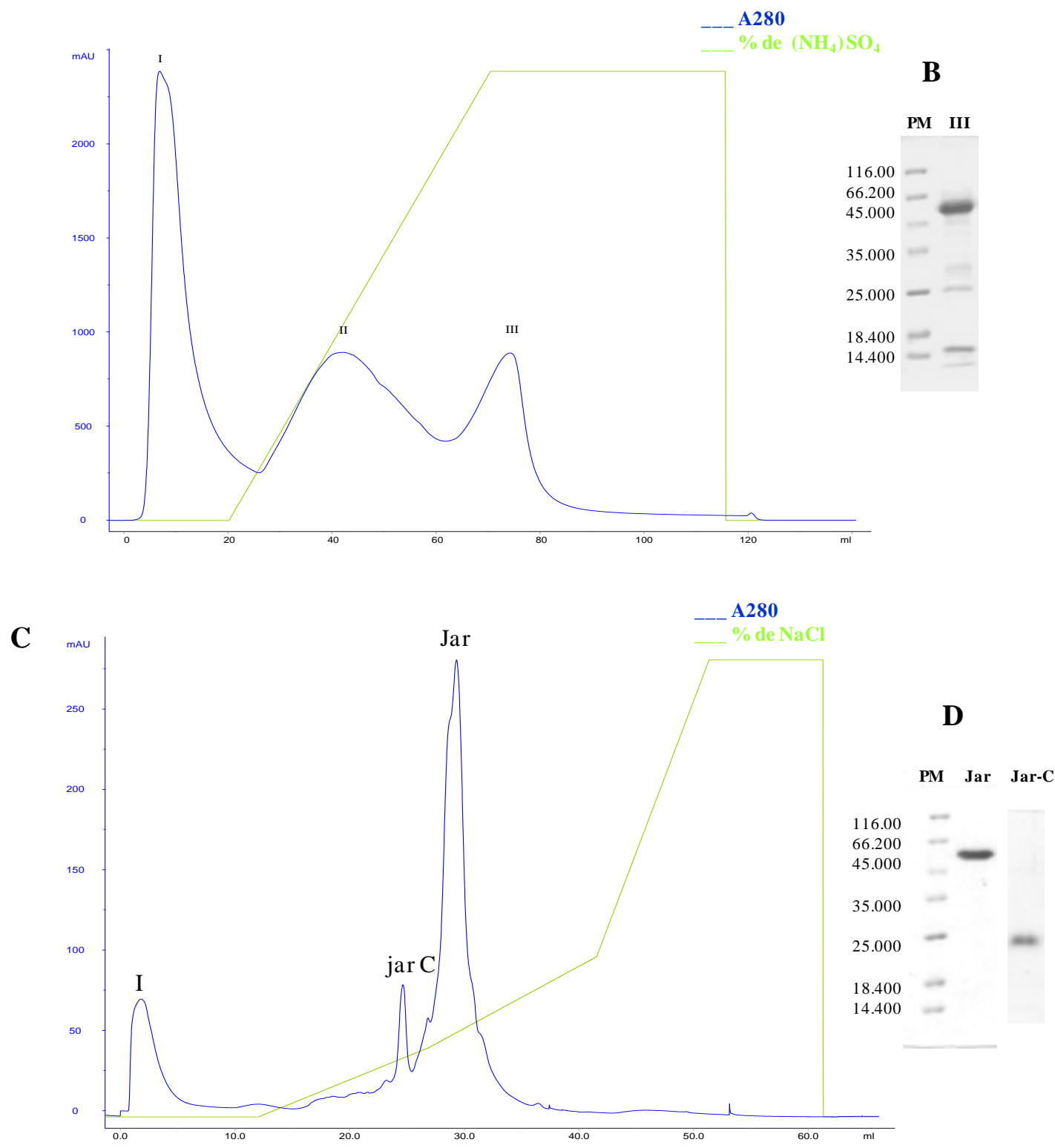

Figura 5- Purificação da jararagina e jararagina-C em sistema FPLC. A- Perfil cromatográfico de 25 $\mathrm{mg}$ do veneno de $B$. jararaca em coluna de interação hidrofóbica Phenil FF Hytrap. A coluna foi equilibrada em tampão Tris- $\mathrm{HCl} 20 \mathrm{mM}$ contendo $\mathrm{CaCl}_{2} 1 \mathrm{mM}$ e sulfato de amônio $1,2 \mathrm{M}$, $\mathrm{pH} 7,4$. A fase eluente da cromatografia foi realizada num gradiente de $100 \mathrm{~mL}$ entre as concentrações de 1,2 a $0 \mathrm{M}$ de sulfato de amônio no mesmo tampão. B- SDS-PAGE a 12,5\% da fração III, que contém a jararagina C-Cromatografia de troca iônica da fração III em coluna Mono-Q HR 5/5, equilibrada em tampão Tris/HCl $20 \mathrm{mM}, \mathrm{pH} 8,0$ na presença de cloreto de cálcio $1 \mathrm{mM}$. A fase eluente da cromatografia foi realizada num gradiente de 50 $\mathrm{mL}$ entre as concentrações de 0 a $0,3 \mathrm{M}$ de $\mathrm{NaCl}$ no tampão de equilíbrio. Frações de $0,5 \mathrm{~mL}$ foram coletadas num fluxo constante de $1 \mathrm{~mL} /$ minuto. As cromatografias foram monitoradas pela leitura da absorbância a $280 \mathrm{~nm}$. D- SDS-PAGE a 12,5\% de $5 \mu \mathrm{g}$ da jararagina e jararagina-C. PM: padrão de massa molecular. 


\subsubsection{Isolamento de uma SVMP da classe P-I do veneno de Bothrops neuwiedi}

O veneno de $B$. neuwiedi foi primeiramente submetido a uma gel filtração em coluna Superdex 75 HR 10/30. Este fracionamento resultou em seis frações principais denominadas de I a VI (Figura 6A). Com o objetivo de localizar frações que continham atividade metaloproteinase, foi realizada uma triagem através da atividade fibrinolítica em placa de fibrina-agarose (Tabela 01). Além disso, as frações foram analisadas por SDS-PAGE para avaliação da massa molecular (Figura 6B). Baseando-se nesses parâmetros, a fração III foi selecionada e submetida a uma cromatografia em coluna de troca iônica Mono-Q HR 5/5, pH 7,8, que resultou em duas frações majoritárias, IIIa e IIIb que conservaram a atividade fibrinolítica (Figura 6C). O rendimento total das frações IIIa e IIIb ao final do processo cromatográfico foi de $4,5 \%$ e $0,54 \%$, respectivamente. A eletroforese em gel de poliacrilamida em condições redutoras mostrou que as frações IIIa e IIIb apresentavam-se como bandas únicas, com massa molecular aparente de $23.6 \mathrm{kDa}$ (Figura 6D).

O seqüenciamento das frações isoladas foi realizado por espectrometria de massas e a determinação da seqüência N-terminal por degradação de Edman. Usando essas duas metodologias, aproximadamente $40 \%$ de IIIa e $34 \%$ de IIIb foram seqüenciadas. De acordo com a figura 7, as frações IIIa e IIIb exibem um alto grau de similaridade entre si, diferindo apenas na posição 30, onde uma asparagina foi substituída por um ácido aspártico. A similaridade das frações IIIa e IIIb com outras SVMPs também foi verificada usando o software Blastp (ALTSCHUL et al., 1997). Esta análise indicou uma alta similaridade com a insularinase, uma metaloproteinase da classe P-II isolada do veneno de B. insularis (gi $52426579,91 \%$ de identidade), e com as metaloproteinases tipo II e I isoladas do veneno de B. asper (gi 82466485, $82 \%$ de identidade e gi 82466487, 82\% de identidade, respectivamente) e com a BaP1, uma P-I isolada de B. asper (gi 46395679, 81\% identidade). A similaridade com a neuwiedase, originalmente isolada do veneno de B. neuweidi (gi 6760464), foi somente de 69\%, sugerindo que as frações IIIa e IIIb tratavam-se de novas toxinas, denominadas então de $\mathrm{BnP} 1$ e $\mathrm{BnP} 2$, respectivamente. As toxinas isoladas apresentaram somente $44 \%$ de similaridade com a jararagina. Considerando-se a massa molecular, a presença de atividade catalítica e a similaridade com outras SVMPs, BnP1 e BnP2 foram caracterizadas como SVMPs da classe P-I e a BnP1 foi então escolhida como modelo de estudo nesse trabalho. 
Tabela 1- Atividade fibrinolítica das frações do veneno de B. neuwiedi obtidas da cromatografia em gel filtração.

\begin{tabular}{c|c}
\hline Frações * $^{*}$ & Atividade fibrinolítica** $\left(\mathbf{m m}^{2}\right)$ \\
\hline I $(50,45 \mathrm{kDa})$ & 22,5 \\
\hline II $(50,45,35 \mathrm{kDa})$ & ND \\
\hline III $(25 \mathrm{kDa})$ & 17 \\
\hline IV $(25,14 \mathrm{kDa})$ & 25 \\
\hline V $(25,14 \mathrm{kDa})$ & 5,7 \\
\hline VI $(14 \mathrm{kDa})$ & -- \\
\hline
\end{tabular}

* massas moleculares das bandas protéicas principais (SDS-PAGE)

** $10 \mu \mathrm{g}$ de amostra

ND: não determinado

--: sem atividade fibrinolítica 
A

B

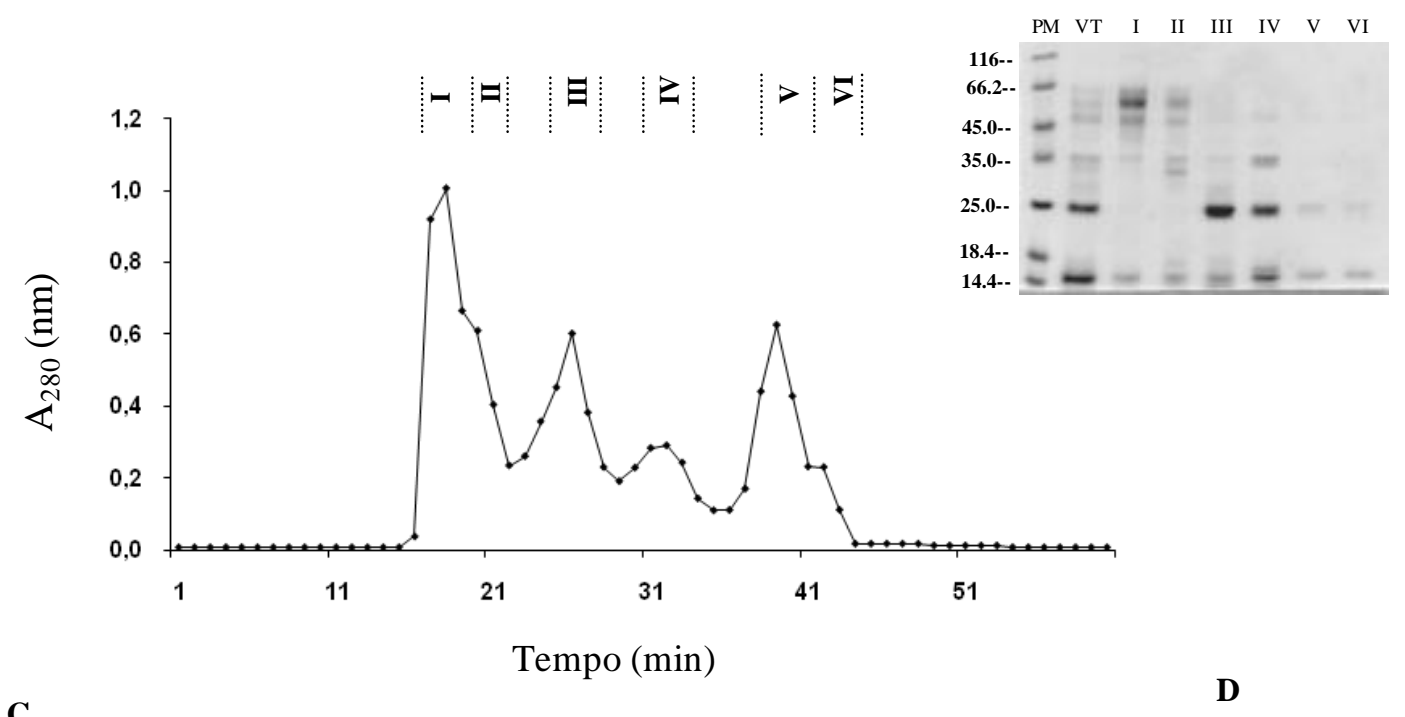

C

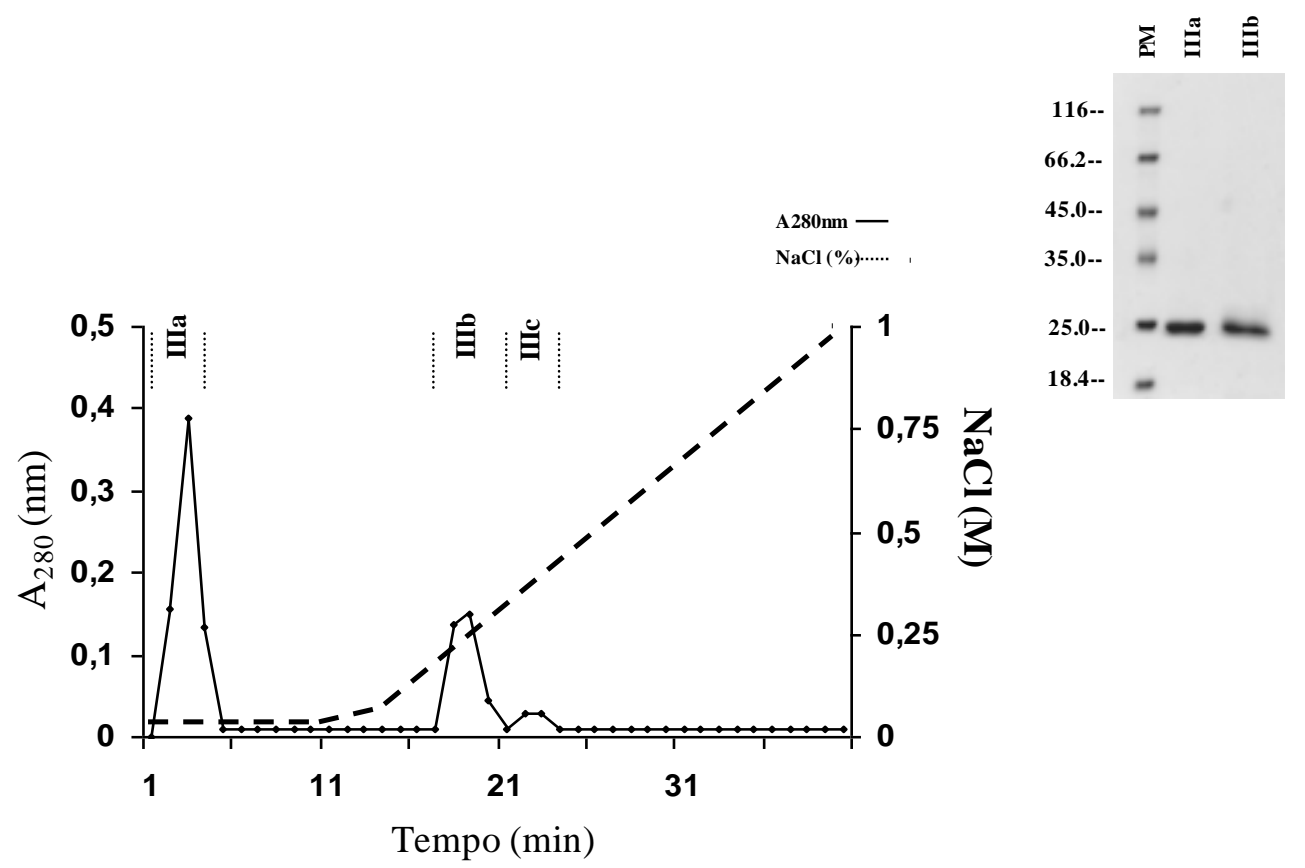

Figura 6- Purificação da $\mathrm{BnP} 1$ e $\mathrm{BnP} 2$ em sistema FPLC. A- Perfil cromatográfico de $13 \mathrm{mg}$ do veneno de $B$. neuwiedi em coluna Superdex 75 HR 10/30, equilibrada com tampão Tris$\mathrm{HCl} 20 \mathrm{mM}$ contendo $1 \mathrm{mM}$ de $\mathrm{CaCl}_{2}$, pH 8,0. B- SDS-PAGE a 12,5\% das frações obtidas na gel filtração (I-VI). C- Cromatografia de troca iônica da fração III em coluna Mono-Q HR 5/5, equilibrada em tampão Tris/HCl $20 \mathrm{mM}$, pH 8,0, na presença de cloreto de cálcio $1 \mathrm{mM}$. A fase eluente da cromatografia foi realizada num gradiente de concentração de 0 a $100 \%$ de $\mathrm{NaCl} 1 \mathrm{M}$, em $30 \mathrm{~mL}$, no tampão de equilíbrio. Frações de $0,5 \mathrm{~mL}$ foram coletadas num fluxo constante de $1 \mathrm{~mL} /$ minuto. As cromatografias foram monitoradas pela leitura da absorbância a $280 \mathrm{~nm}$. D- SDS-PAGE a 12,5\% de $5 \mu \mathrm{g}$ de BnP1 (IIIa) e BnP2 (IIIb). PM: padrão de massa molecular. VT: veneno total de B. neuwiedi. 
BnP1

BnP 2

Insularinase

Type II (Ba)

BaP1

Type I (Ba)

Neuwiedase

Jararagina

BnP1

BnP2

Insularinase

Type II (Ba)

BaP1

Type I (Ba)

Neuwiedase

Jararagina

BnP1

BnP2

Insularinase

Type II (Ba)

BaP1

Type I (Ba)

Neuwiedase

Jararagina

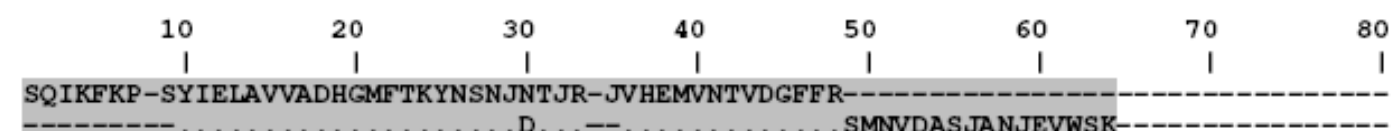

E.Q. S. - R. . . . . . . . . . . . . I. TR. . . . . LN . . . . . . . L . L. . . KDLIKVEKDSSKTLTS

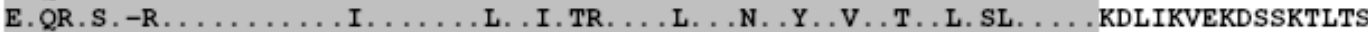

- .QR.S. - R. . . . . . . . I. . . . . L. TI. TR. . . L. . N. . . . VD. H. PL. . L. . . QDLIKVQKDSSKTLKS

E.QR.S. - R. . . . . . . I. . . . . L. TI. TR. . . L . . . . . . VD. H.PL . L. . . QDLIKVQKDSSKTLKS

Q.RF.PQ-R. . . VI . . RR.Y. . . . DS. KI.TR . . L . . . N . . . . . . . L . . L . . . KDLIKVEKDSSKTLTS

E. QRYD.YK. . FF. .V.Q. TV. .N. GDL. KIKARMY. LA. I . NEI . YLYMHVALVGL. I . NGDKITVKPDVDYTLNS

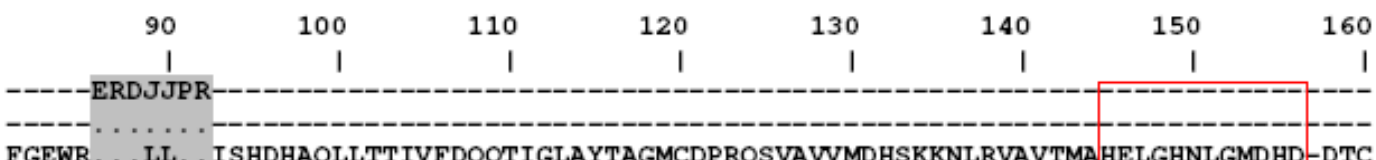
FGEWR. . . LL . ISHDHAQLLTTIVFDNYVIGITEFGKMCDPKLSVGVVRDHSEINLQVAVAMAHELGHNLGMYHD GNQC FGEWR. . . LL . . ISHDHAQLLTAVVFDGNTIGRAYTGGMCDPRHSVGVVRDHSKNNLWVAVTMAHELGHNLGIXHDIGSC FGEWR. . . LL . ISHDHAQLLTAVVFDGNTIGRAYTGGMCDPRHSVGVVRDHSKNNLWVAVTMAHELGHNLGIHHDTGSC FGEWR. . . LLR . KSHDNAQLLTAIDFNGNTIGRAYLGSMCNPKRSVGIVQDHSP INLLVGVTMAHELGHNLGMEHD GKDC FAEWRKT . LLT . KKHDNAQLLTAIDFNGPT IGYAYIGSMCHPKRSVGIVQDYSP INLVVAVIMAHEMGHNLGIHHDTGSC

\begin{tabular}{l} 
I \\
\hline 170
\end{tabular}

Figura 7- Alinhamento das sequiências da BnP1 e BnP2 com outras SVMPs. As seqüências parciais de BnP1 e BnP2 foram obtidas por espectrometria de massas (MALDI TOF/TOF) e degradação de Edman (resíduos sublinhados) e alinhadas com outras SVMPs usando o programa CLUSTAL W (COMBET et al., 2000). Os traços (--) indicam espaços inseridos para facilitar o alinhamento. Os resíduos com identidade com as outras SVMPs estão representados por pontos (...).O sítio ligante de zinco das SVMPs está destacado pelo retângulo aberto. Estão destacadas nos retângulos cinzas as regiões cobertas pelos seqüenciamentos, onde $\mathrm{J}$ corresponde a Ile ou Leu. 


\subsection{Caracterização das atividades hemorrágica e miotóxica}

A comparação da atividade hemorrágica da jararagina e BnP1 foi realizada por meio da injeção intradérmica das toxinas no dorso de camundongos e por microscopia intravital. A injeção intradérmica de $2.5 \mu \mathrm{g}$ de jararagina induziu um grande halo hemorrágico, que se tornou mais evidente quando a dose $10 \mu \mathrm{g}$ de jararagina foi usada. Por outro lado, a dose de $10 \mu \mathrm{g}$ de BnP1 não foi capaz de induzir hemorragia. Um pequeno halo hemorrágico foi observado quando a dose de $50 \mu \mathrm{g}$ de $\mathrm{BnP} 1$ foi injetada (Figura 8A). Resultados semelhantes foram observados em microscopia intravital, onde a administração tópica de $50 \mu \mathrm{g}$ de $\mathrm{BnP} 1$ não induziu hemorragia na microvasculatura do músculo cremaster. No entanto, $1 \mu \mathrm{g}$ de jararagina induziu um evidente extravasamento dos componentes sangüíneos e promoveu um aumento do rolamento de leucócitos na parede de vênulas pós-capilares. Nenhuma alteração nas fibras musculares foi observada após a administração de jararagina ou BnP1 (Figura 8B). Esses resultados mostraram claramente a diferença de potencial hemorrágico entre as toxinas, indicando que as mesmas são bons modelos para nosso trabalho. Uma vez que a atividade miotóxica da neuwiedase foi anteriormente descrita (RODRIGUES et al., 2001), esse experimento foi incluído nesse trabalho. A atividade miotóxica da jararagina e BnP1 foi analisada pela dosagem plasmática da enzima creatina quinase em animais inoculados com 50 $\mu \mathrm{g}$ destas toxinas, como mostrado na figura 9. Comparando-se com o controle dos animais inoculados somente com PBS, notou-se um pequeno aumento na liberação de creatina quinase nas amostras correspondentes às duas toxinas, mas sem diferença estatisticamente significante entre elas e o controle. Os níveis de CK induzidos pelo veneno de B. neuwiedi foram significativamente maiores que nos animais injetados apenas com PBS. A ausência de atividade miotóxica da $\mathrm{BnP} 1$ confirma nossas observações iniciais de que essa toxina não é a neuwiedase, mas sim uma nova SVMP da classe P-I presente no veneno de B. neuwiedi. 
A

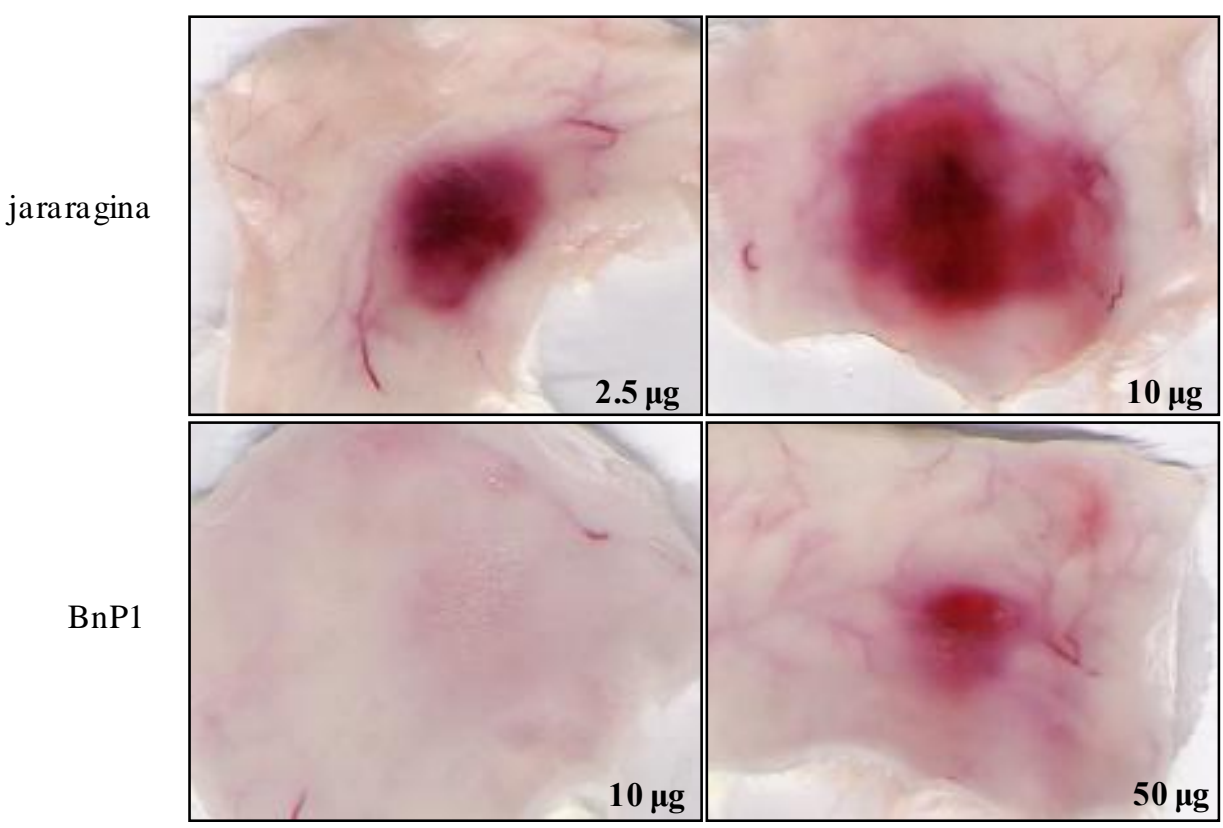

B

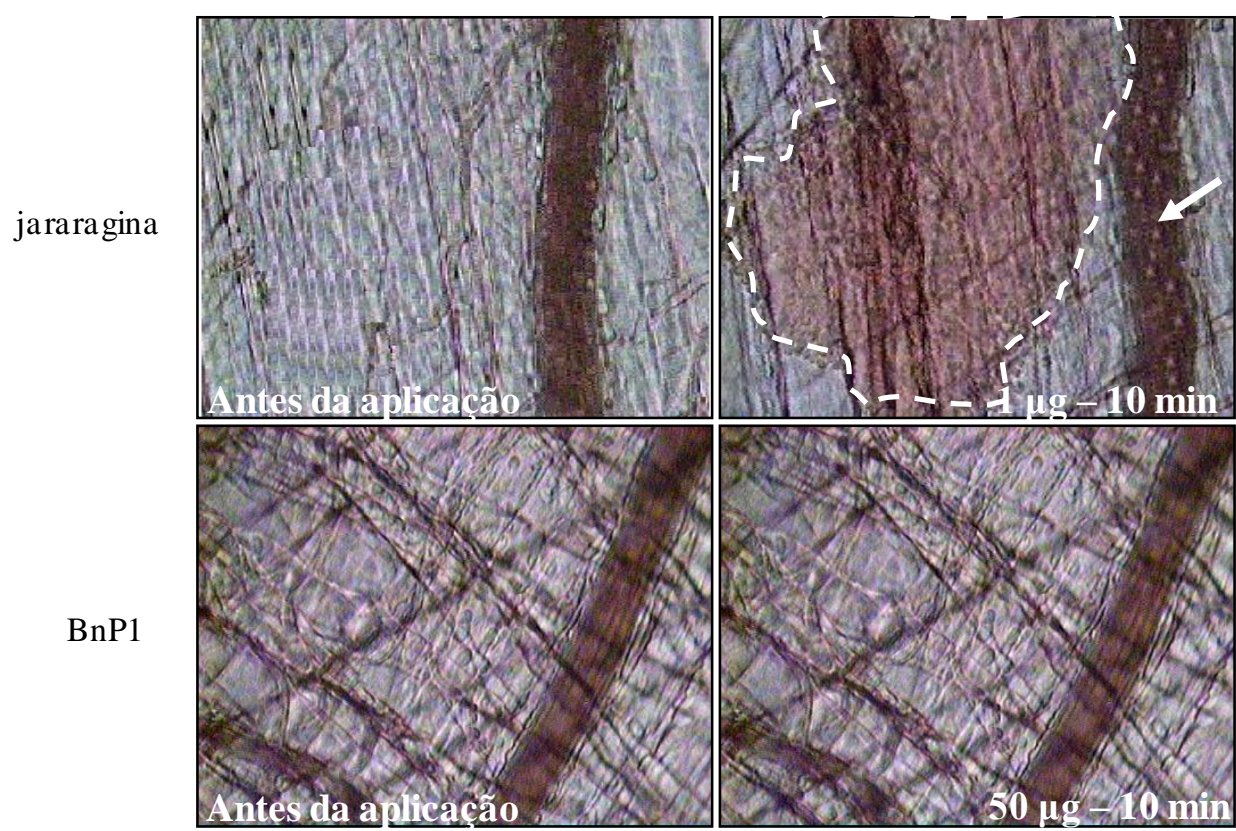

Figura 8-Comparação da atividade hemorrágica da jararagina e BnP1. A- Determinação do halo hemorrágico. Jararagina e $\mathrm{BnP1}$ foram intradermicamente injetadas no dorso de camundongos $\mathrm{BALB} / \mathrm{c}$ e após 3 horas a pele do dorso foi removida para visualização da hemorragia. B- Microscopia intravital do músculo cremaster 10 minutos após a administração tópica da jararagina e $\mathrm{BnP1}$. A região pontilhada mostra a hemorragia induzida pela jararagina e a seta mostra o aumento do rolamento de leucócitos em uma vênula pós-capilar. Os experimentos foram realizados usando grupos de 3 animais e foram repetidos 3 vezes em dias diferentes. Os resultados mostram imagens capturadas em um experimento representativo. 


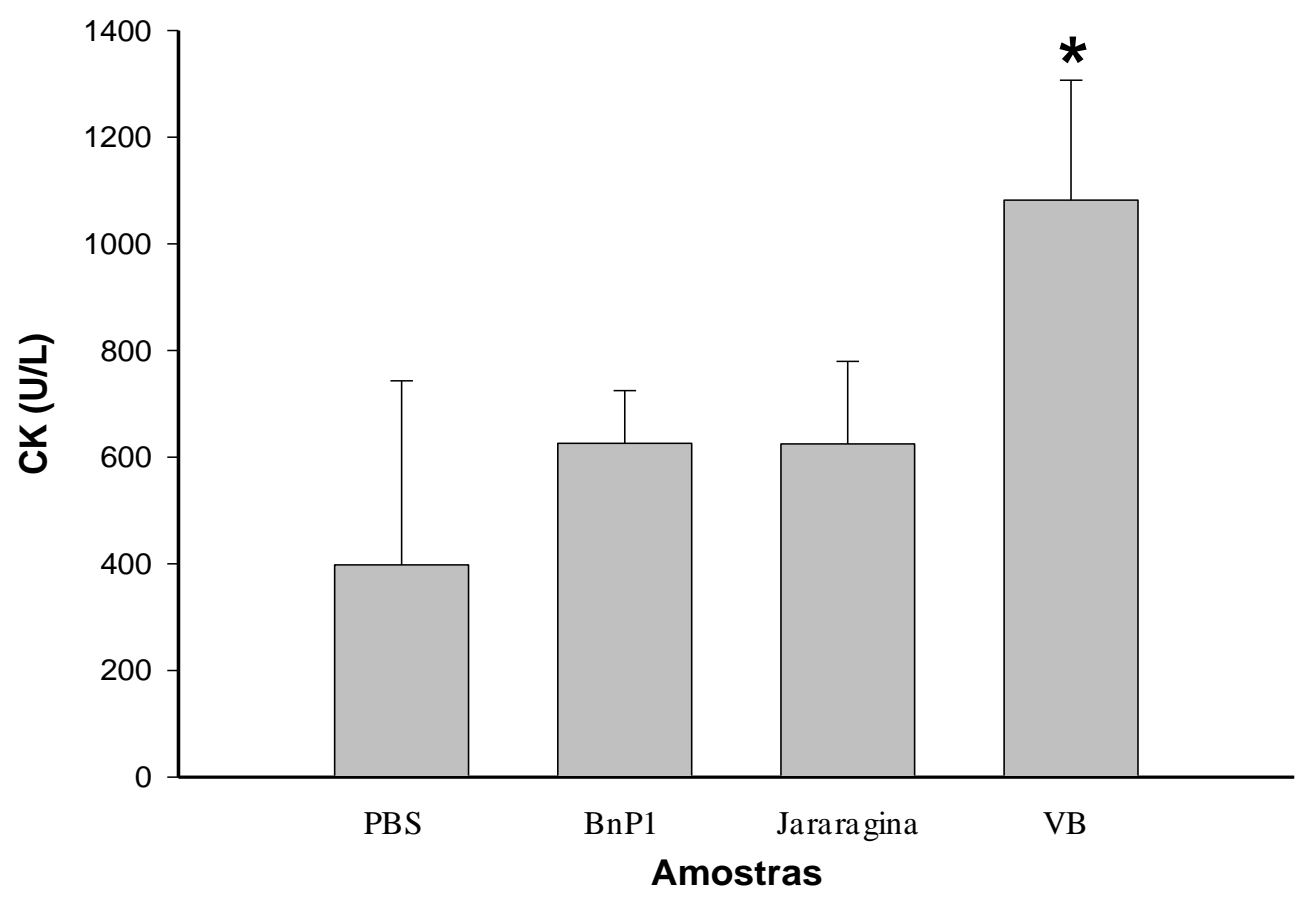

Figura 9- Atividade miotóxica da jararagina e BnP1. Amostras contendo $50 \mu \mathrm{g}$ da jararagina ou BnP1 ou $10 \mu \mathrm{g}$ do veneno de $B$. neuwiedi (VB) foram injetadas no músculo gastrocnêmio de camundongos BALB/c, divididos em grupos de 5 animais. Animais injetados com $50 \mu \mathrm{lde}$ PBS foram utilizados como controle. Após 3 horas, os animais foram sacrificados para a dosagem dos níveis plasmáticos de creatina quinase (CK) usando o kit comercial (Bioclin), conforme instruções do fabricante. Foram realizados 3 experimentos independentes. Os resultados mostram a média e o desvio padrão de um experimento representativo. A análise estatística foi realizada por um teste T-student e o símbolo (*) representa a diferença significativa $(\mathrm{p}<0.05)$ do controle PBS em relação ao veneno de B. neuwiedi.

\subsection{Ação da jararagina e BnP-1 em cultura de células endoteliais}

Nosso próximo passo foi comparar a ação da jararagina e BnP1 em cultura de células endoteliais, buscando identificar razões que justifiquem suas diferenças quanto ao seu potencial hemorrágico. 


\subsubsection{Ensaio de adesão e viabilidade celular}

Inicialmente, a ação da jararagina e BnP1, em razões equimolares, foi comparada quanto à viabilidade e adesão celular, em cultura primária de células endoteliais (HUVECs) e culturas de mioblastos $(\mathrm{C} 2 \mathrm{C} 12)$. As duas toxinas induziram semelhantes efeitos em cultura de HUVECs. Após 6 horas do tratamento de HUVECs com jararagina e BnP1, foi possível verificar o descolamento das células. Após 24 horas, uma drástica diminuição do número de células aderidas foi observada e praticamente nenhuma célula permaneceu aderida às placas de cultura mantidas por 48 horas de tratamento (Figura 10A). A análise da viabilidade celular das culturas de HUVECs tratadas com as diferentes toxinas permitiu verificar a presença de células mortas já às 6 horas, seguida de aumento progressivo da morte celular com o passar do tempo de tratamento (Figura 10B). O efeito das toxinas foi então testado em cultura de células C2C12, onde apenas um descolamento parcial dessas células foi verificado (Figura 10C) e nenhuma significante alteração na viabilidade celular foi observada após o tratamento com a BnP1 e jararagina (Figura 10D). 

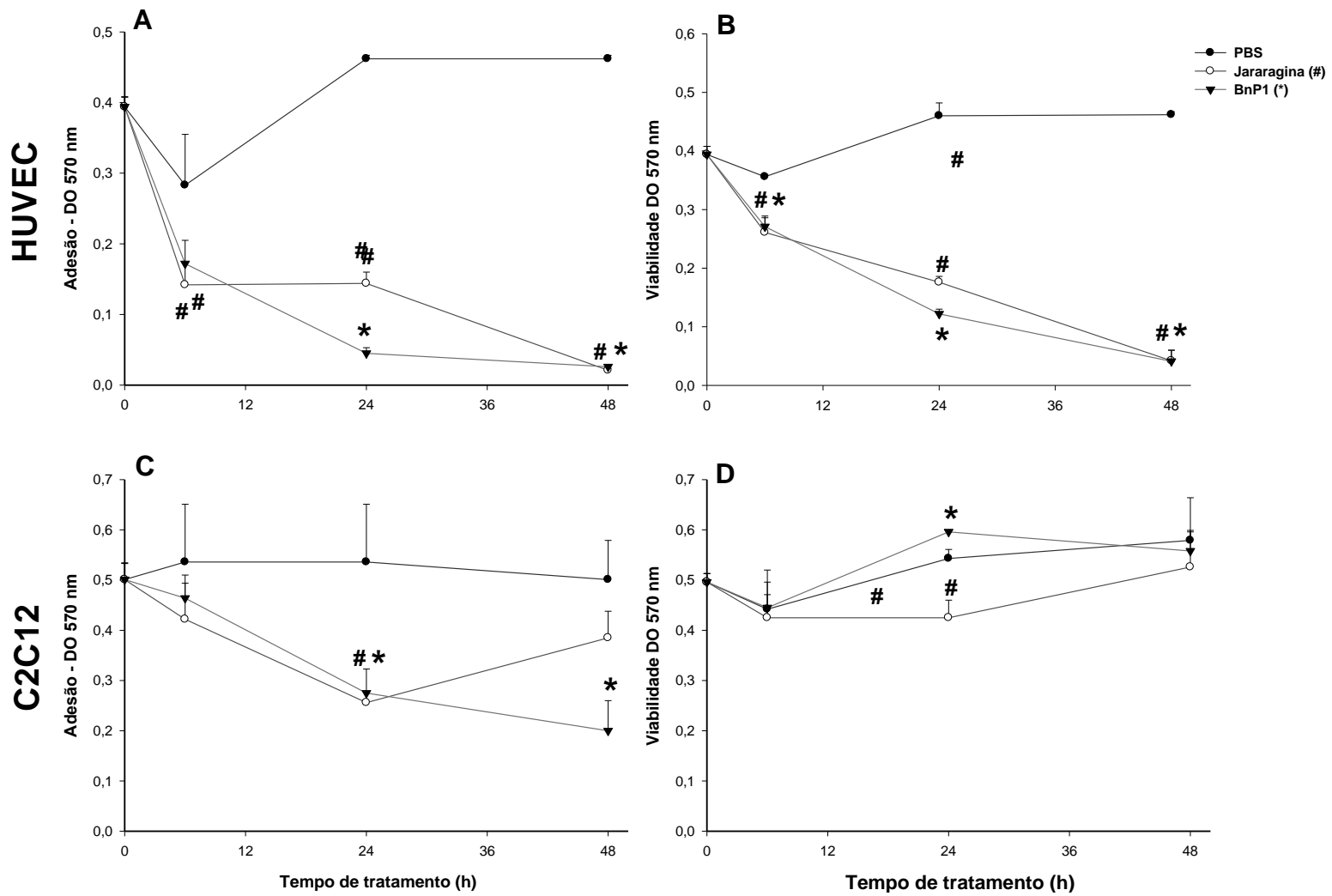

Figura 10-Efeitos da jararagina e $\mathrm{BnP} 1$ na viabilidade e adesão de HUVECs e C2C12. Cultura de HUVECs (A,B) e C2C12 (C,D) foram tratadas com $800 \mathrm{nM}$ de jararagina ou BnP1 por 6, 24 e 48 horas. Após os tempos de tratamento, a adesão (A,C) e a viabilidade celular (B,D) foram determinadas conforme descrito em Materiais e Métodos. Foram realizados 3 experimentos independentes em triplicata. Os resultados mostram a média e o desvio padrão da triplicata de um experimento representativo. A análise estatística foi realizada pelo teste T-student e o símbolo representa a diferença significativa $(\mathrm{p}<0.05)$ da $\mathrm{BnP} 1(*)$ ou jararagina (\#) em relação ao controle PBS.

\subsubsection{Apoptose e citotoxicidade}

Os mecanismos envolvidos na redução da viabilidade celular induzida pela jararagina e BnP1 foram avaliados através da análise da fragmentação do DNA e dosagem da atividade da enzima lactato desidrogenase $(\mathrm{LDH})$. Jararagina e $\mathrm{BnP} 1$, na mesma razão molar, não induziram apoptose de HUVECs após 6 horas de tratamento. Um discreto aumento na taxa de apoptose foi notado após 24 horas (12.5\% para a jararagina e $11.4 \%$ para a $\mathrm{BnP} 1)$, seguido 
por significante aumento na taxa de apoptose observado após 48 horas do tratamento com jararagina (50\%) e $\mathrm{BnP} 1$ (76\%), como mostrado na figura 11A. As células C2C12, submetidas ao mesmo tratamento, não sofreram apoptose em nenhum dos tempos analisados (Figura 11C). Por outro lado, apenas um pequeno aumento na concentração de LDH foi observado no tempo de 48 horas para ambas culturas (Figura 11B e 11D). Esses dados sugerem que a queda da viabilidade de células endoteliais, desencadeada tanto pela jararagina quanto pela $\mathrm{BnP} 1$, ocorre predominantemente por apoptose e que a necrose desempenha papel secundário na redução da viabilidade de HUVECs. Este efeito parece ser seletivo para células endoteliais, uma vez que cultura de miotúbulos mostraram-se resistentes ao tratamento com ambas toxinas.
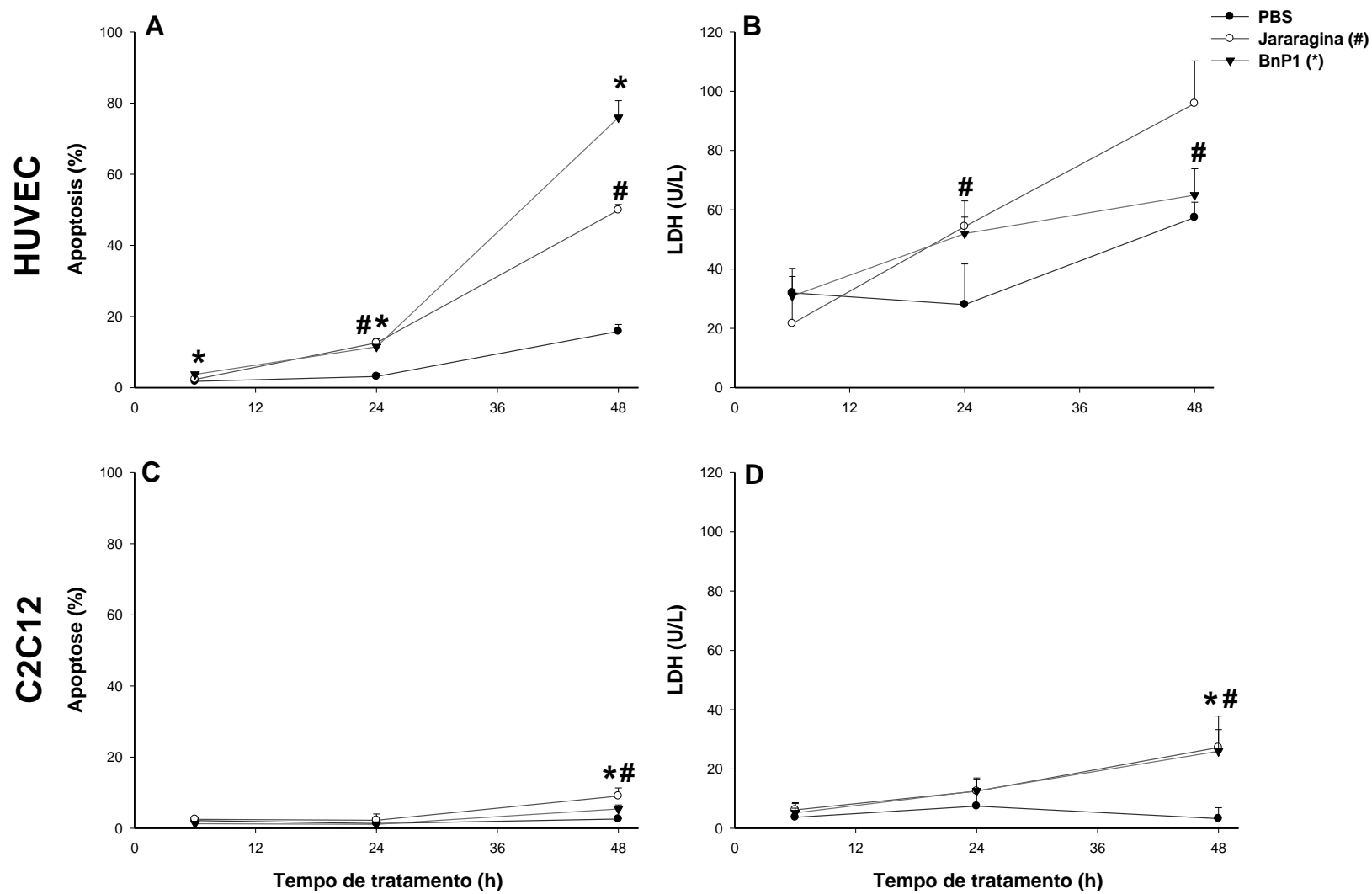

Figura 11- Apoptose e citotoxicidade induzidas pela jararagina e BnP1 em culltura de HUVECs e C2C12. Cultura de HUVECs $(\mathbf{A}, \mathbf{B})$ e C2C12 (C,D) foram tratadas com $800 \mathrm{nM}$ de jararagina ou BnP1 por 6, 24 e 48 horas. Após os tempos de tratamento, a apoptose (A,C) e a citotoxicidade (B,D) foram determinadas conforme descrito em Materiais e Métodos. Foram realizados 3 experimentos independentes em triplicata. Os resultados mostram a média e o desvio padrão da triplicata de um experimento representativo. A análise estatística foi realizada pelo teste T-student e o símbolo representa a diferença significativa $(\mathrm{p}<0.05)$ da $\mathrm{BnP1}(*)$ ou jararagina (\#) em relação ao controle PBS. 


\subsubsection{Ação no citoesqueleto}

$\mathrm{O}$ efeito da jararagina e $\mathrm{BnP} 1$ sobre a polimerização dos filamentos de actina em HUVECs foi avaliado através de ensaio de imunofluorescência usando a faloidina conjugada com a rodamina. A figura 12A mostra as células controle espraiadas, com típicas longas fibras de actina polimerizada que percorrem todo o compartimento celular (fibras de estresse). Entretanto, 10 minutos após o tratamento das células com a jararagina, observou-se uma grande mudança morfológica com redução drástica no espraiamento celular. Foi possível observar a perda das fibras de estresse e o acúmulo da actina na região cortical da célula. As alterações induzidas pela $\mathrm{BnP} 1$ no citoesqueleto de actina foram aparentemente menos drásticas do que as alterações induzidas pela jararagina. A ação da jararagina e BnP1 na rede de microtúbulos de HUVECs também foi avaliada. Na figura 12B observa-se que as células tratadas somente com PBS apresentaram a rede de microtúbulos regularmente distribuída por todo o compartimento celular. Após 10 minutos do tratamento das células com jararagina e $\mathrm{BnP} 1$, verificou-se uma evidente mudança da morfologia da célula, assim como foi observado para a marcação do citoesqueleto de F-actina. O efeito das toxinas no citoesqueleto foi totalmente abolido quando as toxinas foram inativadas com EDTA (Figura 13). 


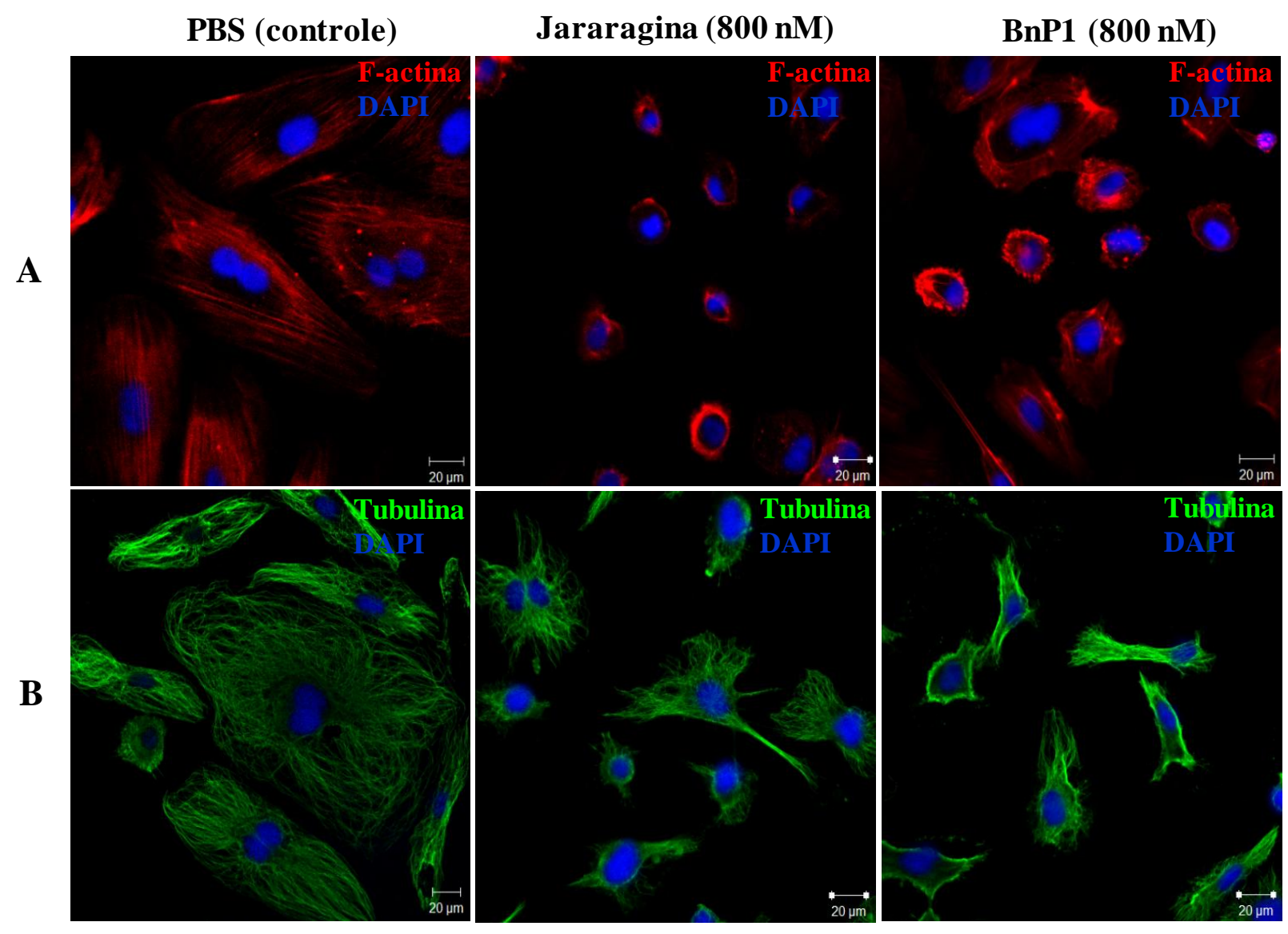

Figura 12- Efeito da jararagina e BnP1 no citoesqueleto de HUVECs. As células foram tratadas com $800 \mathrm{nM}$ de jararagina ou BnP1 por 10 minutos. Os filamentos de actina (A) foram marcados com faloidina conjugada com rodamina (1:100) e os microtúbulos (B) foram marcados com anticorpo anti-tubulina (1:100) e revelados com o anticorpo secundário específico conjugado com Alexa fluor 488 (1:1000). A coloração do núcleo foi realizada com DAPI. O material foi analisado num microscópio confocal (LSM-510-Meta, Zeiss). 
PBS + EDTA
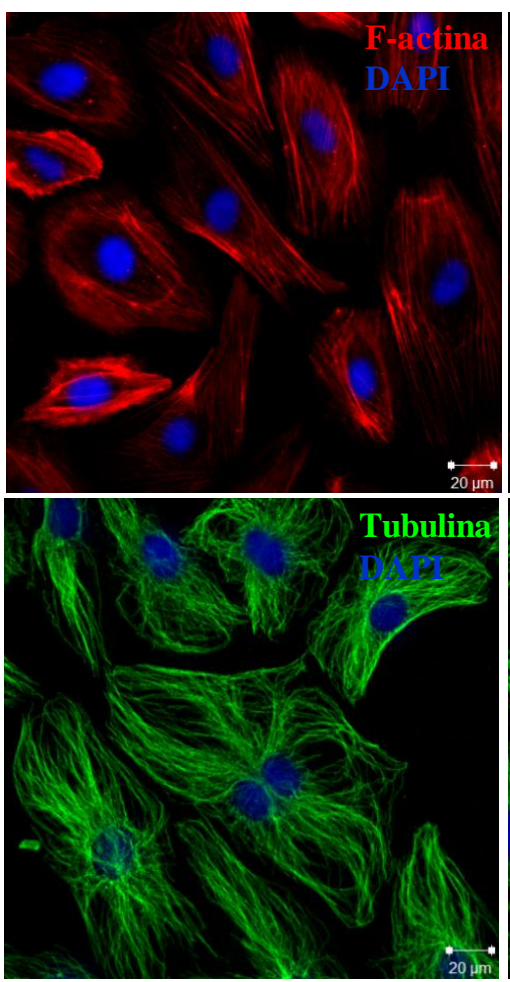

Jararagina + EDTA
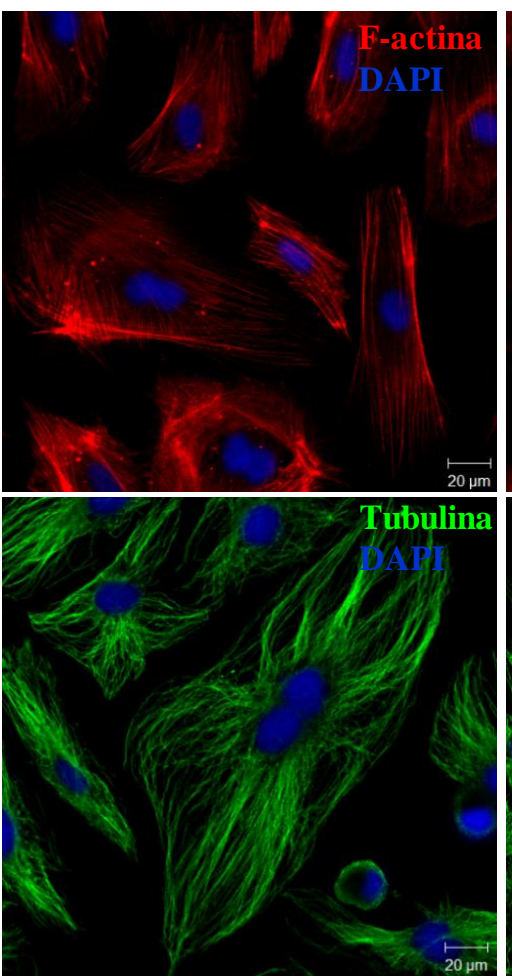

BnP1 + EDTA

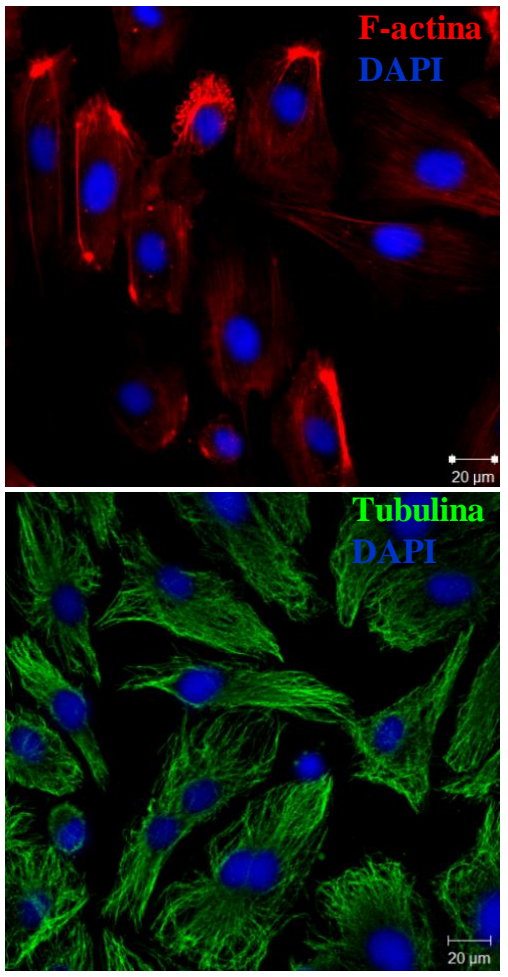

Figura 13- Ação da jararagina e BnP1 cataliticamente inativadas no citoesqueleto de HUVECs. As células foram estimuladas com $800 \mathrm{nM}$ de jararagina ou BnP1, tratadas com EDTA, por 10 minutos. Os filamentos de actina foram marcados com faloidina conjugada com rodamina (1:100) e os microtúbulos foram marcados com anticorpo anti-tubulina (1:100) e revelados com o anticorpo secundário específicos conjugado com Alexa fluor 488 (1:1000). A coloração do núcleo foi realizada com DAPI. O material foi analisado num microscópio confocal (LSM-510-Meta, Zeiss). 


\subsection{Ação das SVMPs em proteínas plasmáticas e de matriz extracelular}

Considerando o efeito semelhante da jararagina e BnP1 em células endoteliais, nosso próximo passo foi comparar seus efeitos em proteínas plasmáticas e de matriz extracelular, avaliando dois diferentes aspectos: hidrólise e adesividade.

\subsubsection{Hidrólise dos componentes plasmáticos e de matriz extracelular}

A atividade fibrinolítica das toxinas foi testada em placas de fibrina-agarose. Este ensaio mostrou que a jararagina e BnP1 foram capazes de degradar a fibrina de maneira dosedependente. No entanto, a jararagina mostrou atividade fibrinolítica maior que a BnP1 (Figura 14). A atividade proteolítica sobre o fibrinogênio também foi testada e mostrou que as duas toxinas foram capazes de clivar as cadeias $\mathrm{A} \alpha$ e $\mathrm{B} \beta$ da molécula de fibrinogênio (Figura 15). No entanto, a jararagina clivou o fibrinogênio em tempos menores que a BnP1. Após 15 minutos de incubação com a jararagina, observou-se o total desaparecimento da cadeia $\alpha$, enquanto que nas amostras incubadas com a BnP1 este mesmo efeito foi somente observado após 1 hora. A hidrólise da cadeia $\beta$ pela jararagina também foi mais rápida que nas amostras incubadas com a BnP1. A hidrólise da cadeia $\gamma$ não foi observada. Quando as toxinas foram incubadas com $10 \mathrm{mM}$ de EDTA, a atividade fibrinogenolítica foi totalmente abolida (Figura 16, linha 7). Por outro lado, observamos que a jararagina e BnP1 não foram capazes de clivar a laminina em nenhum dos tempos de incubação analisados (Figura 16).

Considerando a semelhança de capacidade hidrolítica de componentes plasmáticos e de matriz extracelular das duas classes de toxinas, concluímos que a atividade catalítica, independentemente, não explica a diferença de potencial hemorrágico observado entre a jararagina e BnP1. 


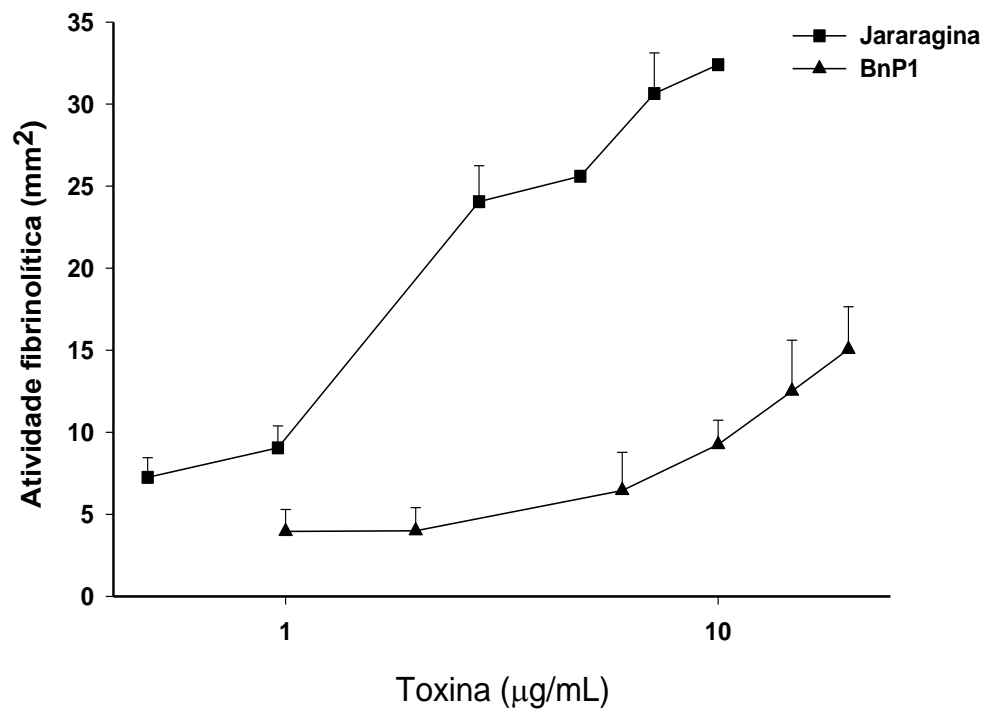

Figura 14- Comparação da atividade fibrinolítica da jararagina e $\mathrm{BnP} 1$ em placa de fibrina-agarose. A atividade fibrinolítica foi realizada com diferentes concentrações das toxinas e avaliada pelo diâmetro $\left(\mathrm{mm}^{2}\right)$ do halo de lise, após 18 horas de incubação. Foram realizados 3 experimentos independentes em triplicata. Os resultados mostram a média e o desvio padrão da triplicata de um experimento representativo.

Jararagina $\quad$ BnP1

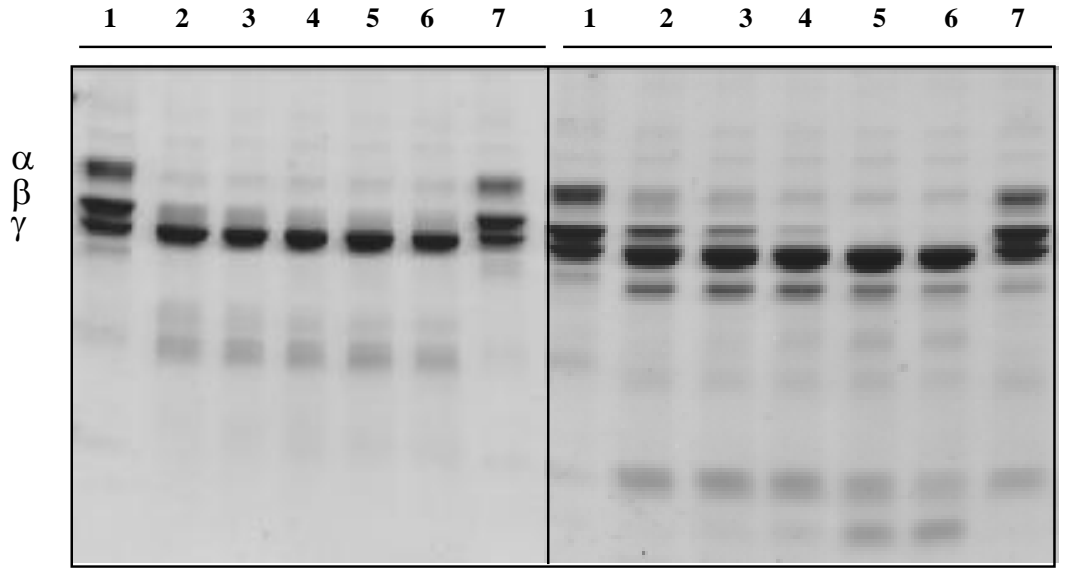

Figura 15- Perfil de degradação do fibrinogênio humano pela jararagina e BnP1. Amostras contendo $20 \mu \mathrm{g}$ de fibrinogênio (1) foram incubadas com $1 \mu \mathrm{g}$ de jararagina ou BnP1 em diferentes intervalos de tempo (2: $15 \mathrm{~min} ; 3: 30 \mathrm{~min} ; 4: 1 \mathrm{~h} ; 5: 3 \mathrm{~h} ; 6: 6 \mathrm{~h})$. A atividade fibrinogenolítica das toxinas inativadas com EDTA está mostrada na linha 7. O perfil de degradação do fibrinogênio foi visualizado em SDS-PAGE 12,5\% em condições redutoras. Os géis foram corados com Coomassie brilliant blue. 


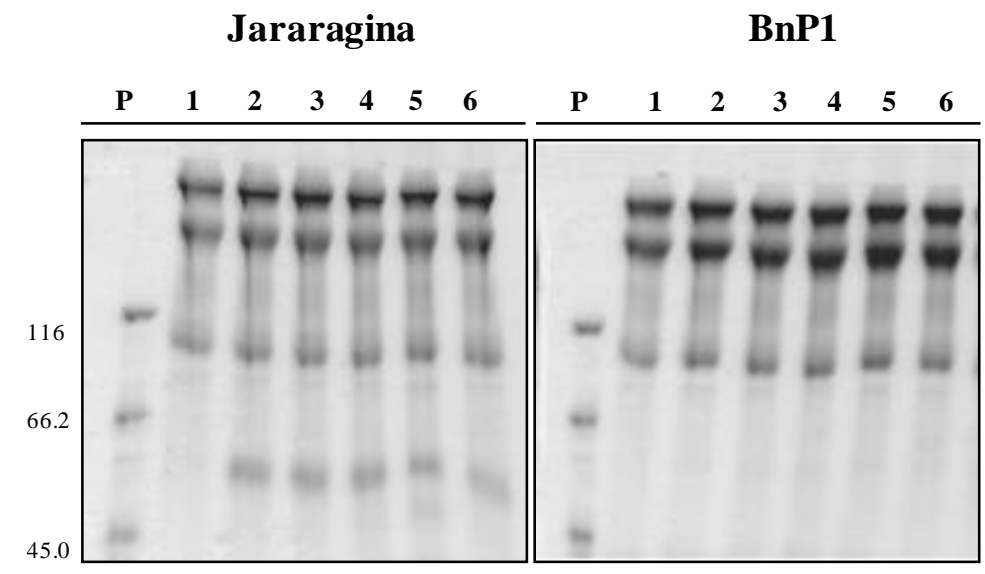

Figura 16- Perfil de degradação da lamina pela jararagina e BnP1. Amostras contendo $10 \mu \mathrm{g}$ de laminina (1) foram incubadas com $1 \mu \mathrm{g}$ de jararagina ou $\mathrm{BnP} 1 \mathrm{em}$ diferentes intervalos de tempo (2: $30 \mathrm{~min} ; \mathbf{3 :}$ 1h; 4: $3 \mathrm{~h} ; \mathbf{5}: 6 \mathrm{~h}$ ). A ação proteolítica das toxinas inativadas com EDTA está mostrada na linha 6 . O perfil de degradação da laminina foi visualizado em SDS-PAGE 7,5\% em condições redutoras. Os géis foram corados com Coomassie brilliant blue. P: padrão de massa molecular.

\subsubsection{Capacidade de ligação das SVMPs à proteínas plasmáticas e de matriz extracelular}

Uma vez que não foram observadas diferenças qualitativas quanto a ação catalítica da jararagina e $\mathrm{BnP} 1$, seguimos o nosso estudo com a avaliação da ligação a proteínas plasmáticas e de matriz extracelular no sentido de correlacionar esses eventos com o desencadeamento da atividade hemorrágica. A afinidade da jararagina ao colágeno tipo I, anteriormente descrita por Tanjoni et al. (2003), foi comparada com sua capacidade de interação com outras proteínas de matriz extracelular e proteínas plasmáticas, assim como com a afinidade da $\mathrm{BnP} 1$ e jararagina-C por essas proteínas.

De acordo com a figura 17, a jararagina foi capaz de se ligar, com alta afinidade ao colágeno I e IV, sendo a reação detectável até a concentração de $0,018 \mathrm{nM}$. Por outro lado, a ligação da BnP1 não foi observada mesmo quando altas concentrações foram utilizadas (80 $\mathrm{nM})$. A jararagina-C também foi capaz de se ligar ao colágeno I e IV, até a concentração de 0,05 nM, mas com afinidade menor em relação à jararagina. Uma fraca interação da jararagina e jararagina-C à laminina foi observada, mas somente em altas doses. A interação da BnP1 à laminina não foi verificada. A ligação ao fibrinogênio não foi detectada para nenhuma das três SVMPs. 

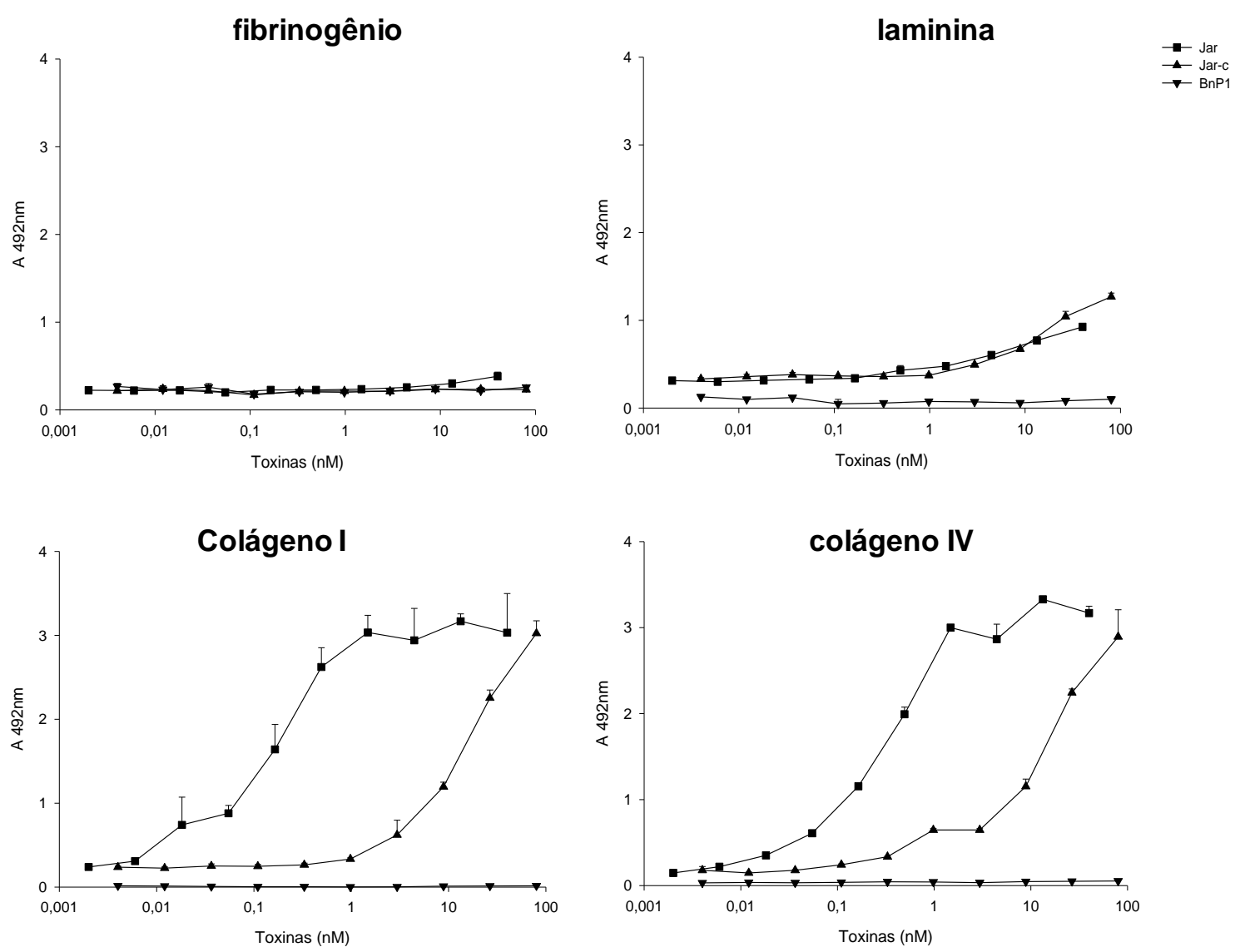

Figura 17- Interação das SVMPs à componentes plasmáticos e de matriz extracelular. Diferentes concentrações das toxinas foram incubadas com fibrinogênio, colágeno I, colágeno IV ou laminina $(10 \mu \mathrm{g} / \mathrm{mL})$ imobilizados em microplacas. A ligação foi avaliada por ELISA, utilizando IgG de coelho anti-jararagina para a jararagina (jar) e jararagina-C (jar-C) ou $\mathrm{IgG}$ de coelho anti-neuwiedase (1:100) para a BnP1. Como anticorpo secundário específico foi utilizado soro anti-IgG de coelho marcado com a peroxidase (1:2000), seguida da incubação com o substrato cromógeno OPD. A intensidade da coloração foi lida a $492 \mathrm{~nm}$. Foram realizados 3 experimentos independentes em triplicata. Os resultados mostram a média e o desvio padrão da triplicata de um experimento representativo. 


\subsubsection{Região estrutural envolvida na ligação da jararagina ao colágeno}

Com o objetivo de avaliar a região do colágeno envolvida na interação com a jararagina, ensaios utilizando fragmentos recombinantes do colágeno tipo I (FC0 e FC3) também foram realizados. A figura 18 mostra que a jararagina foi capaz de se ligar ao colágeno tipo I e aos fragmentos FC0 (tripla hélice) e FC3 (tripla hélice contendo o sítio de ligação da integrina $\alpha_{2} \beta_{1}$ ) praticamente com a mesma afinidade. Além disso, observamos que a ligação da jararagina ao colágeno I foi significativamente reduzida quando a molécula de colágeno I foi desnaturada (Figura 19). Esses dados sugerem que a interação da jararagina ao colágeno é dependente da estrutura em tripla hélice da molécula, mas ocorre independentemente do sítio de ligação da integrina $\alpha_{2} \beta_{1}$

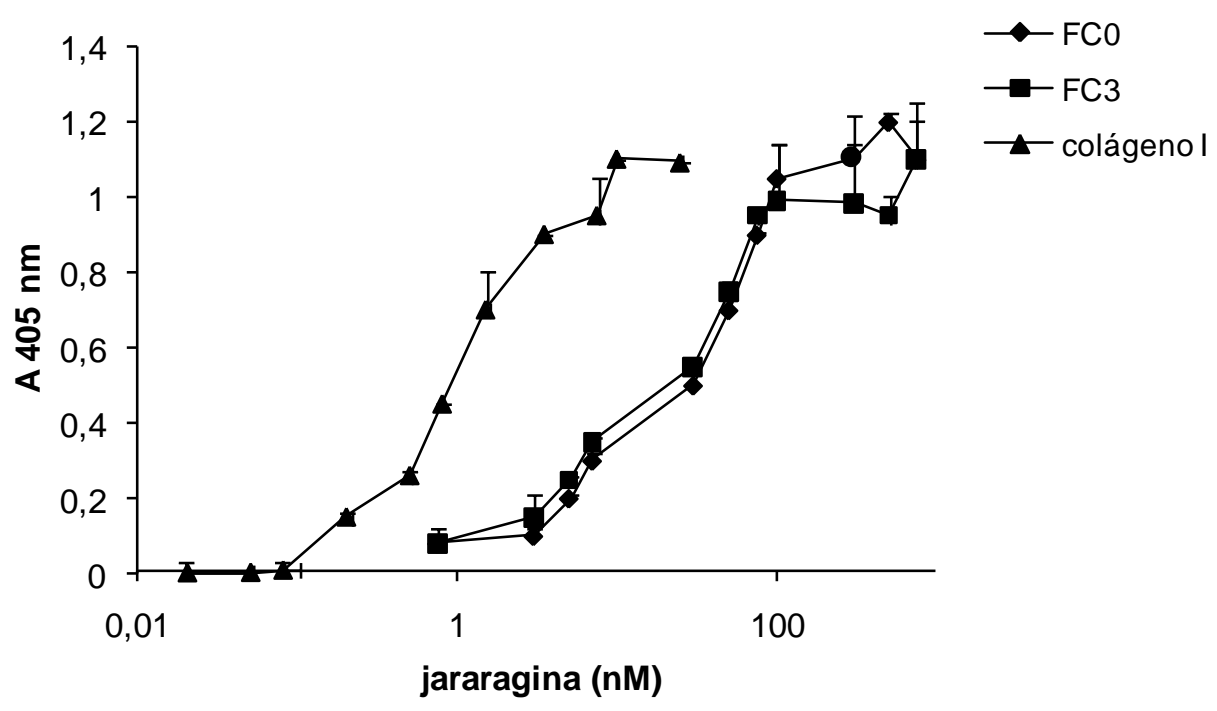

Figura 18- Região estrutural envolvida na ligação da jararagina ao colágeno. Diferentes concentrações da jararagina foram incubadas com colágeno I ou com os fragmentos recombinantes do colágeno contendo a região da tripla-hélice genérica (FCO) ou com a inclusão do sítio de ligação à integrina $\alpha 2 \beta 1$ (FC3) na concentração de $8 \mu \mathrm{g} / \mathrm{mL}$, previamente imobilizados em microplacas. A ligação foi avaliada por ELISA, utilizando IgG de coelho anti-jararagina $(1: 100)$ e o anticorpo secundário conjugado com fosfatase alcalina (1:2000). O complexo antígeno/anticorpo foi revelado com uma solução de NBT/BCIP. A leitura foi feita em 405 $\mathrm{nm}$ em um leitor de ELISA. Foram realizados 3 experimentos independentes em triplicata. Os resultados mostram a média e o desvio padrão da triplicata de um experimento representativo. 


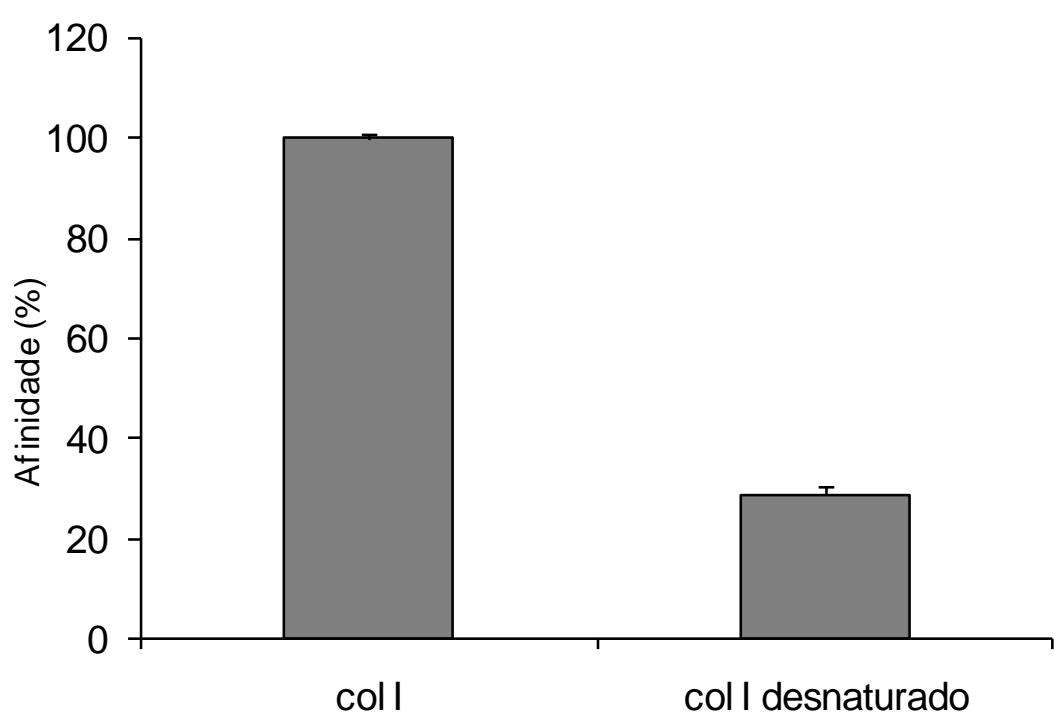

Figura 19- Interação da jararagina com o colágeno I desnaturado. A jararagina foi incubada com o colágeno I ou colágeno I desnaturado $(5 \mu \mathrm{g} / \mathrm{mL})$. A ligação foi avaliada por ELISA, utilizando $\operatorname{IgG}$ de coelho anti-jararagina (1:100) e o anticorpo secundário conjugado com fosfatase alcalina (1:2000). O complexo antígeno/anticorpo foi revelado com uma solução de NBT/BCIP. A leitura foi feita em $405 \mathrm{~nm}$ em um leitor de ELISA. Foram realizados 3 experimentos independentes em triplicata. Os resultados mostram a média e o desvio padrão da triplicata de um experimento representativo.

\subsubsection{Atividades biológicas da jararagina complexada com o colágeno}

Considerando-se que a alta afinidade da jararagina ao colágeno pode ser um fator importante para a indução da hemorragia, investigamos se esta ligação interfere na expressão da atividade hemorrágica desta toxina. Nesses experimentos, observamos que o complexo jararagina/colágeno I obtido in vitro inibiu parcialmente a hemorragia na proporção 1:10, apresentando $100 \%$ de inibição quando a proporção de 1:20 foi usada. Para o colágeno IV, a atividade hemorrágica foi totalmente inibida na proporção de 1:10 (Figura 20). A atividade fibrinolítica da jararagina complexada ao colágeno I também foi testada, e verificamos que esta ligação não alterou, de maneira significativa, a atividade fibrinolítica desta toxina (Figura 21). Esses dados sugerem que a ligação ao colágeno bloqueia sítios importantes para a indução da hemorragia, mas não interfere em sua atividade catalítica deixando o sítio catalítico exposto para catálise. 


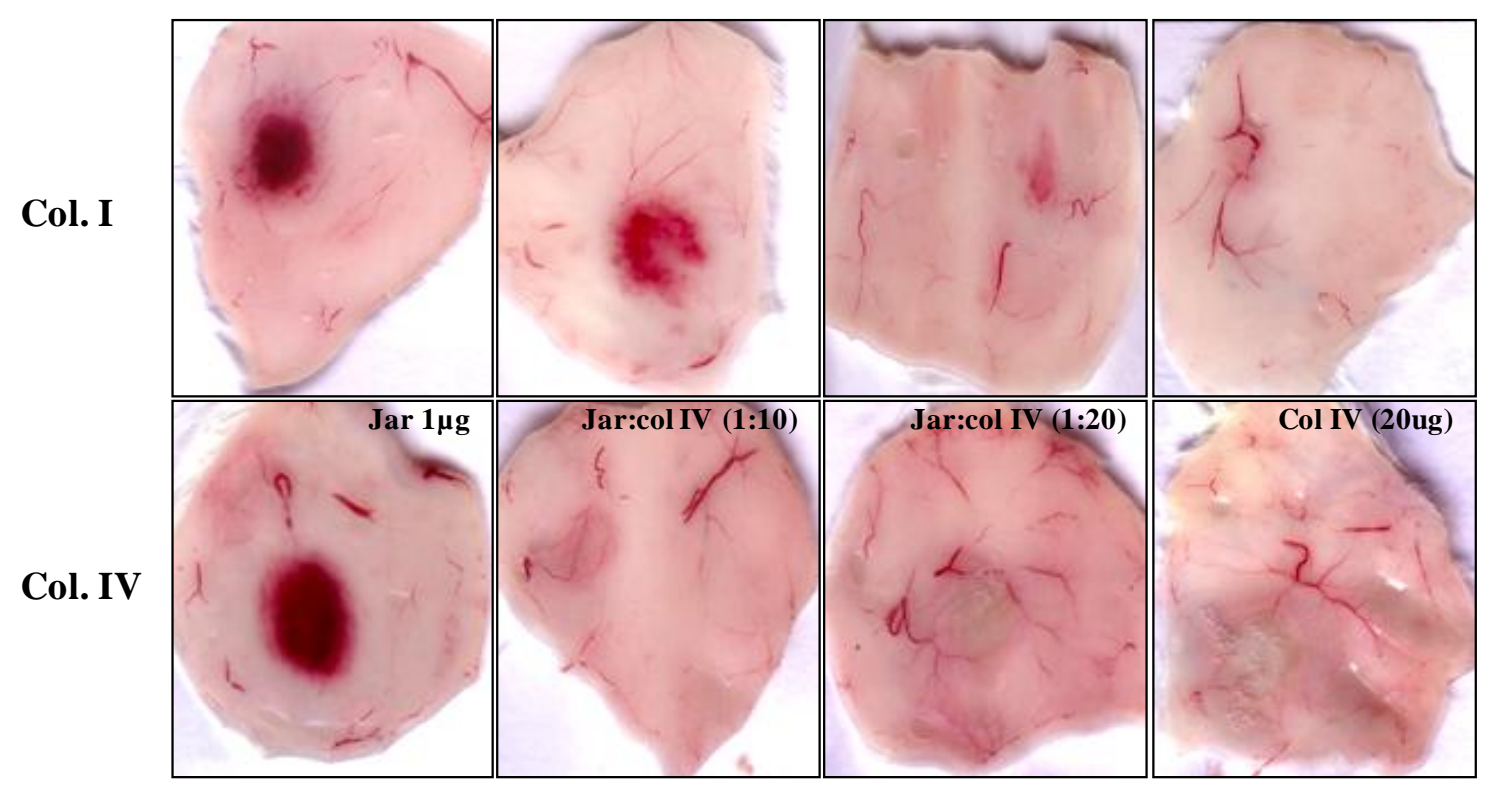

Figura 20- Atividade hemorrágica da jararagina complexada ao colágeno. A jararagina $(1 \mu \mathrm{g})$ foi incubada com diferentes concentrações de colágeno tipo I e IV, por 30 minutos a $37^{\circ} \mathrm{C}$. A ação hemorrágica foi avaliada após 15 minutos da injeção intradérmica das amostras na pele do dorso de camundongos BALB/c. 


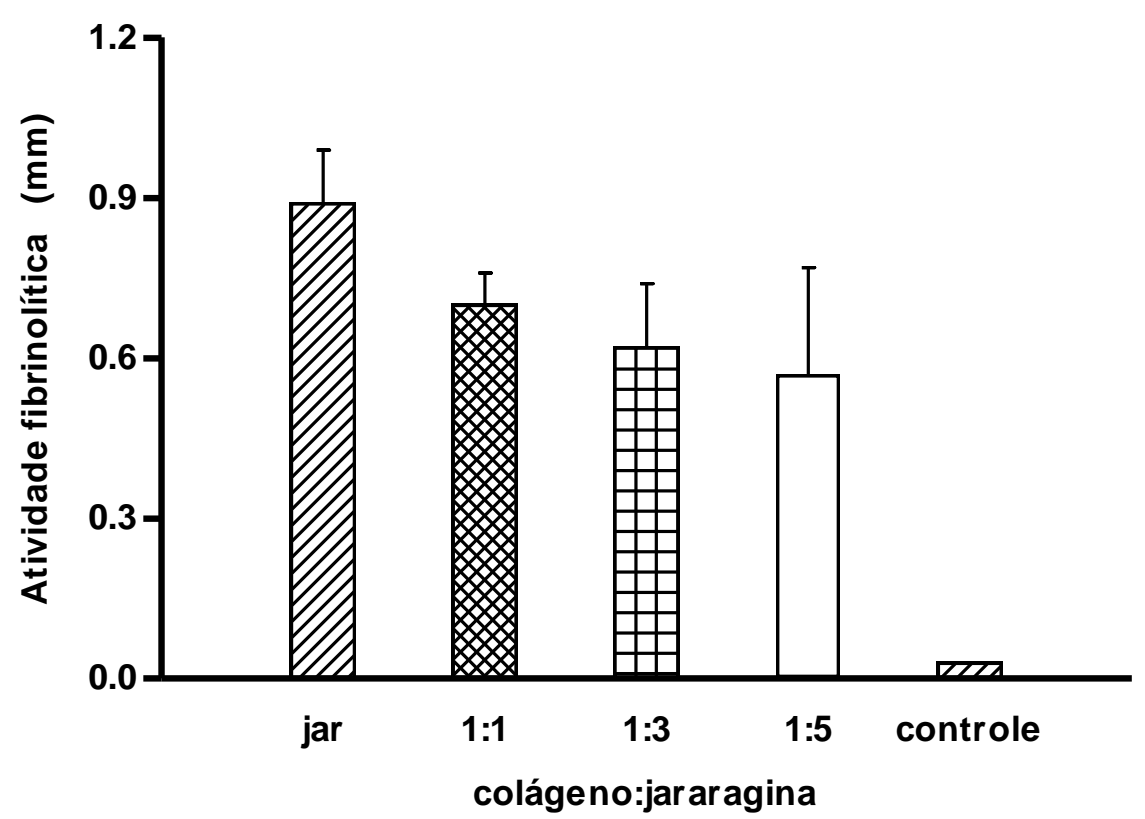

Figura 21- Atividade fibrinolítica da jararagina complexada ao colágeno. A jararagina (10 $\mu \mathrm{g})$ foi incubada com concentrações crescentes de colágeno tipo I, por 30 minutos a $37^{\circ} \mathrm{C}$. As amostras foram testadas quanto a atividade fibrinolítica, utilizando-se placas de fibrinaagarose. Foram realizados 3 experimentos independentes em triplicata. Os resultados mostram a média e o desvio padrão da triplicata de um experimento representativo.

\subsection{Ação da BnP1 e jararagina na pele do dorso de camundongos}

Os experimentos anteriores mostraram diferenças no comportamento das SVMPs quanto à afinidade a proteínas da matriz extracelular, especialmente o colágeno. Nosso próximo passo foi avaliar num sistema ex vivo a capacidade de ligação aos componentes de matriz extracelular, biodistribuição e as alterações patológicas induzidas pelas SVMPs, utilizando a pele como modelo experimental. 


\subsubsection{Análise histológica}

As alterações na pele do dorso de camundongos foram primeiramente avaliadas 1 hora após a injeção de doses equimolares de jararagina e BnP1. Os animais injetados com a jararagina mostraram intensa hemorragia enquanto que a ausência de hemorragia foi característica nos animais injetados com a BnP1. Lesões hemorrágicas induzidas pela BnP1 ocorreram apenas com uma dose de $50 \mu \mathrm{g}$ (Figura 22A). A análise histológica desse material revelou um evidente aumento da espessura da pele nas amostras injetadas com jararagina (10 $\mu \mathrm{g})$ e BnP1 (5 e $50 \mu \mathrm{g}$ ), em comparação com o controle PBS, refletindo a ação de ambas as toxinas no desenvolvimento do edema. Entretanto, uma provável degradação do colágeno fibrilar na região da hipoderme foi observada apenas nas amostras com lesões hemorrágicas, injetadas com jararagina ou BnP1 (50 $\mu \mathrm{g})$ (Figura 22B).

Uma nova análise histológica foi realizada após 15 minutos da injeção de doses equimolares de jararagina e BnP1. O grupo controle apresentou a pele com aspecto normal, com a epiderme e derme preservadas (Figura 23ABC). No entanto, um drástico processo hemorrágico evidenciado pelo grande número de hemácias foi observado após a injeção da jararagina, principalmente na região correspondente a hipoderme (Figura 23E). Além disso, a jararagina induziu evidentes alterações na camada de tecido muscular localizada abaixo da hipoderme (Figura 23F), região onde o principal foco hemorrágico foi verificado. No entanto, alterações na epiderme e membrana basal vascular não foram observadas (Figura 23D). A injeção da BnP1 não induziu alterações morfológicas (Figura 23GHI), apresentando-se muito semelhante ao controle PBS. Apenas alguns pontos hemorrágicos na região da hipoderme foram verificados quando a dose de $50 \mu \mathrm{g}$ de $\mathrm{BnP} 1$ foram injetados (Figura 23M). 


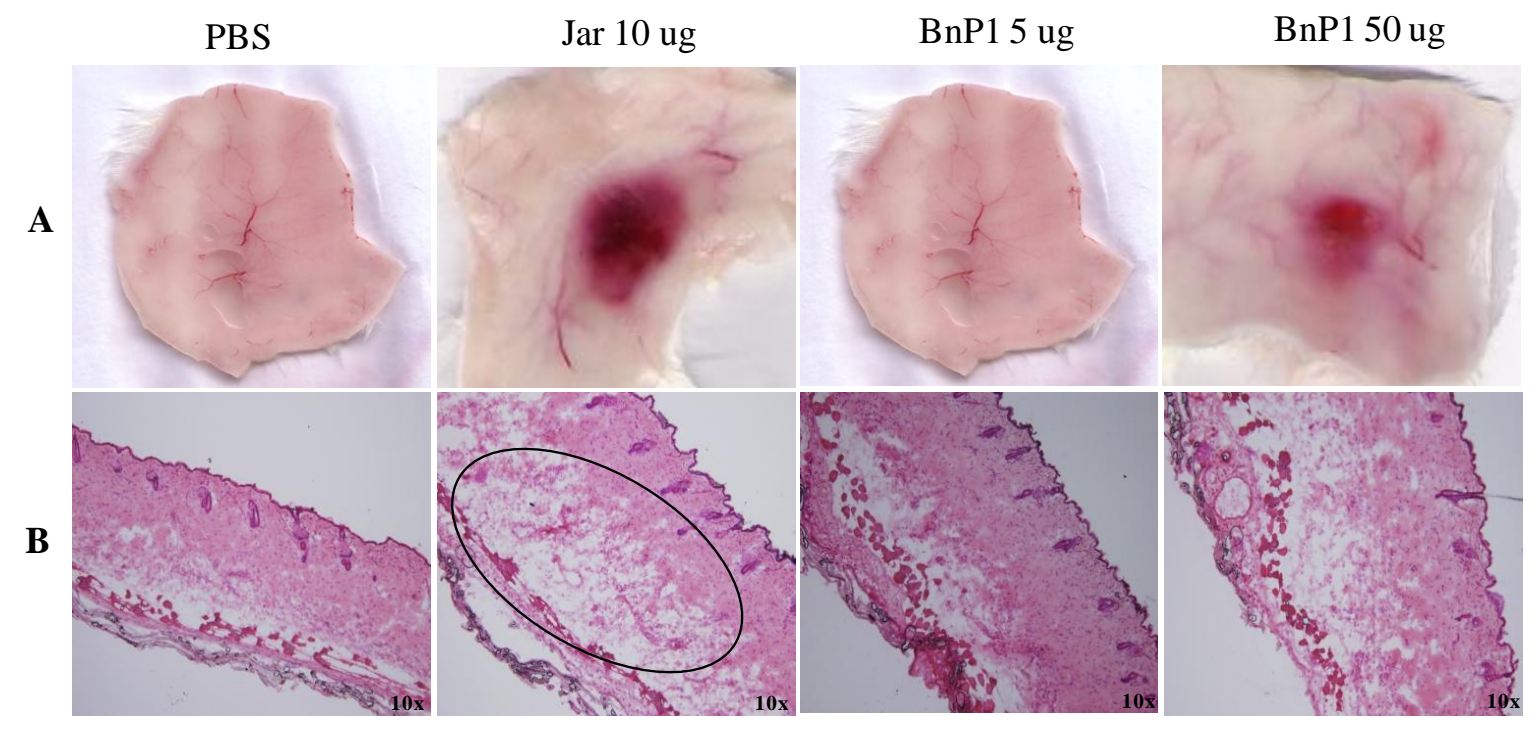

Figura 22- Ação da jararagina e BnP1 na pele do dorso de camundongos. Doses equimolares de jararagina e $\mathrm{BnP} 1$ ou uma dose hemorrágica de $\mathrm{BnP} 1(50 \mu \mathrm{g})$ foram injetadas intradermicamente no dorso de camundongos que foram sacrificados após 1 hora. Animais injetados com PBS foram usados como controle. A- Visão macroscópica da pele após injeção das toxinas. B- Análise histológica da lesão hemorrágica induzida pelas toxinas. As amostras injetadas com PBS mostram a pele com aspecto normal, com a epiderme e derme preservadas. Amostras injetadas com jararagina apresentaram um aumento da espessura da pele e uma evidente degradação na região da hipoderme (círculo). A injeção de $5 \mu \mathrm{g}$ de $\mathrm{BnP1}$ resultou apenas no aumento da espessura da pele em relação ao PBS, enquanto que as amostras injetadas com $50 \mu \mathrm{g}$ de $\mathrm{BnP1}$ apresentaram alterações morfológicas semelhantes às descritas para as amostras injetadas com a jararagina. Coloração: hematoxilina-eosina. 

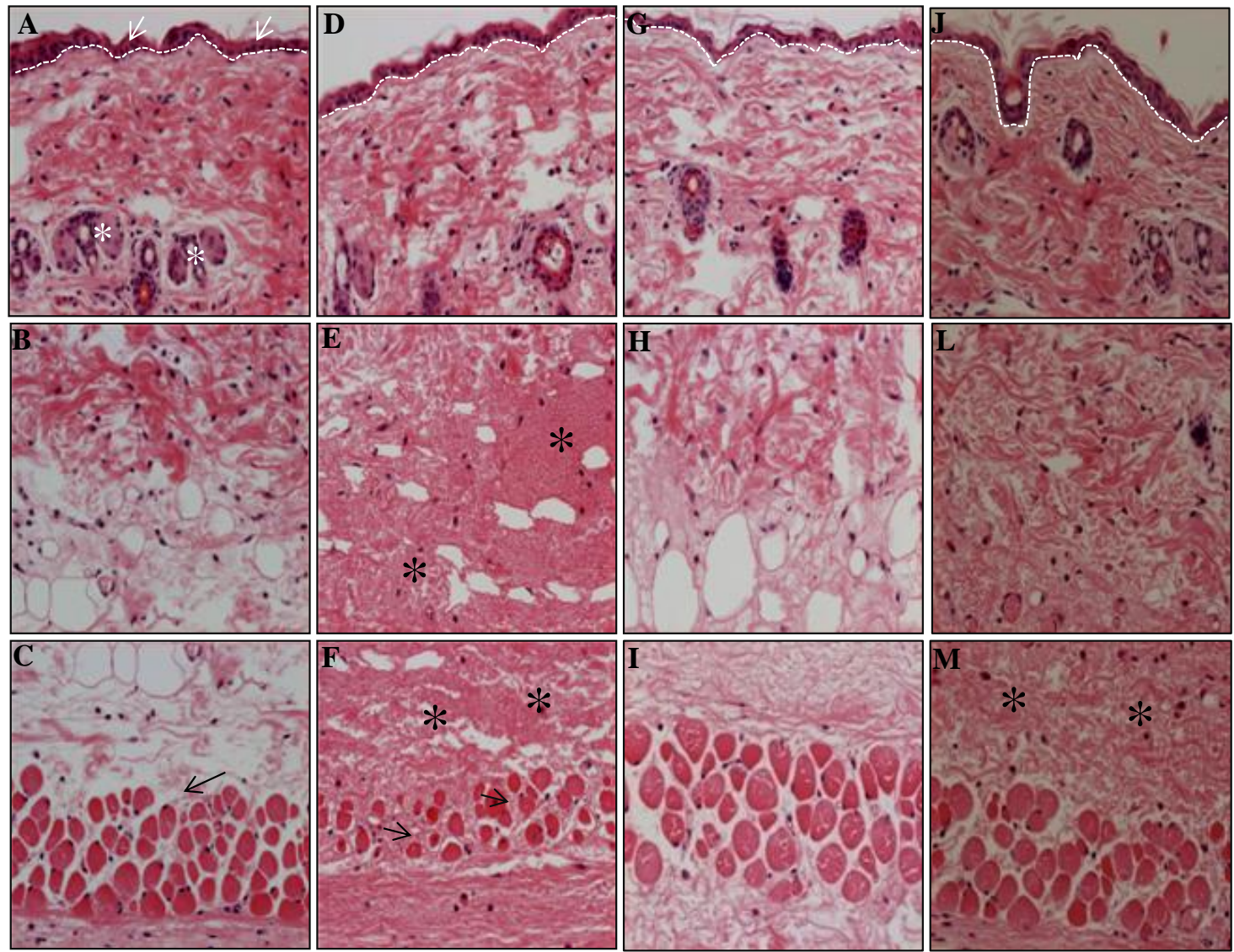

Figura 23- Análise histológica de cortes de $5 \mu \mathrm{m}$ da pele do dorso de camundongos BALB/c após 15 minutos da injeção intradérmica de jararagina $(10 \mu \mathrm{g})$ e BnP1 $(5 \mu \mathrm{g}$ e $50 \mu \mathrm{g})$. O grupo controle foi injetado com o mesmo volume de PBS (A,B,C). A- Estrutura normal da pele, mostrando a epiderme (setas), membrana basal (linha pontilhada branca) e folículos capilares (*), e derme (B) preservados. Hipoderme e a camada de tecido muscular (setas) normais $(\mathbf{C})$. Os grupos injetados com jararagina mostram uma intensa área hemorrágica $(\mathbf{E}, *)$, especialmente na região da hipoderme $(\mathbf{F}, *)$. A camada de tecido muscular esquelético apresentou-se alterado (F, setas). Alterações na epiderme e membrana basal epidermal não foram observadas (D). Nenhuma alteração foi observada nas amostras injetadas com $5 \mu \mathrm{g}$ de $\mathrm{BnP1}(\mathbf{G}, \mathbf{H}, \mathbf{I})$. Alguns pontos hemorrágicos foram observados quando a dose de $50 \mu \mathrm{g}$ de BnP1 foi utilizada $(\mathbf{M}, *)$. Coloração: hematoxilina-eosina. 


\subsubsection{Biodistribuição das SVMPs na pele}

Dando continuidade ao nosso estudo, avaliamos a biodistribuição das toxinas na vasculatura da pele. Usando o anticorpo anti-CD31 como marcador de vasos sanguíneos, observamos que a Jar-alexa488 concentrou-se ao redor de pequenos vasos sangüíneos provavelmente vênulas, após 15 minutos da injeção, período em que a lesão hemorrágica já estava estabelecida. Por outro lado, não verificamos a presença da BnP1-Alexa488 próxima aos vasos sangüíneos, mesmo quando a dose de $50 \mu \mathrm{g}$ foi usada, apresentando-se muito semelhante ao controle BSA-Alexa488 (Figura 24). Interessantemente, a presença da jarCAlexa488, que consiste nos domínios tipo-disintegrina e rico em cisteínas, ausentes na BnP1, também foi detectada ao redor dos vasos, sugerindo que propriedades adesivas presentes nesses domínios são importantes para o acúmulo da toxina próxima aos vasos e conseqüente lesão das células endoteliais (Figura 24). A biodistribuição das toxinas também foi avaliada no tecido muscular localizada abaixo da hipoderme, e constatamos que a jar-Alexa488 e a jarC-Alexa488 concentraram-se, de maneira específica, na membrana basal que envolve as células musculares assim como ao redor dos capilares sangüíneos que irrigam essas células (Figura 25). A cinética da localização da jararagina foi avaliada 15, 22, 30, 45 e 60 minutos após sua injeção e observamos a prevalência desta toxina ao redor de vasos sangüíneos, provavelmente vênulas (Figura 26), assim como em capilares sangüíneos presentes no tecido muscular (Figura 27), em todos os tempos avaliados, mostrando que a ligação da jararagina aos vasos sangüíneos é estável.

Em seguida, avaliamos a afinidade da jararagina pelo colágeno em experimentos ex vivo, através de ensaios de co-localização com o colágeno tipo IV, um importante componente da membrana basal vascular. De acordo com figura 29, a jararagina co-localizou-se com o colágeno IV presente em pequenas vênulas e capilares, cujas membranas basais apresentavam-se interrompidas e com inúmeras irregularidades. Por outro lado, amostras controle injetadas apenas com BSA-Alexa488 não apresentaram marcação específica (Figura 29). Esses dados reforçam a hipótese de que alta afinidade da jararagina ao colágeno IV, não observada para a BnP1, resulta no acúmulo da toxina nas proximidades dos vasos sanguiíneos. 


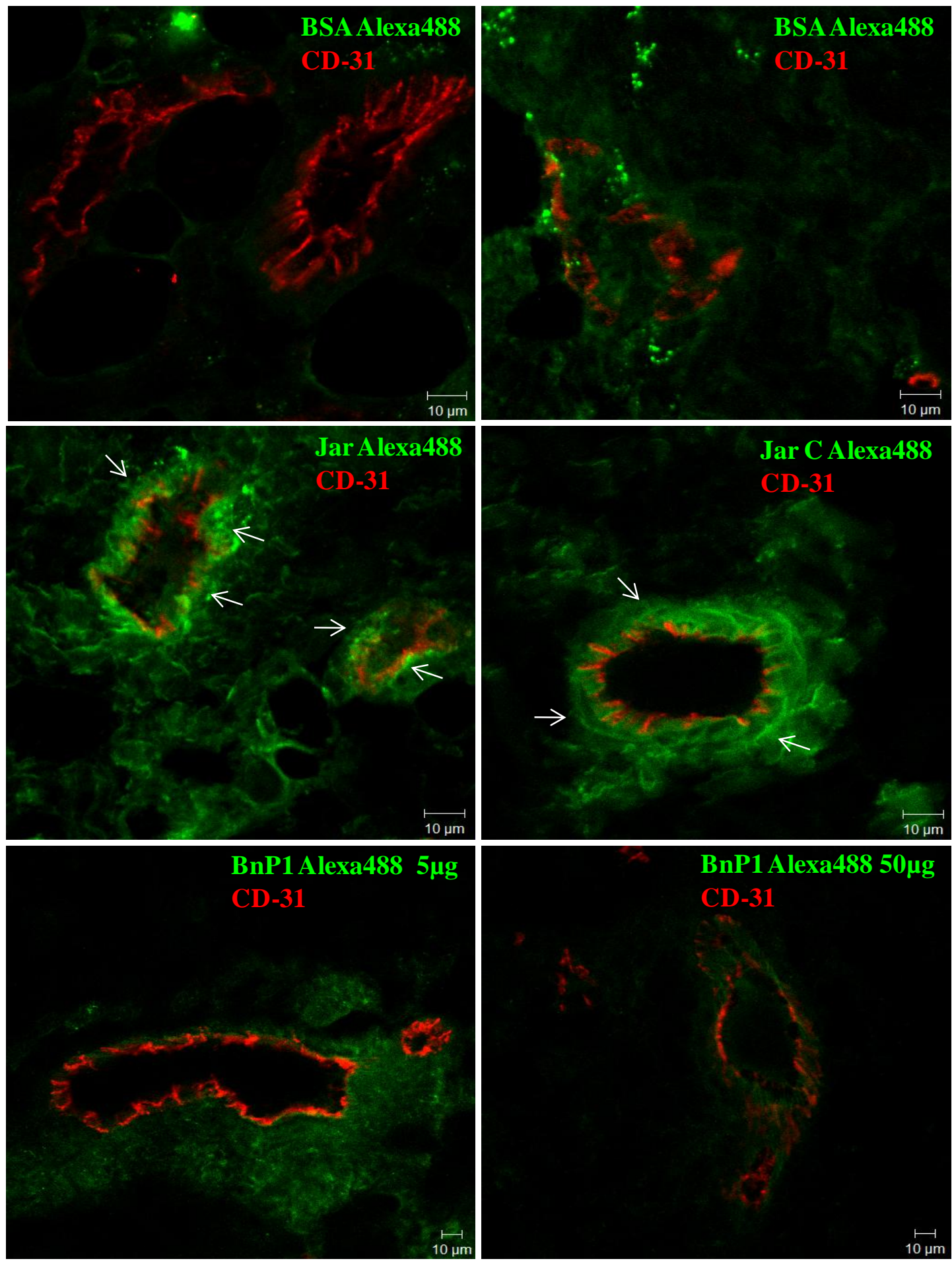

Figura 24- Biodistribuição das SVMPs conjugadas com Alexa488 na pele de camundongos. Cortes de congelação $(5 \mu \mathrm{m})$ da pele do dorso de camundongos foram obtidos após 15 minutos da injeção intradérmica da jararagina, jararagina-C e BnP1 conjugadas ao Alexa488. Os vasos sangüíneos foram marcados com anti-CD31 (1:40), seguida da incubação com anti-IgG de rato conjugado com TRITC (1:500). As setas mostram o acúmulo de jararagina e jararagina-C nas proximidades dos vasos sangüíneos. As lâminas foram analisadas em microscópio confocal (LSM-510-Meta, Zeiss). 


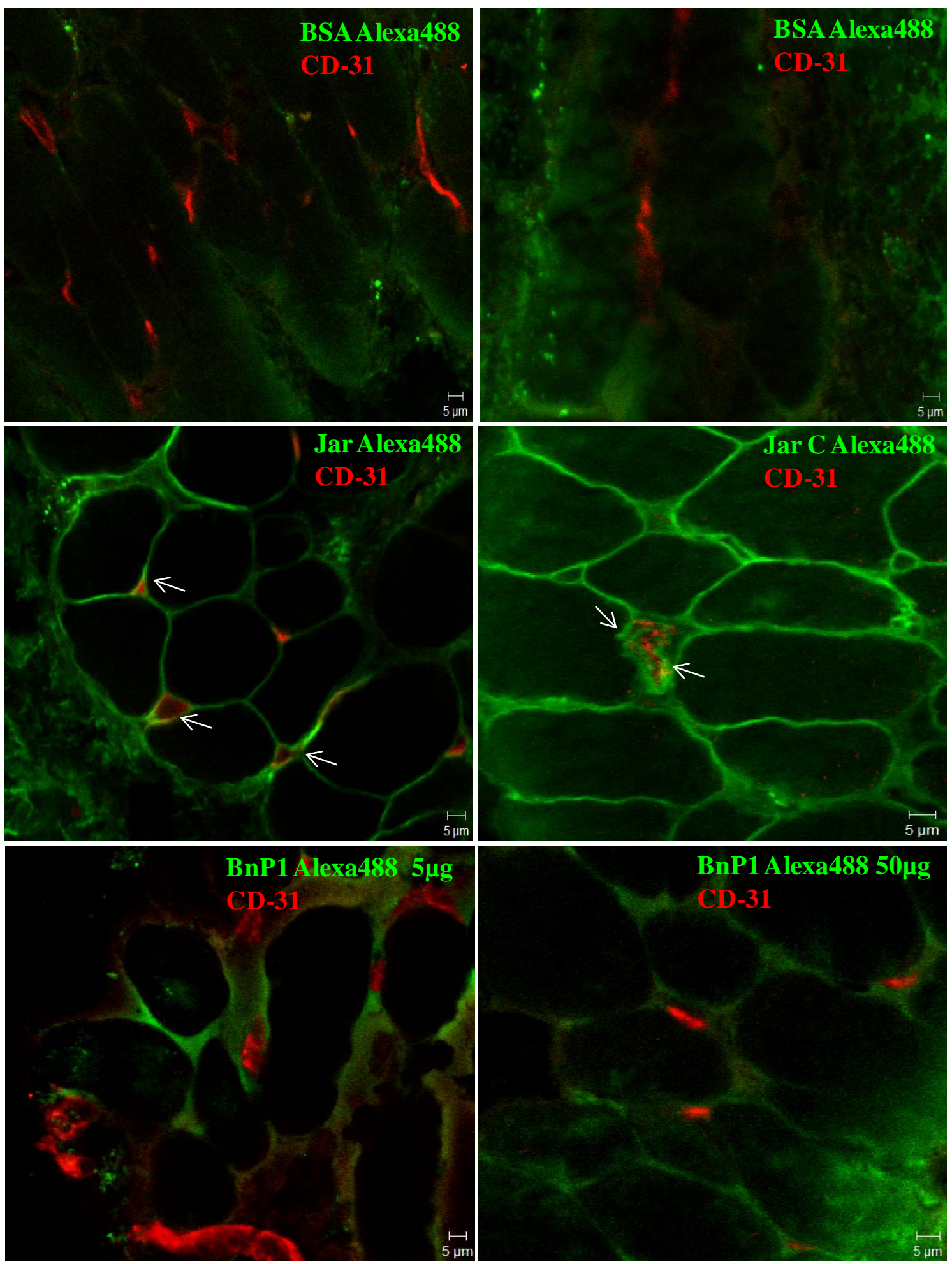

Figura 25-Biodistribuição das SVMPs conjugadas com Alexa488 no tecido muscular. Cortes de congelação $(5 \mu \mathrm{m})$ da pele do dorso de camundongos foram obtidos após 15 minutos da injeção intradérmica da jararagina, jararagina-C e BnP1 conjugadas ao Alexa488. Os vasos sangüíneos foram marcados com anti-CD31 (1:40), seguida da incubação com anti-IgG de rato conjugado com TRITC (1:500). As setas mostram o acúmulo de jararagina e jararagina-C nas proximidades dos capilares sanguíneos que irrigam as células musculares. As lâminas foram analisadas em microscópio confocal (LSM-510-Meta, Zeiss). 


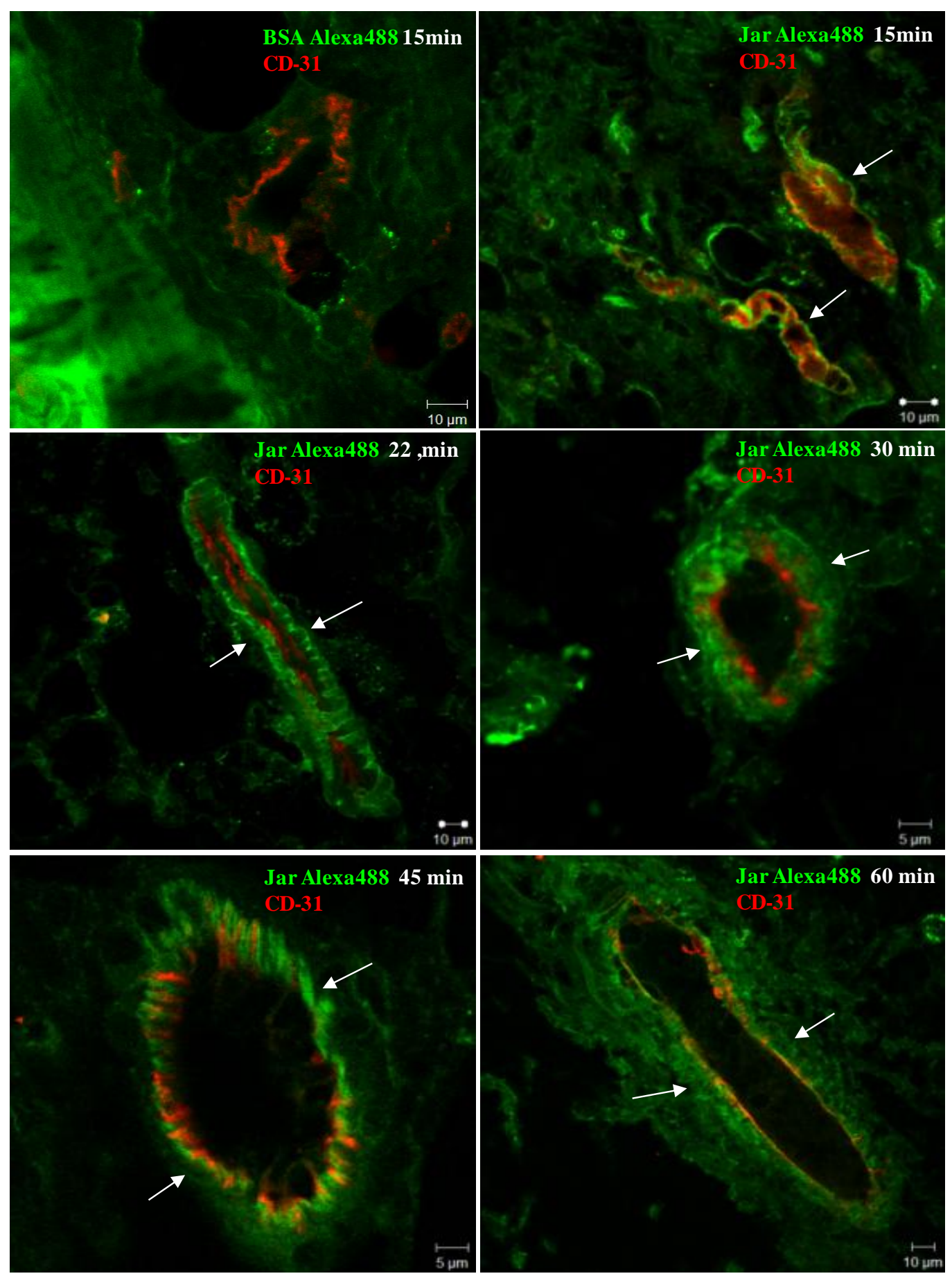

Figura 26- Cinética da distribuição da jararagina conjugada ao Alexa488 na pele de camundongos. Cortes de congelação $(5 \mu \mathrm{m})$ da pele do dorso de camundongos foram obtidos após 15, 22, 30, 45 e 60 minutos da injeção intradérmica da jararagina conjugada ao alexa488. Os vasos sangüíneos foram marcados com anti-CD31 (1:40), seguida da incubação com antiIgG de rato conjugado com TRITC (1:500). As setas mostram a presença da jararagina na parede dos vasos sanguiíneos, provavelmente vênulas, em todos os tempos analisados. As lâminas foram analisadas em microscópio confocal (LSM-510-Meta, Zeiss). 

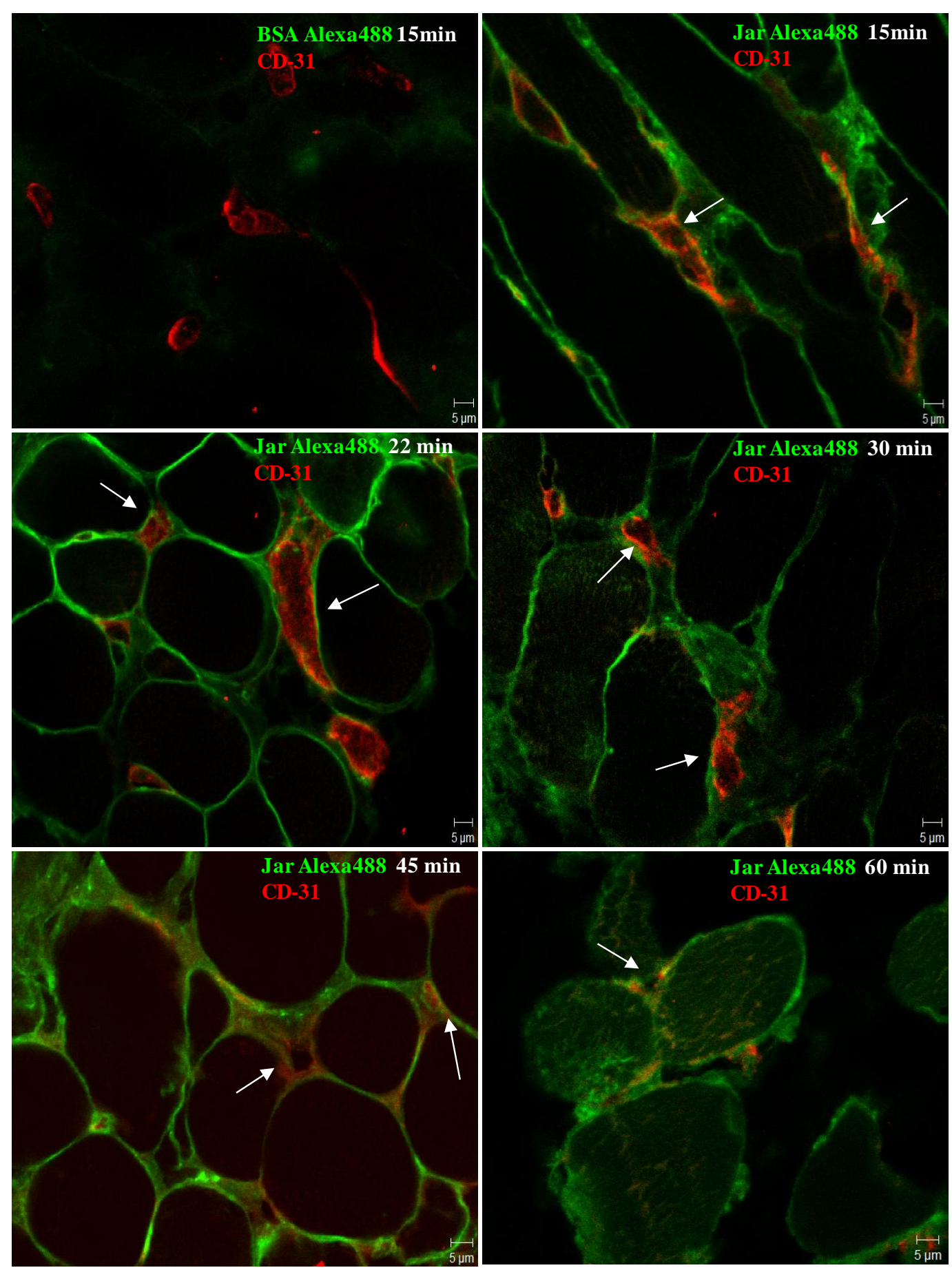

Figura 27- Cinética da distribuição da jararagina conjugada ao Alexa488 no tecido muscular. Cortes de congelação $(5 \mu \mathrm{m})$ da pele do dorso de camundongos foram obtidos após 15, 22, 30, 45 e 60 minutos da injeção intradérmica da jararagina conjugada ao Alexa488. Os vasos sangüíneos foram marcados com anti-CD31 (1:40), seguida da incubação com anti-IgG de rato conjugado com TRITC (1:500). As setas mostram a presença da jararagina na parede dos capilares sangüíneos que irrigam o tecido muscular, em todos os tempos avaliados. As lâminas foram analisadas em microscópio confocal (LSM-510-Meta, Zeiss). 


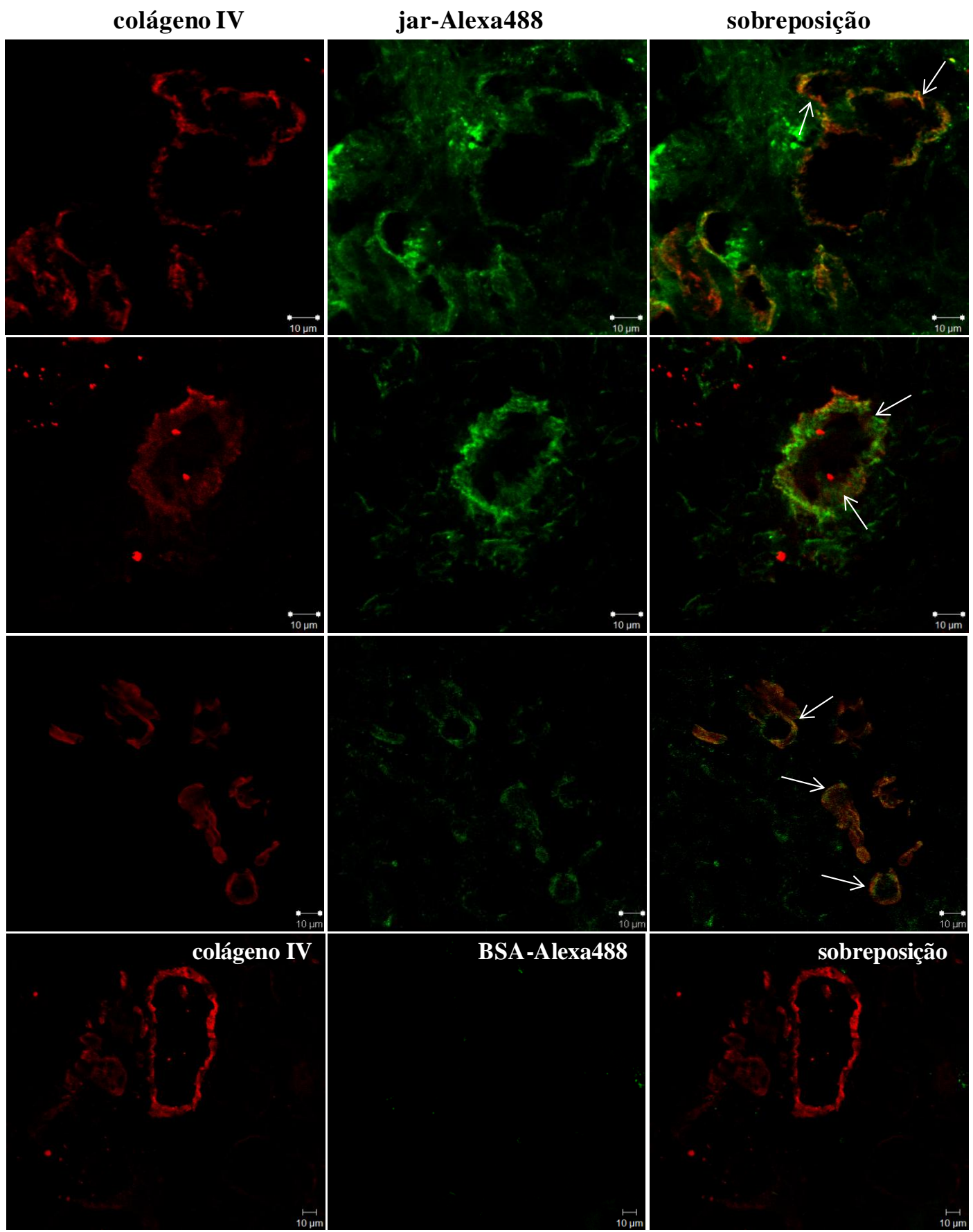

Figura 28- Co-localização da jararagina com o colágeno IV. Cortes de congelação $(5 \mu \mathrm{m})$ da pele do dorso de camundongos foram obtidos 15 minutos após a injeção intradérmica de $10 \mu \mathrm{g}$ de jararagina conjugada com Alexa488. A marcação para o colágeno IV foi realizada com o anti-colágeno IV (1:40), seguida da incubação com anti-IgG de coelho conjugado com TRITC (1:100). A jararagina encontrou-se co-localizada com o colágeno IV presente em pequenos vasos sangüíneos que apresentavam a membrana basal irregular e descontínua (setas). Animais injetados somente com BSA-Alexa488 foram usados como controle negativo. As lâminas foram analisadas em microscópio confocal (LSM-510-Meta, Zeiss). 


\subsubsection{Degradação dos componentes de matriz extracelular}

Em seguida comparamos a degradação dos componentes de matriz extracelular induzida pela jararagina e BnP1, após 15 minutos de injeção. Primeiramente, analisamos a degradação do colágeno fibrilar através de ensaios de histoquímica utilizando a coloração picrossirius-hematoxilina. As amostras controle (Figura 29ABC) apresentaram uma densa trama de fibras de colágeno na região da derme, coradas em vermelho intenso. Essa trama compacta é constituída por fibras grossas, com pouco espaço interfibrilar, caracterizando um tecido conjuntivo muito denso e não modelado. Nas amostras injetadas com a jararagina, observamos a perda da densidade do colágeno com aumento do espaço interfibrilar, fibras com aspecto mais fino (Figura 29DE) e uma intensa degradação do colágeno na região na hipoderme, onde fibras degradadas estão dispersas na matriz extracelular (Figura 29F). Nas amostras injetadas com a BnP1 (5 e $50 \mu \mathrm{g})$, constatamos apenas uma pequena desorganização da matriz de colágeno ao longo da derme (Figura 29GHJL) porém, a degradação da matriz fibrilar na região da hipoderme não foi observada (Figura 29IM). Portanto, esses dados indicam que a diferença do padrão de degradação do colágeno I pode ser conseqüência da alta afinidade da jararagina por esse componente e pode facilitar seu acesso aos vasos sangüíneos.

A degradação dos componentes da membrana basal induzida pela jararagina e BnP1 após 15 minutos de injeção, também foi avaliada. Nesse experimento, avaliamos, através de ensaios de imunofluorescência, os efeitos da jararagina e BnP1 na distribuição do colágeno IV e laminina. As amostras controle mostraram uma típica distribuição do colágeno IV (Figura 30AE) e laminina (Figura 31AE) ao redor de pequenos vasos sangüíneos, provavelmente vênulas, assim como na periferia das células musculares esqueléticas, representando a membrana basal que envolve essas duas estruturas. Nos tecidos tratados com jararagina, verificou-se diminuição do colágeno IV ao redor dos vasos sangüíneos (Figura 30B) e células musculares (Figura 30F), apresentando interrupções ao longo da membrana basal. Por outro lado, observamos que a dose não hemorrágica de BnP1 (Figura 30CG) induziu apenas leves alterações na distribuição do colágeno IV apresentando-se muito semelhante ao controle PBS. Quando uma dose hemorrágica de BnP1 $(50 \mu \mathrm{g})$ foi utilizada, notamos uma desorganização da membrana basal dos vasos sangüíneos (Figura 30D) e células musculares (Figura 30H), apresentando algumas irregularidades ao longo de sua estrutura, especialmente nas células musculares. Entretanto, o efeito da $\mathrm{BnP} 1$ em dose hemorrágica foi menor em relação ao 
observado para a jararagina. A jararagina também foi capaz de alterar a distribuição da laminina ao redor de vasos e células musculares. Porém, esse efeito foi aparentemente mais brando quando comparado ao colágeno IV (Figura 31BF). As amostras injetadas com a BnP1 (5 $\mu \mathrm{g}$ ) apresentaram-se semelhantes ao controle PBS, mostrando apenas pequenas interrupções ao longo da membrana basal (Figura 31CG). A dose de $50 \mu \mathrm{g}$ induziu desorganização da distribuição da laminina, especialmente ao redor dos vasos sangüíneos (Figura 31D). 


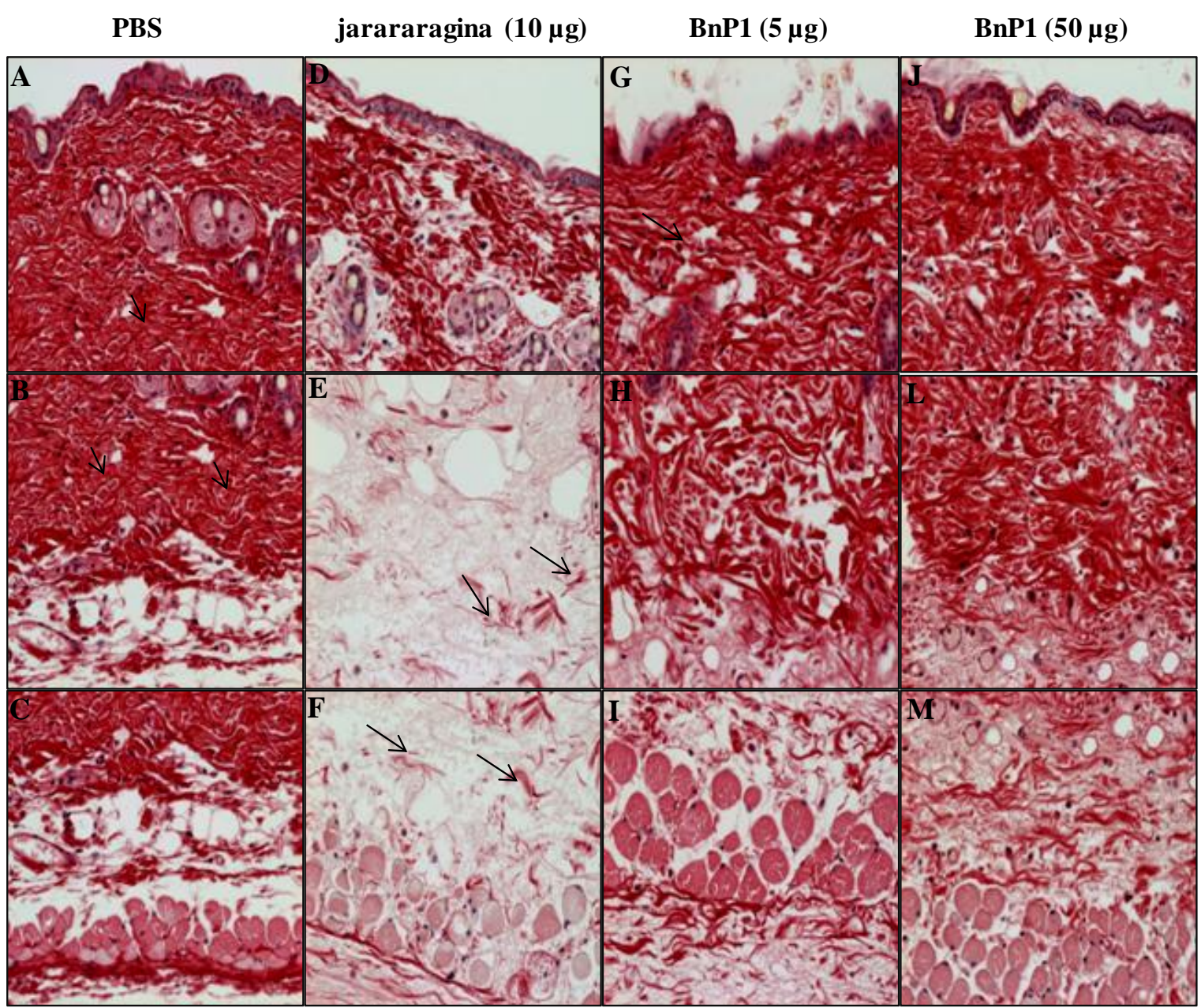

Figura 29- Ação da jararagina e BnP1 na matriz de colágeno fibrilar. Nas amostras injetadas com PBS observa-se a distribuição normal do colágeno I $(\mathbf{A}, \mathbf{B}, \mathbf{C})$, com a presença de fibras grossas com pouco espaço interfibrilar (setas). No grupo injetado com a jararagina observa-se um aumento do espaço interfibrilar e fibras com aspecto mais fino (D,E) e uma intensa degradação do colágeno, especialmente na região da hipoderme, onde fragmentos das fibras de colágeno estão dispersos na matriz extracelular ( $\mathbf{F}$,setas). Nas amostras injetadas com BnP1 (5 e $50 \mu \mathrm{g}$ ) observou-se apenas a perda da densidade das fibras colágenas em alguns pontos. O colágeno fibrilar foi corado com picrossirius-hematoxilina. 


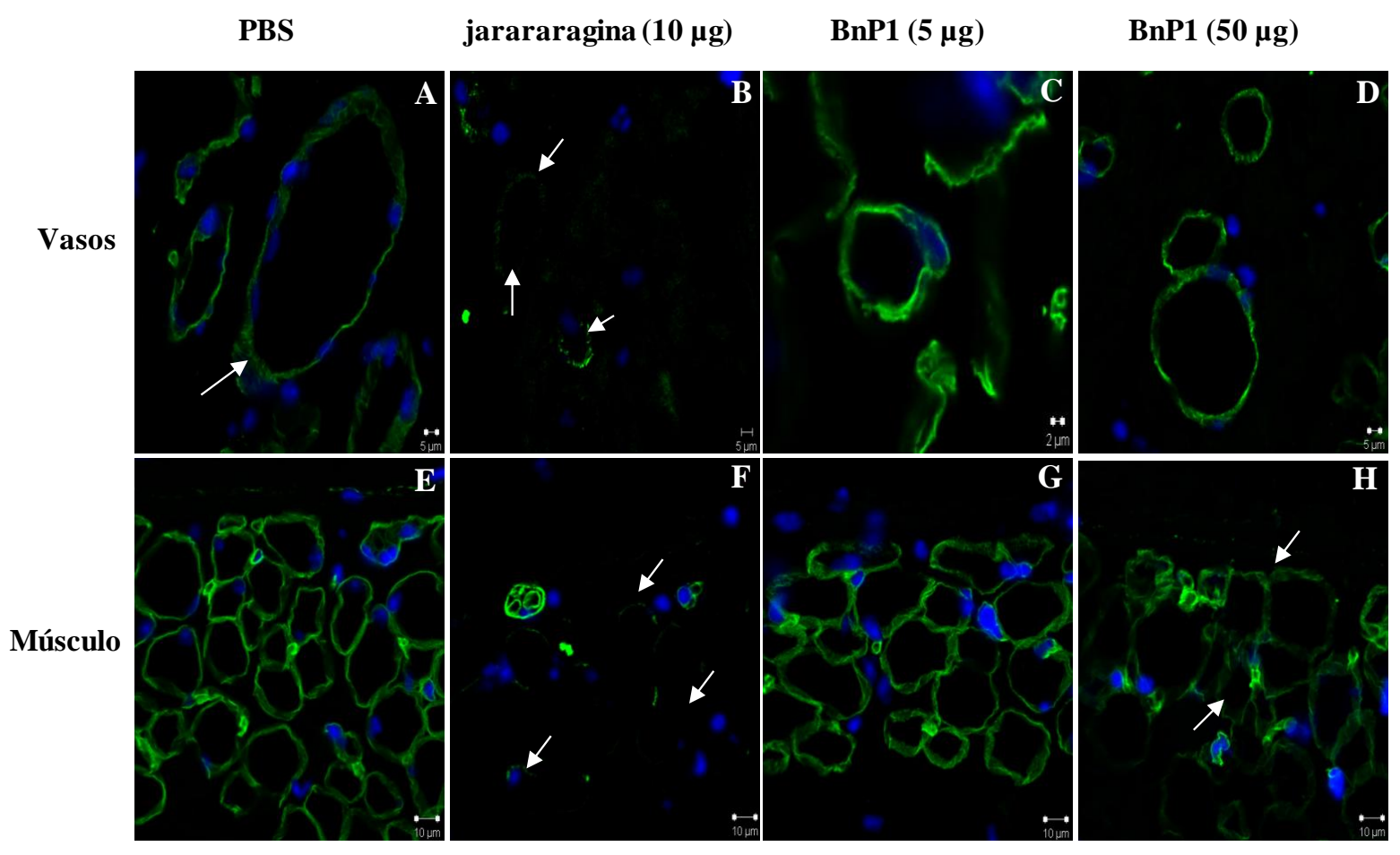

Figura 30- Efeitos da jararagina e BnP1 na distribuição do colágeno IV. Os ensaios de imunofluorescência foram realizados em cortes de $5 \mu \mathrm{m}$ da pele do dorso de camundongos após 15 minutos da injeção intradérmica de jararagina $(10 \mu \mathrm{g})$ ou BnP1 (5 $\mu \mathrm{g}$ e $50 \mu \mathrm{g}$ ). Animais injetados somente com PBS foram usados como controle. A membrana basal foi marcada com anti-colágeno IV (1:40), seguida da incubação com anticorpo secundário específico conjugado com Alexa fluor 488 (1:1000). Os núcleos foram marcados com DAPI (1:1000). A- Amostras controle, injetadas apenas com PBS, mostram uma típica distribuição do colágeno IV ao redor de vênulas (setas) assim como na periferia das células musculares esqueléticas $(\mathbf{E})$. A jararagina alterou a distribuição do colágeno IV ao redor dos vasos sangüíneos $(\mathbf{B})$ e células musculares $(\mathbf{F})$, apresentando interrupções ao longo da membrana basal dessas estruturas (setas). A dose não hemorrágica de BnP1 induziu apenas leves alterações na distribuição do colágeno IV, apresentando-se muito semelhante ao controle PBS. Quando uma dose hemorrágica de BnP1 $\quad(50 \mu \mathrm{g})$ foi utilizada, observou-se uma desorganização da membrana basal dos vasos sangüíneos (D) e células musculares, apresentando algumas irregularidades ao longo de sua estrutura, especialmente no músculo (H, setas). As lâminas foram analisadas em microscópio confocal (LSM-510-Meta, Zeiss). 


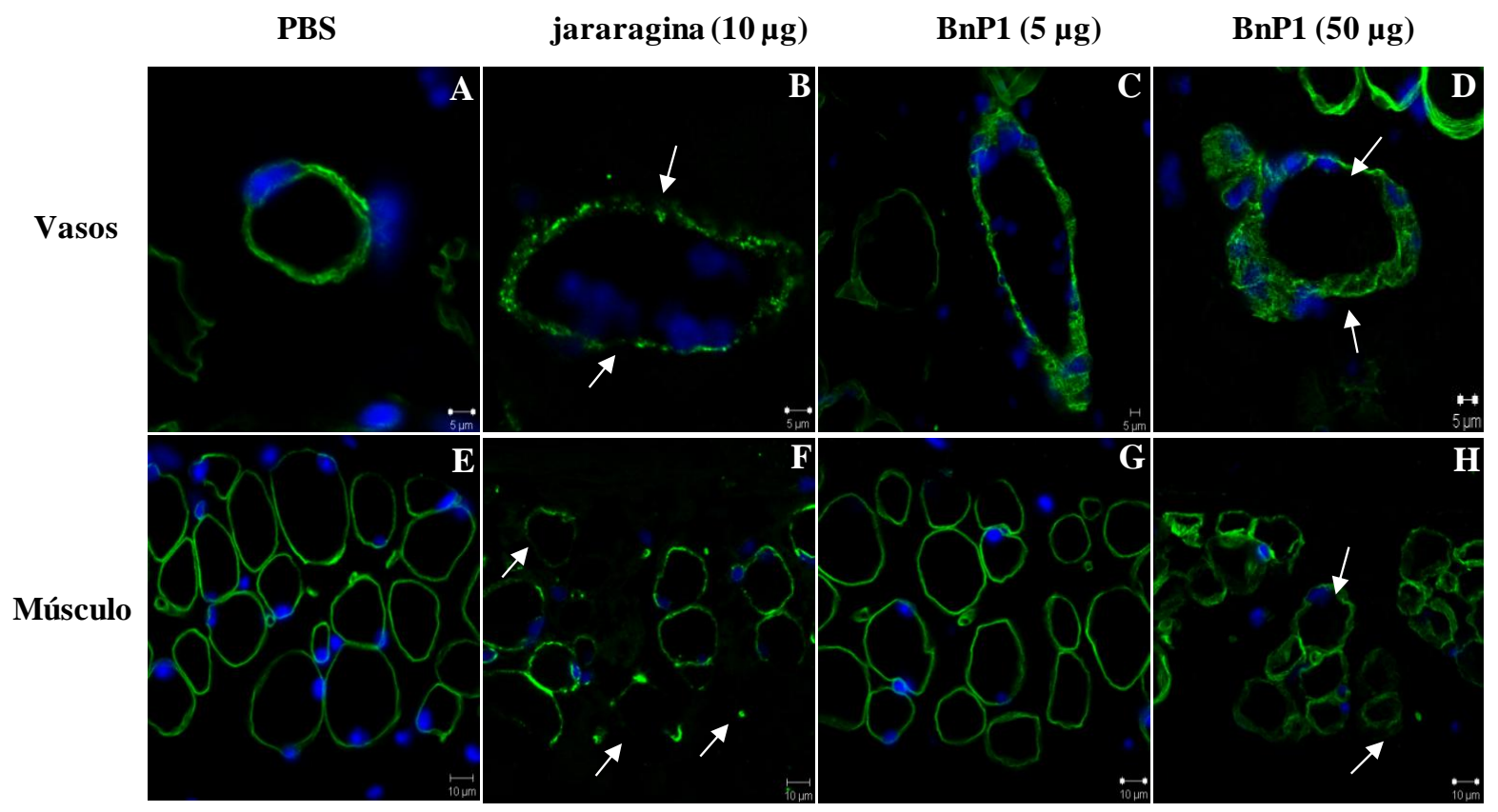

Figura 31-Efeitos da jararagina e $\mathrm{BnP} 1$ na distribuição da laminina. Os ensaios de imunofluorescência foram realizados em cortes de $5 \mu \mathrm{m}$ da pele do dorso de camundongos após 15 minutos da injeção intradérmica de jararagina $(10 \mu \mathrm{g})$ ou BnP1 $(5 \mu \mathrm{g}$ e $50 \mu \mathrm{g})$. Animais injetados somente com PBS foram usados como controle. A membrana basal foi marcada com antilaminina (1:40), seguida da incubação com anticorpo secundário específico conjugado com Alexa fluor 488 (1:1000). Os núcleos foram marcados com DAPI (1:1000). A- Amostras controle, injetadas apenas com PBS, mostram uma típica distribuição da laminina ao redor de vênulas, assim como na periferia das células musculares esqueléticas $(\mathbf{E})$. A jararagina alterou a distribuição da laminina ao redor dos vasos sangüíneos $\quad(\mathbf{B}$, setas) e células musculares (F, setas), apresentando interrupções ao longo da membrana basal dessas estruturas. As amostras injetadas com $5 \mu \mathrm{g}$ de BnP1 apresentaram-se muito semelhantes ao controle PBS $(\mathbf{C , G})$. A dose de $50 \mu \mathrm{g}$ de BnP1 induziu algumas alterações na membrana basal dos vasos sangüíneos e células musculares, apresentando algumas irregularidades ao longo de sua estrutura (D,H, setas). As lâminas foram analisadas em microscópio confocal (LSM-510-Meta, Zeiss). 


\section{DISCUSSÃO}

A ação hemorrágica é uma das consequiências mais graves do envenenamento botrópico, e está relacionada à ação das SVMPs no endotélio vascular. Este efeito é dependente da atividade catalítica, uma vez que o tratamento dessas toxinas com agentes quelantes resulta na completa inibição desta atividade. Contudo, as SVMPs da classe P-I, que possuem ação catalítica semelhante às toxinas da classe P-III, são fracamente hemorrágicas ou não induzem hemorragia, sugerindo a participação dos domínios não catalíticos na expressão da atividade hemorrágica, através de mecanismos não enzimáticos. Alguns autores explicam a discrepância do potencial hemorrágico de SVMPs da classe P-I e P-III baseando-se na presença dos domínios tipo-disintegrina e rico em cisteínas, presentes apenas nas toxinas da classe P-III. Alterações no mecanismo de agregação plaquetária, associadas aos domínios não catalíticos poderiam acentuar a hemorragia, potencializando o extravasamento dos componentes sangüíneos (JIA et al., 1997; KAMIGUTI; HAY; ZUZEL 1996b; KAMIGUTI et al., 2003). Além disso, as SVMPs da classe P-III são menos susceptíveis à ação de inibidores plasmáticos como a $\alpha-2$ macroglobulina, devido ao impedimento estérico promovido pelos domínios tipo disintegrina e rico em cisteínas (BARRAMOVA et al., 1990; ESTEVÃO-COSTA et al., 2000; ESCALANTE et al., 2004). Outra hipótese considera que esses domínios adicionais seriam responsáveis pelo direcionamento do domínio catalítico a sítios específicos da microvasculatura, posicionando as SVMPs próximas a membrana basal dos capilares sangüíneos (JIA et al., 1997; TAKEYA et al., 1990; SERRANO et al., 2006; TANJONI et al., 2003). Entretanto, esses trabalhos não incluem dados experimentais que demonstrem a diferença do potencial hemorrágico entre as diferentes classes de SVMPs. Dessa forma, estudos comparativos utilizando concomitantemente as diferentes classes de proteínas são importantes para testar as diferentes hipóteses e estabelecer o papel dos domínios adicionais ou de outros requisitos estruturais das SVMPs envolvidos com a expressão da atividade hemorrágica.

Neste trabalho analisamos comparativamente a ação de SVMPs da classe PI e P-III em células endoteliais e em componentes da MEC, em modelos in vitro e ex vivo, na tentativa de estabelecer os fatores responsáveis pela diferença de seu potencial hemorrágico. Como modelo de SVMPs utilizamos a jararagina e a BnP1. A jararagina é um excelente modelo de 
SVMP da classe P-III, pois exibe alta atividade hemorrágica, evidenciada nesse trabalho, tanto no dorso de animais experimentais quanto por microscopia intravital. A BnP1 foi escolhida como modelo de P-I, por apresentar baixa atividade hemorrágica, mesmo quando altas doses foram utilizadas.

Um dado muito interessante foi verificado ainda no isolamento das toxinas. $\mathrm{O}$ veneno de B. neuwiedi foi escolhido por conter uma metaloproteinase da classe P-I com fraca atividade hemorrágica, denominada neuwiedase (RODRIGUES et al., 2000), com a qual estávamos trabalhando no Mestrado desenvolvido na Universidade Federal de Uberlândia, MG. No entanto, quando o protocolo de purificação foi adaptado ao sistema FPLC, com veneno coletado no Instituto Butantan, a cromatografia do veneno de B. neuwiedi resultou no isolamento de duas novas SVMPs da classe P-I, denominadas BnP1 e BnP2, diferentes da neuwiedase. $\mathrm{O}$ alinhamento das seqüências parciais da BnP1 e BnP2 com outras SVMPs isoladas mostrou uma grande similaridade das mesmas com a insularinase, um ativador de pró-trombina isolado do veneno de Bothrops insularis (MODESTO et al., 2005), e com a metaloproteinase tipo II do veneno de Bothrops asper (dados não publicados). É interessante notar que a insularinase e a metaloproteinase do tipo P-II de B. asper são derivadas de uma seqüência de DNA precursora de metaloproteinases da classe P-II, que inclui o domínio disintegrina. Entretanto, todos os peptídeos seqüenciados da BnP1 e BnP2 estavam localizados no domínio catalítico. Além disso, a massa molecular da BnP1 e BnP2 corresponde às toxinas da classe P-I, sugerindo a inclusão das toxinas à classe P-I das SVMPs. A similaridade das toxinas isoladas com a neuwiedase foi apenas de $69 \%$, indicando que BnP1 e BnP2 são novas SVMPs da classe P-I presentes no veneno de B. neuwiedi.

A diversidade estrutural e funcional das SVMPs pode ser explicada pela evolução da família gênica que codifica as SVMPs, onde duplicações e divergências de genes ancestrais são muitos comuns (MOURA-DA-SILVA; THEAKSTON; CRAMPTON, 1996b). Por outro lado, diferenças na composição do veneno podem ser devido a diferentes fatores tais como a filogenia, ontogenia e variações geográficas (CHIPPAUX; WILLIAMS; WHITE, 1991). Nesse sentido, é importante ressaltar que a espécie Bothrops neuwiedi está dividida em várias subespécies que encontram-se distribuídas em todo o território nacional (PAULINO; MAGALHÃES; SILVA, 1991). Portanto, as diferenças encontradas entre as toxinas isoladas e a neuwiedase podem ser resultantes de diferentes regiões de coleta do veneno.

A próxima etapa do trabalho foi comparar a ação da BnP1 e jararagina quanto à atividade hemorrágica, miotóxica, ação em componentes da MEC e em células endoteliais e 
musculares. Os resultados descritos abaixo, juntamente com a caracterização estrutural da BnP1, foram publicados (BALDO et al., 2008) e o trabalho encontra-se anexado (ANEXO 1).

Uma vez que alterações no sistema hemostático podem contribuir na indução da hemorragia, a ação proteolítica da jararagina e BnP1 em proteínas plasmáticas foi comparada. Enzimas proteolíticas presentes nos venenos são classificadas de acordo com a especificidade de hidrólise das cadeias do fibrinogênio (MARKLAND, 1998). O fibrinogênio é uma glicoproteína plasmática dimérica de $340-\mathrm{kDa}$, formada por duas cadeias polipeptídicas dispostas em pares $(2 \mathrm{~A} \alpha, 2 \mathrm{~B} \beta)$ e uma cadeia $\gamma$. As SVMPs, geralmente, degradam preferencialmente a cadeia A $\alpha$ e são classificadas como $\alpha$-fibrinogenases (MARKLAND, 1998; SWENSON; MARKLAND, 2005). De acordo com a literatura, a jararagina cliva o fibrinogênio na porção C-terminal da cadeia $\mathrm{A} \alpha$ e libera um fragmento de $23 \mathrm{kDa}$ (KAMIGUTI et al., 1994a). Entretanto, a molécula de fibrinogênio permanece funcional na agregação plaquetária. A única conseqüência da atividade $\alpha$-fibrinogenase da jararagina é a polimerização anormal da fibrina (KAMIGUTI et al., 1994a). Neste trabalho, mostramos que a jararagina e BnP1 degradaram preferencialmente a cadeia $\mathrm{A} \alpha$, sugerindo a inclusão da $\mathrm{BnP} 1$ na classe das $\alpha$-fibrinogenases. As toxinas também foram capazes de degradar a cadeia B $\beta$. No entanto, a degradação das duas cadeias pela jararagina foi mais rápida que pela BnP1. A degradação da fibrina também foi observada para as duas toxinas, e novamente a jararagina mostrou-se mais eficiente na degradação deste substrato.

A literatura descreve diversas SVMPs da classe P-I e P-III com ação fibrino(geno)lítica e esse efeito é dependente de atividade catalítica (MARKLAND, 1998; SWENSON; MARKLAND, 2005). Entretanto, a comparação da atividade específica dessas enzimas é dificultada, uma vez que diferentes tempos e concentrações são utilizados nos diferentes trabalhos. Em nosso trabalho, verificamos que as toxinas da classe P-III foram mais eficientes que as toxinas da classe P-I na degradação de proteínas plasmáticas e isso pode ser um dos fatores responsáveis pela diferença de potencial hemorrágico entre as SVMPs. No entanto, a degradação de substratos plasmáticos não explica de maneira satisfatória essa diferença, uma vez que a ação hemorrágica é melhor caracterizada pela degradação dos componentes da membrana basal vascular, com conseqüente dano nas células endoteliais.

Neste sentido, a capacidade de degradação de componentes da matriz extracelular pela jararagina e $\mathrm{BnP} 1$ também foi comparada em experimentos in vitro. Nestes experimentos, verificamos que jararagina e a BnP1 não foram capazes de degradar a laminina, e resultados 
não reprodutíveis foram obtidos nos experimentos utilizando o colágeno $\mathrm{I}$, mostrando diferentes padrões de degradação (dados não mostrados). De acordo com a literatura, as SVMPs da classe P-I e P-III são capazes de hidrolisar, de maneira similar, muitos componentes da MEC, tais como o matrigel (BJARNASON; HAMILTON; FOX, 1988) e componentes isolados de matriz extracelular, como o colágeno IV, laminina e fibronectina (BJARNASON; HAMILTON; FOX, 1988; BARRAMOVA et al., 1989; MARUYAMA et al., 1992; RUCAVADO et al., 1999; WANG; SHIH; HUANG, 2004; DE MORAES; SELISTRE-DE-ARAÚJO, 2006). De maneira geral, as SVMPs não são capazes de hidrolisar os colágenos fibrilares, tais como os colágenos tipo I e III (BARRAMOVA et al., 1989). No entanto, alguns trabalhos descreveram a degradação do colágeno I por SVMPs da classe P-I (RUCAVADO et al., 1995; RODRIGUES et al., 2000; MARCUSSI et al., 2007). Essa discrepância quanto à degradação do colágeno fibrilar pelas SVMPs pode ser explicada pelo estado de desnaturação das amostras utilizadas. O colágeno I com sua estrutura tripla-hélice preservada é bastante resistente à ação das SVMPs, enquanto em condições desnaturantes, seria facilmente degradado por essas enzimas. Desta forma, as diferenças no comportamento de hidrólise in vitro de componentes da MEC pelas SVMPs podem ser simplesmente resultado das diferentes condições experimentais utilizadas, e não explicam a diferença de potencial hemorrágico observado entre as diferentes classes de SVMPs. Entretanto, em estudos comparativos onde SVMPs das classes P-I e P-III foram utilizadas concomitantemente, foram descritas algumas diferenças no padrão de hidrólise in vitro do nidogênio/entactina (ESCALANTE et al., 2006). O nidogênio/entactina, uma proteína de 150 kDa formada por três domínios globulares, é responsável pela interação entre importantes componentes da membrana basal, formando uma estrutura estável e uniforme. O domínio G2 do nidogênio está envolvido na interação entre o colágeno IV e o perlecan, enquanto que o domínio G3 faz uma ponte com a laminina (KALLURI, 2003). A jararagina, SVMP hemorrágica da classe P-III, foi capaz de clivar a molécula de nidogênio numa região próxima ao local de interação com o colágeno IV e laminina. Por outro lado, a clivagem do nidogênio pela BaP1, SVMP classe P-I fracamente hemorrágica, ocorreu em uma região onde não há interações com esses componentes, sugerindo que esta diferença de clivagem poderia ser responsável pelo maior atividade hemorrágica da jararagina (ESCALANTE et al., 2006). No entanto, esta hipótese não foi comprovada através de experimentos in vivo.

Um comportamento semelhante de SVMPs das classes P-I e P-III também foi observado quando comparamos a ação da jararagina e $\mathrm{BnP} 1$ em cultura de células endoteliais. 
De acordo com a literatura, um grande número de SVMPs induz apoptose em células endoteliais por diferentes mecanismos (MOURA-DA-SILVA; BUTERA; TANJONI, 2007). O efeito pró-apoptótico da jararagina foi anteriormente descrito pelo nosso grupo (TANJONI et al., 2005). O tratamento de uma linhagem endotelial murina (tEnd) com essa toxina resultou na redução da adesão e viabilidade celular. Esse efeito foi caracterizado pela retração no citoesqueleto celular, rearranjo do citoesqueleto de F-actina e a e redução do conteúdo de FAK (Focal Adhesion Kinase) associada com o citoesqueleto de actina e proteínas fosforiladas, indicando uma interferência na adesão focal. Esses efeitos resultaram na ativação da pró-caspase 3 e alteração nos níveis de expressão da proteína pró-apoptótica Bax, sugerindo apoptose por perda da adesão da célula aos componentes da MEC, denominada anoikis. Esses efeitos foram dependentes da atividade catalítica da jararagina. Neste trabalho, verificamos que a apoptose também foi o principal mecanismo envolvido na redução da viabilidade celular induzida pela BnP1 e a jararagina em HUVECs. Além disso, as toxinas não interferiram na viabilidade celular de células $\mathrm{C} 2 \mathrm{C} 12$, mostrando a seletividade da jararagina e $\mathrm{BnP} 1$ por células endoteliais. A ação da jararagina e $\mathrm{BnP} 1$ no citoesqueleto de HUVECs também foi avaliada. Após 10 minutos de tratamento, verificamos que a jararagina induz retração no citoesqueleto celular, evidenciado pela coloração da F-actina e de microtúbulos. Aparentemente, a jararagina promoveu alterações morfológicas mais evidentes que a BnP1, porém as duas SVMPs induziram apoptose de maneira similar.

De acordo com os resultados deste trabalho, a apoptose de células endoteliais in vivo pode não representar um fator chave para a indução da hemorragia, uma vez que não foram observadas diferenças significativas entre a ação da jararagina e $\mathrm{BnP} 1$ em células endoteliais. Numa recente publicação, Jimenez et al. (2008), avaliaram a importância da apoptose para a patologia local induzida por SVMPs. Os autores não detectaram a presença de apoptose in vivo após 6 horas de injeção intradérmica de BaP1 na pele de camundongos, sugerindo que esse mecanismo de morte celular, não está envolvido no dano do endotélio vascular que resulta em hemorragia, já estabelecida neste intervalo de tempo. Nossos dados mostrando que toxinas com diferente capacidade em induzir hemorragia induziram níveis semelhantes de apoptose, corroboram com a evidência de Jimenez et al. (2008), diminuindo a importância atribuída a apoptose nas lesões hemorrágicas induzidas por SVMPs.

Em conjunto, nossos resultados indicaram que a BnP1 possui ação similar à jararagina em relação à hidrólise de proteínas plasmáticas e de matriz extracelular e ação em células endoteliais, indicando que a presença dos domínios tipo-disintegrina e rico em cisteínas não 
são essenciais para a expressão dessas atividades biológicas. Portanto, esses dados não explicam a diferença do potencial hemorrágico entre SVMPs das classes P-I e P-III.

Um parâmetro pouco abordado na literatura consiste em eventuais diferenças na biodistribuição das toxinas nos tecidos injuriados. As diferenças entre o potencial hemorrágico das SVMPs poderiam ser resultantes da maior ou menor acessibilidade dessas toxinas aos seus alvos de ação. Esta hipótese pode ser respaldada pela presença do domínio tipo-disintegrina, que vem sendo correlacionado com propriedades adesivas aos componentes da matriz extracelular, como por exemplo, o colágeno I (ZHOU; DANGELMAIER; SMITH, 1996; LIU; HUANG, 1997), ou com a sua capacidade de ligação à integrinas presentes em células endoteliais e plaquetas (MOURA-DA-SILVA et al., 2001). A afinidade da jararagina pelo colágeno tipo I foi anteriormente mostrada pelo nosso grupo (TANJONI et al., 2003), e pode ser um fator importante na indução da hemorragia, uma vez que pode concentrar as toxinas no local da injeção e retardar sua distribuição tecidual, acentuando assim a degradação dos componentes da membrana basal vascular. Além disso, anticorpos monoclonais que inibem a ligação da jararagina ao colágeno também inibem sua ação hemorrágica (TANJONI et al., 2003), respaldando a hipótese de que a ligação ao colágeno seria importante no estabelecimento da lesão hemorrágica.

Recentemente, investigamos a importância da ligação ao colágeno para a indução da hemorragia, através de um estudo comparativo entre a jararagina e berythractivase (MOURADA-SILVA et al., 2008). A berythractivase, isolada de B. erythromelas, é um ativador de prótrombina pertencente à classe P-III das SVMPs e apresenta grande similaridade estrutural com a jararagina incluindo a presença dos domínios tipo disintegrina e rico em cisteínas, mas não induz hemorragia. A berythractivase não foi capaz de se ligar ao colágeno e não foi reconhecida pelo anticorpo monoclonal MAJar3, um anticorpo que reconhece a porção Cterminal do domínio tipo-disintegrina da jararagina e é capaz de neutralizar a ligação ao colágeno e a atividade hemorrágica da jararagina e de vários venenos botrópicos. A reatividade do MAJar3 com a BnP1 também não foi observada, mesmos quando altas concentrações de anticorpo foram usadas (dados não mostrados).

$\mathrm{Na}$ tentativa de mapear o epitopo reconhecido pelo MAjar3, que corresponderia ao sítio putativo de ligação ao colágeno, as duas SVMPs foram comparadas quanto às suas características estruturais com enfoque no domínio tipo disintegrina, sabidamente o alvo de ligação do MAjar3 (TANJONI et al., 2003). A jararagina e a berythractivase apresentaram $73,6 \%$ de identidade no domínio tipo-disintegrina. No entanto, substituições não 
conservativas foram observadas na região putativa de ligação com integrinas, sugerindo que diferenças estruturais dentro desse domínio sejam responsáveis pela diferença de afinidade dessas toxinas ao MAJar3 e ao colágeno, com conseqüente diferença no seu potencial hemorrágico. Usando a modelagem molecular e a reatividade com o anticorpo MAJar3, o sítio de ligação da jarararagina ao colágeno foi identificado no subdomínio Da do domínio tipo disintegrina, e estava ausente na berythractivase. Interessantemente, esse epitopo é conservado em SVMPs hemorrágicas da classe P-III tais como a catrocolastatina, acurhagin e acutolysina, e não foi encontrado na ecarina uma SVMP da classe P-III não hemorrágica (MOURA-DA-SILVA et al., 2008). Partes desses resultados estão descritos nesta tese e o trabalho completo encontra-se anexado (ANEXO 2).

Nesse trabalho, verificamos que tanto a jararagina quanto a jararagina-C se ligaram com alta afinidade ao colágeno I e IV, confirmando que o domínio tipo disintegrina está envolvido na ligação ao colágeno. O colágeno constitui uma família de proteínas alongadas que representa cerca de $25 \%$ da massa total de proteínas dos mamíferos (LEITINGER; HOHENESTER, 2007). Todos os colágenos são constituídos por três cadeias polipeptídicas dispostas em tripla hélice, chamadas cadeias $\alpha$. Essas cadeias são formadas por uma seqüência repetitiva de três resíduos de aminoácidos, Gly-X-Y, onde $\mathrm{X}$ e $\mathrm{Y}$ freqüentemente são prolina ou hidroxiprolina e lisina ou hidroxilisina, respectivamente. A presença da glicina a cada três posições é essencial para a formação da tripla hélice conferindo à molécula grande flexibilidade (MYLLYHARJU; KIVIRIKKO, 2004). Todas as cadeias $\alpha$ contêm domínios não colágenos (NC-Non Collagenous domains) ou domínios globulares. Nos colágenos que formam fibras, como o colágeno tipo I, esses domínios são removidos proteoliticamente permitindo a associação lateral das fibrilas (CANTY; KADLER, 2005). O colágeno tipo IV é um colágeno não fibrilar, que difere dos colágenos fibrilares devido a presença de domínios globulares (KALLURI, 2003; LEBLEU; MACDONALD; KALLURI, 2007).

Nossos resultados mostraram que a jararagina se ligou indiscriminadamente à molécula de colágeno I, uma vez que não foram observadas diferenças de afinidade da jararagina aos mini-colágenos (FC0 e FC3) e à molécula intacta de colágeno I. O fragmento FC0 é composto por uma seqüência de aminoácidos (GPP) responsável pela formação da tripla hélice da molécula de colágeno I. O fragmento FC3 possui a mesma estrutura do FC0, mas com a presença da seqüência GFPGER, que consiste no sítio de ligação à integrina $\alpha_{2} \beta_{1}$. Esses resultados sugerem que a interação da jararagina ao colágeno é independente do sítio de interação à integrina $\alpha_{2} \beta_{1}$. Entretanto, a ligação da jararagina ao colágeno I desnaturado foi 
drasticamente reduzida, indicando que está interação é dependente da estrutura em tripla hélice do colágeno.

A alta afinidade da jararagina ao colágeno pode ter implicações na inibição de agregação plaquetária induzida por essa toxina. As SVMPs da classe P-III inibem a agregação plaquetária induzida pelo colágeno através da interação com a integrina $\alpha_{2} \beta_{1}$ presente na membrana plaquetária (KAMIGUTI, 2005) através do bloqueio do receptor $\alpha_{2} \beta_{1}$ (DE LUCA et al., 1995), ou pela clivagem proteolítica da subunidade $\beta_{1}$ deste mesmo receptor (KAMIGUTI; HAY; ZUZEL, 1996b). Entretanto, a alta afinidade da jararagina a regiões genéricas da molécula de colágeno pode indicar que a inibição da agregação plaquetária induzida pelo colágeno inclui a ação em outros receptores celulares, tais com a GPVI. Embora não existam evidências da ligação da jararagina com a GPVI, essa toxina poderia, em primeiro momento, impedir a ligação do colágeno ao receptor GPIV, e conseqüentemente afetar a sinalização via integrina $\alpha_{2} \beta_{1 \mathrm{e}} \alpha_{\mathrm{IIb}} \beta_{3}$, fundamentais para a agregação plaquetária.

Alguns trabalhos mostraram que o domínio rico em cisteínas também está envolvido em propriedades adesivas a componentes de matriz extracelular. Serrano et al. (2005) verificaram que a atrolisina $\mathrm{A}$, isolada do veneno de Crotalus atrox, assim como seus domínios tipo disintegrina e rico em cisteínas recombinantes, são capazes de se ligar ao colágeno I e ao WVF, via domínio rico em cisteínas. Além disso, o domínio rico em cisteínas de SVMPs da classe P-III, como a jararagina, interage com proteínas que contém o domínio A do VWF tais como o colágeno XIV, XII e matrilinas 1, 3 e 4, resultando na conseqüente degradação destes substratos (SERRANO et al., 2006). A ligação das SVMPs que contêm o domínio A do VWF ocorreria via região hipervaríavel presente no domínio rico em cisteínas, consistindo no sítio de ligação ao substrato para a proteólise dos mesmos. Entretanto, esse mecanismo é distinto do verificado neste trabalho onde, após a ligação ao colágeno, a toxina ainda estaria livre para hidrolisar outras macromoléculas.

No sentido de avaliar experimentalmente a hipótese de que a ligação de alta afinidade da jararagina ao colágeno favoreceria a expressão da atividade hemorrágica, nossa primeira abordagem foi verificar a atividade hemorrágica e atividade proteolítica do complexo jararagina-colágeno, obtido in vitro. Nossos resultados mostraram que a jararagina complexada ao colágeno não é capaz de induzir a hemorragia, embora o sítio catalítico continue exposto para a catálise, como verificado pela manutenção da atividade fibrinolítica do complexo jararagina-colágeno. Esses dados corroboram com nossa hipótese de que a 
ligação ao colágeno facilitaria o acesso da toxina aos vasos sangüíneos, tornando assim a catálise mais eficiente e explicando a diferença de potencial hemorrágico entre as SVMPs.

Esta hipótese foi então investigada in vivo, usando a pele de camundongos como modelo experimental para o estudo comparativo da jararagina, toxina altamente hemorrágica, e a BnP1, SVMP fracamente hemorrágica. Após a injeção intradérmica de doses equimolares das toxinas, verificamos que apenas a jararagina induziu intensa degradação dos componentes da matriz extracelular induzindo lesão hemorrágica predominantemente na região da hipoderme. Pequenas lesões hemorrágicas induzidas pela BnP1 ocorreram apenas com uma dose 50 vezes maior do que a dose utilizada nos animais injetados com a jararagina. A jararagina e a BnP1 não induziram alterações na epiderme e membrana basal epidermal. Utilizando o mesmo modelo experimental alguns autores observaram que a $\mathrm{BaP} 1$, toxina hemorrágica da classe P-I, induziu hemorragia na hipoderme e derme (RUCAVADO; NÚNEZ; GUTIÉRREZ, 1998), além de alterações na interface derme-epiderme, após 3 horas da injeção de $60 \mu \mathrm{g}$ dessa toxina (RUCAVADO et al., 2002). Além disso, Jimenez et al. (2008), utilizando a pele da orelha de camundongos, verificaram alterações na distribuição do colágeno IV e laminina presentes na membrana basal epidermal 6 horas após a injeção intradérmica da mesma toxina. Esses efeitos, provavelmente, são resultado da dose de BaP1 escolhida para o experimento, uma vez que essa toxina induz hemorragia somente quando altas doses são usadas, mas também podem ser devido ao um efeito indireto das toxina, devido à interrupção do fluxo sangüíneo nas áreas afetadas. Uma vez que nosso interesse está no estudo nas alterações diretas provocadas pelas toxinas durante a lesão aguda, utilizamos tempos inferiores, onde alterações na epiderme e membrana basal epidermal não foram observadas.

Nosso próximo passo foi avaliar a biodistribuição das toxinas na microsvasculatura da pele, utilizando uma abordagem inédita ainda não descrita na literatura. Usando CD-31 como um marcador de vasos sangüíneos, verificamos que a jararagina encontrou-se localizada na parede de vasos de diferentes calibres, tais como capilares e vênulas, por um período de até 60 minutos. Por outro lado, a presença da BnP1 não foi detectada, mesmo em altas doses foram utilizadas. Interessantemente, a jararagina-C apresentou um padrão de acúmulo semelhante ao observado para a jararagina, mostrando que os domínios tipo disintegrina e rico em cisteínas são importantes para esse evento. Outro dado muito importante foi a co-localização da jararagina ao colágeno IV, mostrando que a ligação dessa toxina ao colágeno também ocorre in vivo. 
Em seguida, comparamos os efeitos induzidos pela jararagina e pela $\mathrm{BnP} 1 \mathrm{em}$ componentes da matriz extracelular. A marcação do colágeno fibrilar, mostrou que a jararagina induziu evidente degradação das fibras de colágeno na região da hipoderme, local onde observou-se o principal foco hemorrágico. Por outro lado, a BnP1 não foi capaz de alterar a distribuição do colágeno fibrilar, mesmo quando altas doses foram utilizadas. Além disso, a jararagina também foi capaz de degradar o colágeno IV presente nas MB dos vasos sangüíneos e das células musculares, enquanto que esse mesmo efeito não foi detectado para a BnP1. A jararagina também afetou a distribuição da laminina ao redor dos vasos sangüíneos e células musculares, mas esse efeito não foi tão intenso quanto ao verificado para o colágeno IV, mostrando que os colágenos são os principais alvos de ação das SVMPs hemorrágicas. Resultados semelhantes foram obtidos por Escalante et al. (2006). Usando o músculo gastrocnêmio como modelo experimental, esses autores detectaram alterações na morfologia dos capilares sangüíneos e componentes da membrana basal vascular, tais como laminina, colágeno IV, entactina/nidogênio, após injeção intramuscular de $5 \mu \mathrm{g}$ de jararagina e $15 \mu \mathrm{g}$ de $\mathrm{BaP} 1$, que correspondem a doses hemorrágicas dessas toxinas. No entanto, nenhuma diferença no padrão de degradação dos componentes da membrana basal in vivo foi detectada, uma vez que doses hemorrágicas das duas toxinas foram utilizadas.

As toxinas da classe P-I podem apresentar diferentes graus de atividade hemorrágica, ou seja, podem variar desde a ausência desta atividade ou apresentar atividade hemorrágica fraca, quando comparada a uma toxina de classe P-III. Essa diferença pode ser simplesmente devido à dose de toxina usada, uma vez que as toxinas da classe P-I só induzem hemorragia quando altas concentrações. No entanto, a comparação de SVMPs da classe P-I hemorrágicas e não hemorrágicas mostrou diferenças em uma seqüência de aminoácidos localizada próxima ao sítio catalítico que pod estar envolvida na interação com componentes da MEC (WATANABE et al., 2003). Esses resultados indicam que outros requisitos estruturais das SVMPs podem estar envolvidos na expressão da atividade hemorrágica.

Neste trabalho, verificamos que SVMPs da classe P-I e P-III diferem quanto à ligação ao colágeno, biodistribuição e degradação dos componentes da matriz extracelular in vivo, eventos que podem explicar a diferença entre seu potencial hemorrágico.

Com base nesses resultados, sugerimos a ligação de alta afinidade de toxinas hemorrágicas ao colágeno como um novo mecanismo envolvido na atividade hemorrágica das SVMPs, conforme representado na figura 32. Esta ligação ocorre através do domínio tipodisintegrina e promove o acúmulo das toxinas nas proximidades dos vasos sangüíneos, 
tornando assim a catálise dos componentes da $\mathrm{MB}$ mais eficiente e resultando na forte atividade hemorrágica induzida pela toxinas da classe P-III. Por outro lado, toxinas que não se ligam ao colágeno são rapidamente absorvidas agindo preferencialmente de maneira sistêmica ou induzindo hemorragia apenas em altas doses, como ocorre no caso das SVMPs da classe P-I.

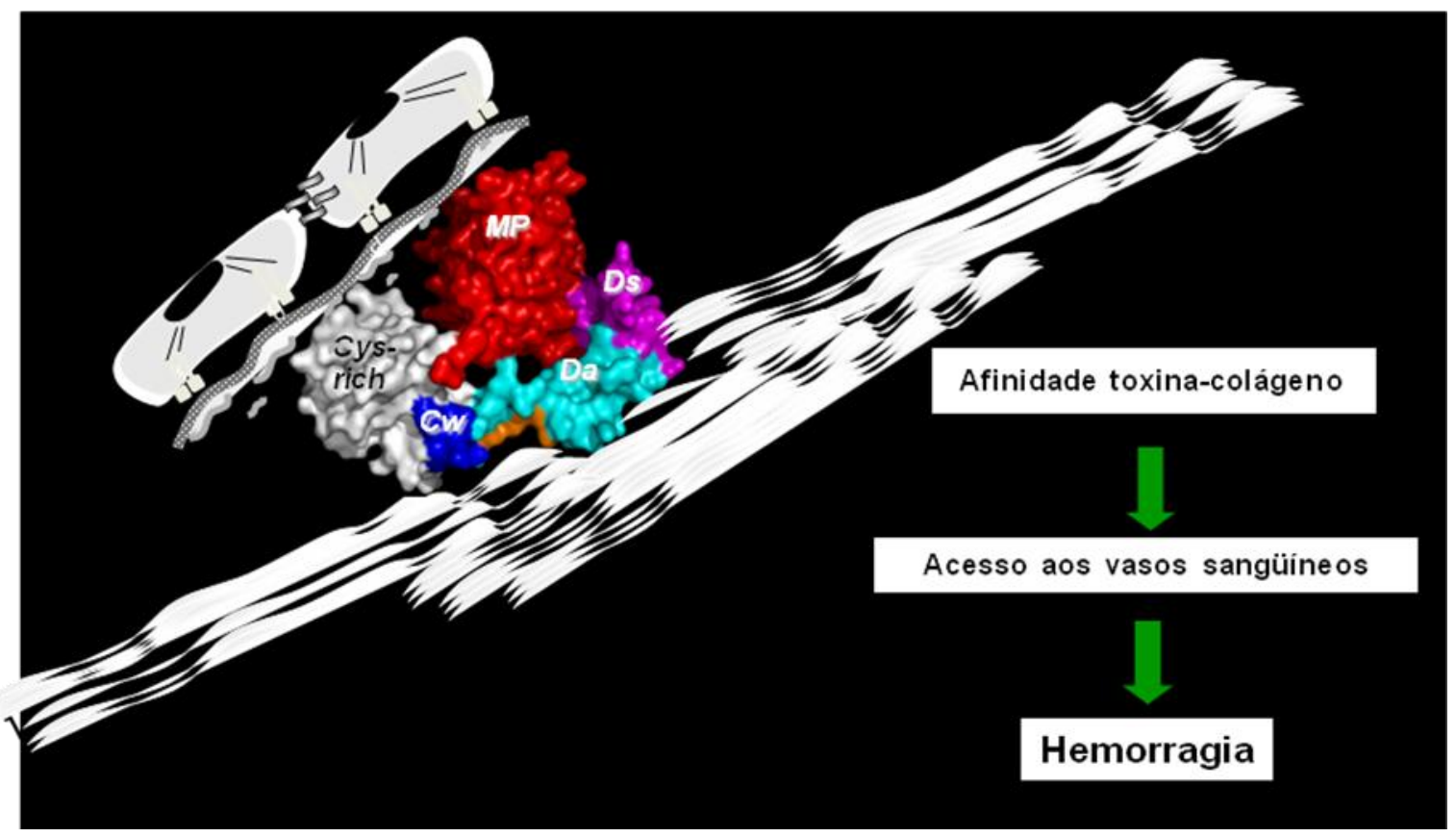

Figura 32- Mecanismo de indução da atividade hemorrágica pelas SVMPs da classe P-III. A afinidade de toxinas das classes P-III ao colágeno promove seu acúmulo nas proximidades dos vasos sangüíneos tornando a catálise dos componentes da membrana basal vascular mais eficiente, resultando na forte hemorragia local induzida pelas SVMPs hemorrágicas. 


\section{CONCLUSÕES}

- A BnP1 possui ação similar à jararagina em relação à proteólise de componentes plasmáticos e de matriz extracelular e ação em células endoteliais, mas a ligação ao colágeno foi detectada apenas para a jararagina e para a jararagina-C.

- A jararagina, mas não a BnP1, se acumula próxima aos vasos sangüíneos, e co-localiza-se com o colágeno IV presente na membrana basal vascular.

- A hemorragia induzida pela jararagina concentrou-se na hipoderme onde ocorreu a degradação do colágeno fibrilar. Nas membranas basais observou-se preferencialmente a clivagem do colágeno tipo IV.

- Os resultados descritos neste trabalho suportam a hipótese de que a ligação ao colágeno promove o acúmulo das SVMPs hemorrágicas nas proximidades dos vasos sangüíneos resultando na evidente hemorragia local induzida pelas SVMPs da classe P-III.

- Esses dados explicam, pela primeira vez na literatura, o motivo pelo qual toxinas com atividade catalítica semelhante e mesma ação em células endoteliais, diferem quanto à atividade hemorrágica 


\section{REFERÊNCIAS BIBLIOGRÁFICAS ${ }^{1}$}

ADLER, M.; LAZARUS, R. A.; DENNIS, M. S.; WAGNER, G. Solution structure of kistrin, a potent platelet aggregation inhibitor and GP IIb-IIIa antagonist. Science, v. 253, p. 445-448, 1991.

ALTSCHUL, S. F.; MADDEN, T. L.; SCHAFFER, A. A.; ZHANG, J.; ZHANG, Z.; MILLER, W.; LIPMAN, D.J. Gapped BLAST and PSI-BLAST: a new generation of protein database search programs. Nucleic Acids Res., v. 25, p. 3389-3402, 1997.

ASSAKURA, M. T.; SILVA, C. A.; MENTELE, R.; CAMARGO A. C.; SERRANO S. M. Molecular cloning and expression of structural domains of bothropasin, a P-III metalloproteinase from the venom of Bothrops jararaca. Toxicon, v. 41, p. 217-227, 2003.

BALDO, C.; TANJONI, I.; LEON, I. R.; BATISTA, I. F.; DELLA-CASA, M. S.; CLISSA P. B.; WEINLICH, R.; LOPES-FERRREIRA, M.; LEBRUN, I.; AMARANTES-MENDES, G. P.; RODRIGUES, V. M.; PERALES J.; VALENTE, R. H.; MOURA-DA-SILVA, A. M. BnP1, a novel P-I metalloproteinase from Bothrops neuwiedi venom: biological effects benchmarking relatively to jararhagin, a P-III SVMP. Toxicon, v. 51, p. 54-65, 2008.

BARRAMOVA, E. N.; SHANNON, J. D.; BJARNASON, J. B.; FOX, J. W. Degradation of extracellular matrix proteins by hemorrhagic metalloproteinases, Arch. Biochem. Biophy., v. 275, p. 63-71, 1989.

BARRAMOVA, E. N.; SHANNON, J. D.; BJARNASON, J. B.; GONIAS, S. L.; FOX, J. W. Interaction of hemorrhagic metalloproteinases with human alpha 2-macroglobulin. Biochesmistry, v. 29, p. 1069-1074, 1990.

BERRIER, A. L.; YAMADA, K. M. Cell-matrix adhesion. J. Cell. Physiol., v. 213, p. 565573, 2007.

BJARNASON, J .B.; FOX J. W. Hemorrhagic toxins from snake venoms. Pharmacol. Ther., v. 62, p. 325-372, 1994. Review.

BJARNASON, J. B.; HAMILTON, D.; FOX, J. W. Studies on the mechanism of hemorrhage production by five proteolytic hemorrhagic toxins from Crotalus atrox venom. Biol. Chem., v. 369, p. 121-129, 1988.

BODE, W; GOMIS-RUTH, F.; STOCKER, W. Astacins, serralysins, snake venom and matrix metalloproteinases exhibit identical zinc-binding environments (HEXXHXXGXXH and met-turn) and topologies and should be grouped into a common family, the metzcins. FESB Lett., v. 331, p.134-140, 1993.

\footnotetext{
${ }^{1}$ De acordo com:

ASSOCIAÇÃO BRASILEIRA DE NORMAS TÉCNICAS. NBR 6023: Informação e documentação: referências: elaboração. Rio de Janeiro, 2002.
} 
BRESSLER, R. S.; BRESSLER, C. H. Functional anatomy of the skin. Clin. Pediatr. Med. Surg., v. 6, p. 229-246, 1989.

CALVETE, J. J.; MARCINKIEWICZ, C.; MONLEON, D.; ESTEVE, V.; CELDA, B.; JUAREZ. P.; SANZ, L. Snake venom disintegrins: evolution of structure and function. Toxicon, v. 45, p. 1063-1074, 2005. Review.

CANTY, E. G.; KADLER, K. E. Procollagen trafficking, processing and fibrillogenesis. J. Cell. Sci., v. 118, p.1341-1353.

CARDOSO, J. L. C.; FAN, H. W.; FRANÇA, F. O. S.; JORGE, M. T.; LEITE, R. P.; NISHIOKA, S. A,; AVILA, A., SANO-MARTINS, L. S.; TOMY, S. C.; SANTORO, M. L., CHUDZINSKY, A. M; CASTRO, S. C. B.; KAMIGUTI, A. S.; KELEN, E. M. A.; HIRATA, M. H.; MIRANDOLA, R. M. S.; THEAKSTON, R. D. G.; WARRELL, D. A. Randomized comparative Trial of three antivenoms in the treatment of envenoming by lance-headed vipers (Bothrops jararaca) in Sao Paulo, Brazil. Q. J. Med., v. 86, p. 315-325, 1993.

CHEN, R. Q.; JIN, Y.; WU, J. B.; ZHOU, X. D.; LU, Q. M.; WAND, W. Y.; XIONG, Y. L. A new protein structure of P-II class snake venom metalloproteinase comprises metalloproteinase and disintegrin domains. Biochem. Biophys. Res. Commun., v. 310 p. 182-87, 2003.

CHING, A. T.; ROCHA, M. M.; PAES LEME, A. F.; PIMENTA, D. C.; DE FÁTIMA D. FURTADO, M.;, SERRANO, S. M.; HO, P. L.; JUNQUEIRA-DE-AZEVEDO, I. L. Some aspects of the venom proteome of the Colubridae snake Philodryas olfersii revealed from a Duvernoy's (venom) gland transcriptome. FEBS Lett., v. 7, p. 4417-4422.

CHIPPAUX, J. P.; WILLIAMS, V.; WHITE, J. Snake venom variability: methods of study, results and interpretation. Toxicon, v. 29, p. 1279-1303, 1991.

CLISSA, P. B.; LAING, G. D.; THEAKSTON, R. D. G.; MOTA, I.; TAYLOR, M. J.; MOURA-DA-SILVA, A. M.; The effect of jararhagin, a metalloproteinase from Bothrops jararaca venom, on pro-inflammatory cytokines released by murine peritoneal adherents cells. Toxicon, v. 39, p. 1567-1573, 2001.

CLISSA, P. B.; LOPES-FERREIRA, M.; DELLA-CASA, M. E.; FARSKY, S. H. P.; MOURA-DA-SILVA, A. M. Importance of jararhagin disintegrin-like and cysteine-rich domains in the early events of local inflammatory response. Toxicon, v. 47, p.591-596, 2006.

COMBET, C.; BLANCHET, C.; GEOURJON, C.; DELEAGE, G. NPS@: Network Protein Sequence analysis. Trends Biochem. Sci., v. 25, p. 147-150, 2000.

COMINETTI, M. R.; TERRUGGI, C. H.; RAMOS, O. H.; FOX, J. W.; MARIANOOLIVEIRA, A.; DE FREITAS, MS.; FIGUEIREDO, C. C.; MORANDI, V.; SELISTRE-DEARAUJO, H. S. Alternagin-C, a disintegrin-like protein, induces vascular endothelial cell growth factor (VEGF) expression and endothelial cell proliferation in vitro. J. Biol. Chem., v. 279 , p. $18247-55,2004$. 
COMINETTI, M. R.; RIBEIRO, J. U.; FOX, J. W.; SELISTRE-DE-ARAUJO, H. S. BaG, a new dimeric metalloproteinase-disintegrin from the Bothrops alternatus snake venom that interacts with $\alpha_{5} \beta_{1}$ integrin. Arch. Biochem. Biophys., v. 416, p. 171-179, 2003.

COSTA, E. P.; CLISSA, P.B.; TEIXEIRA, C. F. P.; MOURA-DA-SILVA, A. M. Importance of metalloproteinases and macrophages in viper snake envenomation-induced local inflammation. Inflammation, v. 26, p. 13-17, 2002.

DALE, S.; GONÇALVES, L. R. C.; JULIANO, L.; JULIANO, M. A.; MOURA-DA SILVA, A. M.; GIORGI, R. The C-terminus of murine S100A9 inhibits hyperalgesia and edema induced by jararhagin. Peptides, v. 25, p. 81-89, 2004.

DE LUCA, M.; WARD, C. M.; OHMORI, K.; ANDREWS, R. K.; BERNDT, M. C. Jararhagin and jaracetin: novel snake venom inhibitors of the integrin collagen receptor, $\alpha_{2} \beta_{1}$, Biochem. Biophys. Res. Commun., v. 206, p. 570-576, 1995.

DE MORAES, C. K.; SELISTRE-DE-ARAÚJO, H. S. Effect of rACLF, a recombinat snake venom metallopeptidase on cell viability, chemokine expression and degradation of extracellular matrix proteins. Toxicon, v. 48, p. 641-648, 2006.

DÍAZ, C.; VALVERDE, L.; BRENES, O.; RUCAVADO, A.; GUTIÉRREZ, J. M. Characterization of events associated with apoptosis/anoikis induced by snake venom metalloproteinase BaP1 on human endothelial cells. J. Cell Biochem., v. 94, p. 520-528 2005.

EDMAN, P.; BEGG, G. A protein sequenator, Eur. J. Biochem., v. 1, p. 80-91, 1967.

SELISTRE-DE-ARAUJO, H. S.; COMINETTI, M. R.; TERRUGGI, C. H.; MARIANOOLIVEIRA, A.; DE FREITAS, M. S.; CREPIN， M.; FIGUEIREDO， C. C.; MORANDI $\mathrm{V}$. Alternagin-C, a disintegrin-like protein from the venom of Bothrops alternatus, modulates alpha2beta1 integrin-mediated cell adhesion, migration and proliferation. Braz. J. Med. Biol. Res., v. 38, v. 1505-1511, 2005.

ESCALANTE, T.; NUÑEZ, J.; MOURA-DA-SILVA, A.M.; RUCAVADO, A.; THEAKSTON, R.G.D.; GUTIÉRREZ, J.M. Pulmonary hemorrhage induced by jararhagin, a metalloproteinase from Bothrops jararaca snake venom. Toxicol. Appl. Pharmacol., v. 193, p.17-28, 2003.

ESCALANTE, T.; SHANNON, J.; MOURA-DA-SILVA, A. M.; GUTIERREZ, J. M.; FOX, J. W. Novel insights into capillary vessel basement membrane damage by snake venom hemorrhagic metalloproteinases: a biochemical and immunohistochemical study. Arch. Biochem. Biophys., v.15, p.144-153. 2006.

ESTEVÃO-COSTA, M. I.; DINIZ, C. R.; MAGAlHAES, A.; MARKLAND, F. S.; SÁNCHEZ, E. F. Action of metalloproteinases mutalysin I and III on several components of the hemostatic and fibrinolytic systems. Thromb. Res., v. 99, p. 363-376. 
FERNANDES, C. M.; ZAMUNER, S. R.; ZULIANI, P. J.; RUCAVADO, A.; GUTIÉRREZ, J. M.; TEIXEIRA, C. F. Inflammatory effects of BaP1 a metalloproteinase isolated from Bothrops asper snake venom: Leukocyte recruitment and release of cytokines. Toxicon, v. 47, p. 549-559, 2006.

FOWLKES, J. L.; WINKLER, M. K. Exploring the interface between metallo-proteinase activity and growth factor and cytokines bioavailability. Cytokine Growth Factor Rev., v. 13, p. 277-287, 2002. Review.

FOX, J. W.; SERRANO, S. M. T. Insights into and speculations about snake venom metalloproteinase (SVMP) synthesis, folding and disulfide bond formation and their contribution to venom complexity. FEBS J., v. 275, p.3016-3030, 2008. Review.

FRANÇA, F. O. S.; MÁLAQUE, C. M. S. Acidente botrópico. In: CARDOSO, J. L. C.; FRANÇA, F. O. S.; WEN, F. H.; MÁLQUE, C. M. S.; HADDAD JR, V. (Ed.). Animais peçonhentos no Brasil, Biologia, Clínica e Terapêutica. São Paulo: Editora Sarvier, 2003. p. $72-86$.

FRANK, S.; KAMMERER, R. A.; MECHLING, D.; SCHULTHESS, T.; LANDWEHR, R.; BANN, J.; GUO, Y.; LUSTIG, A.; BAĖCHINGER H. P.; ENGEL, J. Stabilization of Short Collagen-like Triple Helices by Protein Engineering. J. Mol. Biol., v. 308, 1081-1089.

GALLAGHER, P.; BAO, Y.; SERRANO, S. M. T.; LAING, G. D.; THEAKSTON, R. D. G.; MAUCH, C.; MOSKALUK, C.; FOX, J. W. Role of the snake venom toxin jararhagin in proinflammatory pathogenesis: In vitro and in vivo gene expression analysis of the effects of the toxin. Arch. Biochem. Biophy., v. 45, p.1-15,2005.

GUO, X. X.; ZENG, L.; LEE, W. H.; ZHANG, Y.; JIN, Y. Isolation and cloning of a metalloproteinase from king cobra snake venom. Toxicon, v. 49, p. 954-965, 2007.

GUTIERREZ J. M.; RUCAVADO A. Snake venom metalloproteinases: Their role the pathogenesis of local tissue damage. Biochimie, v. 82, p.841-850, 2000. Review.

GUTIERREZ, J. M.; RUCAVADO, A.; ESCALANTE, T.; DÍAZ, C. Hemorrhage induced by snake venom metalloproteinases: biochemical and biophysical mechanisms involved in microvessel damage. Toxicon, v. 45, p. 997-1011, 2005. Review.

GUTIERREZ J. M.; LOMONTE B.; LÉON G.; RUCAVADO A.; CHAVES, F.; YAMILETH, A. Trends in snakebite therapy: scientific. Technological and public health considerations. Curr. Pharm. Desig., v. 13, p. 1-16, 2007. Review.

HAMAKO, J.; MATSUI, T.; NISHIDA, S.; NOMURA, S.; FUJIMURA, Y.; ITO, M.; OZEKI, Y.; TITANI, K.. Purification and characterization of kauthiagin, a von Willebrand factor-binding and -cleaving metalloproteinase from Naja Kaouthia cobra venom. Thromb. Haemost., v. 80, p. 499-505, 1998.

HATI, R.; MITRA, P.; SARKER, S.; BHATTACHARYYA, K. K. Snake venom hemorrhagins. Crit. Rev. Toxicol., v. 29, p. 1-19,1999. Review. 
HOHENESTER, E.; ENGEL, J.; Domain structure and organisation in extracellular matrix proteins. Matrix Biol., v. 21, p. 115-128, 2002. Review.

HOOPER, N. M. Families of zinc metalloproteases. FESB Lett., v. 354, p.1-6, 1994. Review.

HUANG, T. F.; CHANG, M. C.; TENG, C. M. Antiplatelet protease, kistomin, selectively cleaves human platelet glycoprotein Ib. Biochim. Biophys Acta, v. 1158, p. 293-299, 1993.

HUMPHRIES, J.D.; BYRON, A.; HUMPHRIES, M. J. Integrin ligands at a glance. J. Cell Sci., v. 119, p. 3901-3903, 2006. Review.

IVASKA, J.; KÄPYLÄ, J.; PENTIKÄINEN, O.; HOFFREN, A. M.; HERMONEN, J.; HUTTUNEN, P.; JOHNSON, M. S.; HEINO, J. A peptide inhibiting the collagen binding function of $\alpha_{2} \beta_{1}$ integrin. J. Biol. Chem., v. 274, p. 3513-3521, 1999.

JESPERSEN, J.; ASTRUP, T. A study of the fibrin plate assay of fibrinolytic agents: Optimal conditions, reproducibility and precision. Haemostasis, v. 13, p. 301-315, 1983.

JIA, L. G.; WANG, X. M.; SHANNON, J. D.; BJARNASON, J. B.; FOX, J. W. Function of disintegrin-like/cysteine-rich domains of atrolysin-A. Inhibition of platelet aggregation by recombinant protein and peptide antagonists. J. Biol. Chem., v. 272, 13094-13102, 1997.

JIMÉNEZ, N.; ESCALANTE, T.; GUTIÉRREZ, J. M.; RUCAVADO, A. Skin pathology induced by snake venom metalloproteinase: acute damage, revascularization, and reepithelization in a mouse ear model. J. Invest. Dermatol., v. 128, p. 2421-2428, 2008.

JUNQUEIRA-DE-AZEVEDO, I. L.; HO, P. L. A survey of gene expression and diversity in the venom glands of the pitviper snake Bothrops insularis through the generation of expressed sequence tags (ESTs). Gene, v. 299, p. 279-291, 2002.

KALLURI, R. Basement membranes: structure, assembly and role in tumour angiogenesis. Nat. Rev. Cancer, v. 3, p. 422-433, 2003. Review.

KAMIGUTI, A. S.; SLUPSKY, J. R.; ZUZEL, M.; HAY, C. R. Properties of fibrinogen cleaved by jararhagin, a metalloproteinase from the venom of Bothrops jararaca. Thromb. Haemost., v. 72, p. 244-249, 1994a.

KAMIGUTI, A. S.; DESMOND, H. P.; THEAKSTON, R .D. G.; HAY, C. R. M.; ZUZEL, $M$. Ineffectiveness of the inhibition of the main haemorrhagic metalloproteinase from Bothrops jararaca venom by its only plasma inhibitor, $\alpha 2$-macroglobulin. Biochem. Biophys. Acta, v. 1200, p. 307-314, 1994b.

KAMIGUTI, A. S.; HAY, C. R. M.; THEAKSTON, R. D. G.; ZUZEL, M. Insights into the mechanism of haemorrhage caused by snake venom metalloproteinases, Toxicon, v. 34, p. 627-642,1996a. Review.

KAMIGUTI, A. S.; HAY, C. R. M.; ZUZEL, M. Inhibition of collagen-induced platelet aggregation as the result of cleavage of $\alpha_{2} \beta_{1}$-integrin by the snake venom metalloproteinase jarararhagin. Biochem. J., v. 320, p. 635-641,1996b. 
KAMIGUTI, A.S.; MARKLAND, F.S.; ZHOU, Q.; LAING, G.D.; THEAKSTON, R.D.G.; ZUZEL, M. Proteolytic cleavage of the beta 1 subunit of platelet $\alpha_{2} \beta_{1}$-integrin by the metalloproteinase jararhagin compromises collagen-stimulated phosphorylation of pp72. J. Biol. Chem., v. 272, p. 32599-32605, 1997.

KAMIGUTI, A. S.; GALLAGER, P.; MARCINKIEWICZ, C.; THEAKSTON, R. G. D.; ZUZEL, M.; FOX, J. W. Identification of sites in the cysteine-rich domain of the class P-III snake venom metalloproteinase responsible for the inhibition of platelet function. FEBS Lett., v. 549, p.129-134, 2003.

KAMIGUTI, A. S. Platelets as targets of snake venom metalloproteinases. Toxicon, v. 45, p.1042-1049, 2005. Review.

KONDO, H.; KONDO, S.; IKEZAWA, H.; MURATA, R.; OHSAKA, A. Studies on the quantitative method for determination of hemorrhagic activity of habu snake venom. Jpn. J. Med. Sci. Biol., v.13, p. 43-51, 1960.

LAEMMLI, U. K. Cleavage of structural proteins during the assembly of the head of bacteriophage T4. Nature, v. 227, p. 680-685, 1970.

LAING, G.D.; CLISSA, P. B.; THEAKSTON, R. D. G.; MOURA-DA-SILVA, A. M.; TAYLOR, M. J. Inflammatory pathogenesis of snake venom metalloproteinases-induced skin necrosis. Eur. J. Immunol., v. 33, p. 3458-3463, 2003.

LAYNE, E. Spectrophotometric and turbidimetiric methods for measuring proteins. Methods Enzymol., v. 3, p. 44-454, 1957.

LEBLEU, V. S.; MACDONALD, B.; KALLURI, R. Structure and function of basement membranes. Exp. Biol. Med., v. 232, p. 1121-1129, 2007.

LEITINGER, B.; HOHENESTER, E. Mammalian collagen receptors. Matrix Biol., v. 26, p. 146-155, 2007. Review.

LIU, C.; HUANG, T. Crovidisin, a collagen-binding protein isolated from snake venom of Crotalus viridis, prevents platelet-collagen interaction. Arch. Biochem. Biophys., v. 2, p. 291-299, 1997.

LOMONTE, B.; GUTIÉRREZ, J. M.; BORKOW, G.; OVADIA, M.; TARKOWSKI, A.; HANSON, L. A. Activity of hemorrhagic metalloproteinase BaH-1 and myotoxin II from Bothrops asper snake venom on capillary endothelial cells in vitro. Toxicon, v. 32, p. 505510.

LOPES, D. S.; BALDO, C.; OLIVEIRA, C. F; MACHADO DE ALCÂNTARA, T.; DIAS OLIVEIRA, J. D.; GOURLART, L. R.; HAMAGUCHI, A.; HOMSI-BRANDEBURGO, M. I.; MOURA-DA-SILVA, A. M.; CLISSA, P. B.; RODRIGUES, V. M. Characterization of inflammatory reaction induced by neuwiedase, a P-I metalloproteinase isolated from Bothrops neuwiedi venom. Toxicon, 2009. In press. 
LU, Q.; NAVDAEV, A.; CLEMETSON, J. M.; CLEMETSON， K. J. Snake venom C-type lectins interacting with platelets receptors. Structure-function relationships and effects on haemostasis. Toxicon, v. 45, p. 1089-1098. 2005. Review.

LUO, B. H.; CARMAN, C. V.; SPRINGER, T. Structural basis of integrin regulation and signaling. Ann. Rev. Immunol., v. 25, p. 619-647, 2007.

MARCUSSI, S.; BERNARDES, C. P.; SANTOS-FILHO, N. A.; MAZZI, M. V.; OLIVEIRA, C. Z.; IZIDORO, L. F.; FULY, A. L.; MAGRO, A. J.; BRAZ, A. S.; FONTES, M. R.; GIGLIO, J. R.; SOARES, A. M. Molecular and functional characterization of a new non-hemorrhagic metalloprotease from Bothrops jararacussu snake venom with antiplatelet activity. Peptides, v. 28, p. 2328-2339, 2007.

MARKLAND, F. S. Snake venoms and the hemostatic system. Toxicon, v. 36, p. 1749-1998, 1998. Review.

MARUYAMA, M.; SUGIKI, M.; YOSHIDA, E.; SHIMAYA K.; MIHARA, H. Broad substrate specificity of snake venom fibrinolytic enzymes: possible role in hemorrhage. Toxicon, v. 30, p. 1387-1397, 1992.

MASUDA, S.; HAYASHI, H.; ATODA, H.; MORITA, T.; ARAKI, S. Purification, cDNA cloning and characterization of the vascular apoptosis-inducing protein, HV1, from Trimeresurus flavoviridis. Eur. J. Biochem. v. 268, p. 3339-3345, 2001.

MATSUI, T.; FUJIMURA, Y.; TITANI, K. Snake venom proteases affecting hemostasis and thrombosis. Biochim. Biophys. Acta, v. 1477, p. 146-156, 2000.

MCKAY, D. G.; MOROZ, C.; DEVRIES, A.; CSAVOSSY, I.; CRUSE, V. The action of hemorrhagin and phospholipase derived from Vipera palestinae venom on the microcirculation. Lab. Invest., v. 22, p.387-399, 1970.

MODESTO, J. C.; JUNQUEIRA-DE-AZEVEDO, I. L. M.; NEVES-FERREIRA, A. G. C.; FRITZEN, M.; OLIVA, M. L. V.; HO, P. L.; PERALES, J.; CHUDZINSKI-TAVASSI, A. M. Insularinase A, a prothrombin activator from Bothrops insularis venom, is a metalloprotease derived from a gene encoding protease and disintegrin domains. Biol. Chem., v. 386, p.586-600, 2005.

MONTES, G. S.; JUNQUEIRA, L. C. The use of the Picrosirius-polaization method for the study of the biopathology of collagen. Mem. Inst. Oswaldo Cruz, v. 86, 1-11, 1991.

MOURA-DA-SILVA, A. M.; LAING, G. D.; PAINE, M. J. I.; DENNISON, J. M. T. V.; POLITI, V.; CRAMPTON, J. M.; THEAKSTON, R. D. G. Processing of pro-tumor necrosis factor- $\alpha$ by venom metalloproteinases: a hypothesis explaining local tissue damage following snake bite. Eur. J. Immunol., v. 26, p. 2000-2005, 1996a.

MOURA-DA-SILVA, A. M.; THEAKSTON, R. G. D.; CRAMPTON, J. M. Evolution of disintegrin cystein-rich and mammalian matrix-degrading metalloproteinases: gene duplication and divergence of a common ancestor rather than convergent evolution. J. Mol. Evol., v. 43, p. 263-269, 1996b 
MOURA-DA-SILVA, A. M.; LÍNICA, A.; DELLA-CASA, M. S.; KAMIGUTI, A. S.; HO, P. L.; CRAMPTON, J. M.; THEAKSTON, R. D. G. Jararhagin ECD-Containing Disintegrin Domain: Expression in Escherichia coli and Inhibition of the Platelet-Collagen Interaction. Arch. Biochem. Biophys., v. 369, p. 295-301, 1999.

MOURA-DA-SILVA, A. M.; MARCINKIEWICZ, C.; MARCINKIEWICZ, M.; NIEWIAROWSKI, S. Selective recognition of $\alpha_{2} \beta_{1}$ integrin by jararhagin, a metalloproteinase/disintegrin-like from Bothrops jararaca venom. Thromb. Res., v. 102, p.153-159, 2001.

MOURA-DA-SILVA, A. M.; DELLA-CASA, M. S.; DAVID, A. S.; ASSAKURA, M. T.; BUTERA, D.; LEBRUN, I.; SHANNON, J. D.; SERRANO, S. M. T.; FOX, J. W. Evidence for heterogeneous forms of the snake venom metalloproteinase jararhagin: a factor contributing to snake venom variability. Arch. Biochem. Biophys., v. 490, p. 395-401, 2003.

MOURA-DA-SILVA, A. M.; BUTERA, D.; TANJONI, I. Importance of snake venom metalloproteinases in cell biology: Effects on platelets, inflammatory and endothelial cells. Curr. Pharm. Des., v. 13, 2893-26905, 2007. Review.

MOURA-DA-SIVA, A. M.; RAMOS, O. H. P.; BALDO, C.; NILAND, S.; HANSEN, U.; VENTURA, J. S.; FURLAN, S.; BUTERA, D.; DELLA-CASA, M. S.; TANJONI, I.; CLISSA, P. B.; FERNANDES, I.; CHUDZINSKI-TAVASSI, A. M.; EBLE, J. A. Collagen binding is a key factor for the hemorrhagic activity of snake venom metalloproteinases. Biochimie, v. 90, p. 484-492, 2008.

MYLLYHARJU, J.; KIVIRIKKO, K. I. Collagens, modifying enzymes and their mutations in humans, files and worms. Trends Genet., v. 20, p. 33-43, 2004. Review.

NICOLlETI, I.; MIGLIORATI, G.; PAGLIACCI, M. C.; GRIDNANI, F.; RICCARDI, C. A rapid and simple method for measuring thymocyte apoptosis by propidium iodide staining and flow cytometry. J. Immunol. Methods, v. 139, p. 271-279, 1991.

NIEWIAROWSKI, S.; MCLANE, M. A.; KLOCZEWIAK, M.; STEWART, G. J. Disintegrins and other naturally occurring antagonists of platelet fibrinogen receptors. Semin. Hematol., v. 31, p. 289-300, 1994.

OHSAKA, A.; OHASHI, M.; TSUCHIYA, M.; KAMISAKA, Y.; FUJISHIRO, Y. Action of Trimeresurus flavoviridis venom on the microcirculatory system of rat: Dynamic aspects as revealed by cinephotomicrographic recording. Jpn. J. Med. Sci. Biol., v. 24, p. 34-39, 1971.

OHSAKA, A.; JUST, M.; HABERMANN, E. Action of snake venom hemorrhagic principles on isolated glomerular basement membrane. Biochim. Biophys. Acta, v. 323, p. 415-428, 1973. 
OTERO, R.; GUTIERREZ, J. M.; MESA, M.B.; DUQUE, E.; RODRIGUES, O.; ARANGO, J. L.; GOMES, F.; TORO, A., CANO, F.; RODRIGUES, L. M.; CARO, E.; MARTINEZ, J.; CORNEJO, W.; GOMEZ, L. M.; URIBE, F. L.; CARDENAS, S.; NUNEZ, V.; DIAS. Complications of Bothrops, Porthidium, and Bothriechis snakebites in Colombia. A clinical and epidemiological study of 39 cases attended in a university hospital. Toxicon, v. 40, p. 1107-1114, 2002.

OWNBY, C. L.; BJARNASON, J. B.; TU, A. T. Hemorrhagic toxins from rattlesnake (Crotalus atrox) venom. Pathogenesis of hemorrhage induced by three purified toxins. Am. J. Pathol., v. 93, p. 201-218, 1978.

PAINE, M. J. I.; DESMOND, H. P.; THEAKSTON, R. D. G.; CRAMTON, J. M. Purification, cloning, and molecular characterization of a high molecular weight hemorrhagic metalloprotease, jarahagin, from Bothrops jararaca venom. J. Biol. Chem., v. 267, p. 2286922876, 1992.

PAUlinO, F. E. C.; MAGAlHÃES, M. R.; SILVA, N. J. Atualização da distribuição geográfica de serpentes do gênero Bothrops dos Estados de Goiás, Tocantins e Distrito Federal. In: CONGRESSO BRASILEIRO DE ZOOLOGIA, 18., 1991, Salvador. Abstract...: Salvador: Congresso Brasileiro de Zoologia, 1991. p. 334.

RIBEIRO, L. A.; JORGE, M. T. Acidentes por serpentes do gênero Bothrops: série de 3.139 casos. Rev. Soc. Brás. Med. Trop., v. 30, p.475-480, 1997.

RODRIGUES, V. M.; SOARES, A. M.; GUERRA-SÁ, R.; RODRIGUES, V.; FONTES, M.R.; GIGLIO, J. R. Structural and functional characterization of neuwiedase, a nonhemorrhagic fibrin(ogen)olytic metalloprotease from Bothrops neuwiedi snake venom. Arch. Biochem. Biophys., v. 381, p. 213-224, 2000.

RODRIGUES, V. M.; SOARES, A. M.; ANDRIÃO-ESCARSO, S. H.; FRANCESCHI, A. M.; RUCAVADO, A.; GUTIERREZ, J. M.; GIGLIO J. R. Pathological alterations induced by neuwiedase, a metalloproteinase isolated from Bothrops neuwiedi snake venom. Biochemie, v. 83, p. 471-479, 2001.

RUCAVADO, A.; LOMONTE, B.; OVADIA, A.; GUTIÉRREZ, J. M. Local tissue damage induced by BaP-I, a metalloproteinase isolated from Bothrops asper (terciopelo) snake venom. Exp. Mol. Pathol., v. 63, 186-199, 1995.

RUCAVADO, A.; NÚNEZ, J.; GUTIÉRREZ, J. M. Blister formation and skin damage induced by BaP1, a hemorrhagic metalloproteinase from the venom of the snake Bothrops asper. Int. J. Exp. Pathol., v. 79, p. 245-54, 1998.

RUCAVADO, A.; FLORES-SANCHES, E.; FRANCESHI, A.;MAGALHAES, A.; GUTIRREZ, J. M. Characterization of the local tissue damage induced by LHF-II, a metalloproteinase with weak hemorrhagic activity isolated from Lachesis muta muta snake venom. Toxicon, v. 37, p. 1297-1312, 1999. 
RUCAVADO, A.; ESCALANTE, T.; TEIXEIRA, C. F. P.; FERNANDES, C. M.; DIAZ, C.; GUTIERREZ, J. M. Increments in cytokines and matrix metalloproteinases in skeletal muscle after injection of tissue-damaging toxins from the venom of the snake Bothrops asper. Mediators Inflamm., v. 11, p.121-128, 2002.

SAUDEK, V.; ATKINSON, R. A; PELTON, J. T. Three-dimensional structure of echistatin, the smallest active RGD protein. Biochemistry, v. 30, p. 7369-7372, 1991.

SCHATTNER, M.; FRITZEN, M.; VENTURA, J. S.; MODESTO, J. C. A.; POZNER, R. G.; MOURA-DA-SILVA, A. M.; CHUDZINSKI-TAVASSI, A. M. The snake venom metalloproteases berythractivase and jararhagin activate endothelial cells. Biol. Chem., v. 386, p.369-374, 2005.

SELISTRE-DE-ARAUJO, H. S.; COMINETTI M. R.; TERRUGGI, C. H.; MARIANOOLIVEIRA, A.; DE FREITAS, M. S.; CREPIN, M.; FIGUEIREDO, C. C.; MORANDI, V. Alternagin-C, a disintegrin-like protein from the venom of Bothrops alternatus, modulates alpha2beta1 integrin-mediated cell adhesion, migration and proliferation. Braz. J. Med. Biol. Res., v. 38, p. 1505-1511, 2005.

SERRANO, S. M. T.; JIA, L. G.; WANG, D.; SHANNON, J. D.; FOX, J. W. Function of the cysteine-rich domain of the hemorrhagic metalloproteinase atrolysin-A: targeting adhesion proteins collagen I and von Willebrand factor. Biochem. J., v. 391, p. 69-76, 2005.

SERRANO, S. M. T.; KIM, J.; WANG, D.; DRAGULEV, B.; SHANNON, J. D.; MANN, H. H.; VEIT, G.; WAGENER, R.; KOCH, M.; FOX, J. W. The cysteine-rich domain of snake venom metalloproteinases is a ligand for von Willebrand factor A domains: role in substrate targeting. J. Biol. Chem., v. 281, p. 39746-39756, 2006.

SHEVCHENKO, A.; WILM, M.; VORM, O.; MANN, M. Mass spectrometric sequencing of proteins silver-stained polyacrylamide gels. Anal. Chem., v. 68, p. 850-858, 1996.

SILVA, M. B.; SCHATTNER, M.; RAMOS, C. R.; JUNQUEIRA-DE-AZEVEDO, I. L.; GUARNIERI, M. C.; LAZZARI, M. A.; SAMPAIO, C. A.; POZNER, R. G.; VENTURA, J. S.; HO, P. L.; CHUDZINSKI-TAVASSI, A. M. A prothrombin activator from Bothrops erythromelas (jararaca-da-seca) snake venom: characterization and molecular cloning, Biochem. J., v. 369, p. 129-139, 2003.

SOUZA, D. H.; IEMMA, M. R.; FERREIRA, L. L.; FARIA, J. P.; OLIVA, M. L.; ZINGALI, R. B.; NIEWIAROWSKI, S.; SELISTRE-DE-ARAUJO, H. S. The disintegrinlike domain of the snake venom metalloprotease alternagin inhibits alpha2beta1 integrinmediated cell adhesion. Arch. Biochem. Biophys., v. 384, p.341-450, 2000.

STOCKER, W.; BODE, W. Structural features of a superfamily of zinc-endopeptidases: the metzincins. Cur. Opin. Struct. Biol., v. 5, p. 383-390, 1995.

SWENSON, S.; MARKLAND JR, F. S. Snake venom fibrin(ogen)olytic enzymes. Toxicon, v. 45, p. 1-19, 2005. Review. 
TAKEYA, H.; ODA, K.; MIYATA, T.;OMORI-SATOH, T.; IWANAGA, S. The complete amino acid sequence of the high molecular mass hemorrhagic protein HR1B isolated from the venom of Trimeresurus flavoviridis. J. Biol. Chem., v. 265, p. 16068-16073, 1990.

TANJONI, I.; BUTERA, D.; BENTO, L.; DELLA-CASA, M. E.; MARQUES-PORTO, R.; TAKEHARA, H. A.; GUTIERREZ, J. M.; FERNANDES, I.; MOURA-DA-SILVA, A. M. Snake venom metalloproteinases: structure/function relationships studies using monoclonal antibodies. Toxicon, v. 42, p. 801-808, 2003.

TANJONI, I.; WEINLICH, R.; DELLA CASA, M. S.; CLISSA, P. B.; SALDANHA-GAMA, R. F.; FREITAS, M. S.; BARJA-FIDALGO, C.; AMARANTE-MENDES, G. P.; MOURADA-SILVA, A. M. Jararhagin, a snake venom toxin, induces a specialized form of apoptosis (anoikis) selective to endothelial cells. Apoptosis, v. 10, p. 851-861, 2005.

TRUMMAL, K.; TONISMAGI, K.; SIIGUR, E.; AASPOLLU, A.; LOPP, A.; SILLAT, T.; SAAT, R.; KASAK, L.; TAMMISTE, I.; KOGERMAN, P.; KALKKINEN, N.; SIIGUR, J. A novel metalloprotease from Vipera lebetina venom induces human endothelial cell apoptosis. Toxicon, v. 46, p. 46-61, 2005.

WANG, W. J.; HUANG, T. F. Purification and characterization of a novel metalloproteinase acurhagin, from Agkistrodon acutus venom. Thromb. Haemost., v. 87 p. 641-50, 2002.

WANG, W.; SHIH, C.; HUANG, T. A novel P-I class metalloproteinase with broad substratecleaving activity, agkislysin, from Agkistrodon acutus venom. Biochem. Biophys. Res. Commun. v. 324, p. 224-230, 2004.

WARD, C. M.; ANDREWS, R. K.; SMITH, A. I.; BERNT, M. C. Mocarhagin, a novel cobra venom metalloproteinase, cleaves the platelet von Willebrand factor receptor glycoprotein Ib alpha. Identification of the sulphated tyrosine/anionic sequence Tyr-276-Glu282 of glycoprotein Ib alpha as a binding site for Von Willebrand factor and alpha thrombin. Biochemistry, v. 35, p. 4929-4938, 1996.

WARREL, D. A. Clinical toxicology of snakebite in Asia. In: MEIER, J.; WHITE, J. (Ed.). Handbook of clinical toxicology of animal venoms and poisons. Boca Raton, Florida: CRC Press, 1995. p. 493-594.

WARRELL, D. A. Clinical features of envenoming from snake bites. In: BON, C.; GOYFFON, M. (Ed.). Envenoming and their treatments. Lyon: Fondation Marcel Mérieux, 1995. p. 63-76.

WATANABE, L.; SHANNON, J. D.; VALENTE, R. H.; RUCAVADO, A.; ALAPEGIRÓN, A.; KAMIGUTI, A. S.; THEAKSTON, R. D.; FOX, J. W.; GUTIÉRREZ, J. M.; ARNI, R. K. Amino acid sequence and crystal structure of BaP1, a metalloproteinase from Bothrops asper snake venom that exerts multiple tissue-damaging activities. Protein Sci., v. 12, 2273-2281, 2003.

WHITE, J. Snake venoms and coagulopathy. Toxicon, v. 45, p. 951-967, 2005. Review. 
WIJEYEWICKREMA, L. C.; BERNDT, M. C.; ANDREWS, R. K. Snake venom probes of platelet adhesion receptors and their ligands. Toxicon, v. 45, p. 1051-1061, 2005. Review.

WILLIS, T. W.; TU, A. T. Purification and biochemical characterization of atroxase, a nonhemorrhagic fibrinolytic protease from western diamondback rattlesnake venom. Biochemistry, v.27, p. 4769-4777, 1988.

WU, W. B.; HUANG, T. F. Activation of MMP-2, cleavage of matrix proteins, and adherens junctions during a snake venom metalloproteinase-induced endothelial cell apoptosis. Exp. Cell. Res., v. 288, p. 143-157.

WU, W. B.; PENG, H. C.; HUANG, T. F. Crotalin, a vWF and GP Ib cleaving metalloproteinase from venom of Crotalus atrox. Thromb. Haemost., v. 86, p. 150-1511, 2001.

YOU, W. K.; SEO, H. J.; CHUNG, K.; KIM, D. A novel metalloproteinase from Cloydius halys venom induces endothelial cell apoptosis through its protease and disintegrin-like domains. J. Biochem., v. 134, p. 739-749, 2003.

YOU, W. K.; JANG, Y.; CHUNG, K.; JEON, O.; KIM, D. Functional roles of the two distinct domains of halysase, a snake venom metalloproteinase, to inhibit human platelet aggregation, Biochem. Biophys. Res. Commun., v. 339, p. 964-970, 2006.

ZAMIR, E.; GEIGER, B. Molecular complexity and dynamics cell-matrix adhesions. J. Cell Sci., v. 114, p. 3583-3590, 2001.

ZHOU, Q.; DANGELMAIER, C.; SMITH, J. B. The hemorrhagin catrocollastatin inhibits collagen-induced platelet aggregation by binding to collagen via its disintegrin-like domain, Biochem. Biophys. Res. Commun., v. 219, p. 720-726, 1996.

ZIGRINO, P.; KAMIGUTI, A. S.; EBLE, J.; DRESCHER, C. NISCHT, R.; FOX, J. W.; $\mathrm{MAUCH}, \mathrm{C}$. The reprolysin jararhagin, a snake venom metalloproteinase, functions as fibrillar collagen agonist involved in fibroblast adhesion and signaling. J. Biol. Chem., v. 277, p. 277, 40528-40535, 2002. 